\title{
Spain: Vulnerabilities of Private Sector Balance Sheets and Risks to the Financial Sector Technical Notes
}

This paper was prepared based on the information available at the time it was completed on May 2012. The views expressed in this document are those of the staff team and do not necessarily reflect the views of the government of Spain or the Executive Board of the IMF.

The policy of publication of staff reports and other documents by the IMF allows for the deletion of market-sensitive information.

Copies of this report are available to the public from

International Monetary Fund $\bullet$ Publication Services

700 19th Street, N.W. • Washington, D.C. 20431

Telephone: (202) 623-7430 • Telefax: (202) 623-7201

E-mail: publications@imf.org •Internet: http://www.imf.org

\section{International Monetary Fund \\ Washington, D.C.}


FINANCIAL SECTOR ASSESSMENT PROGRAM UPDATE

\section{SPAIN}

Vulnerabilities of Private Sector Balance SheEts AND RISKS TO THE FINANCIAL SECTOR

TECHNICAL NOTE

MAY 2012 


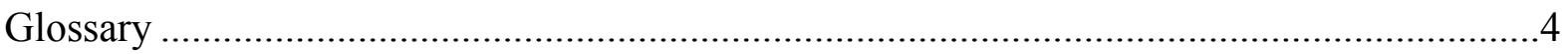

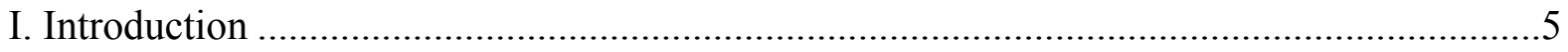

II. Household and Financial Sector Linkages .................................................................5

A. Developments During and After the Crisis.......................................................

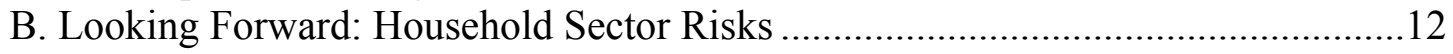

C. Sensitivity Analysis: Household Balance Sheets .............................................. 14

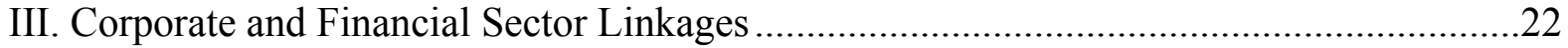

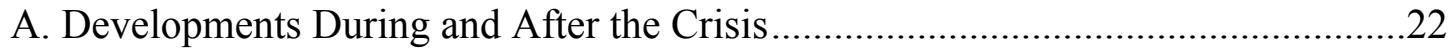

B. Contingent Claims Analysis of the Corporate Sector .........................................24

C. Sensitivity Analysis of the Corporate Sector .................................................25

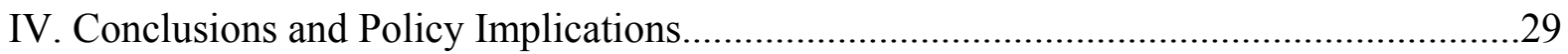

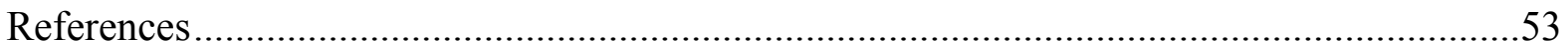

Tables

1. Selected Countries: Household Debt .............................................................................. 7

2. Comparisons of Shocks for the Sensitivity Analysis of Households Indebtedness............16

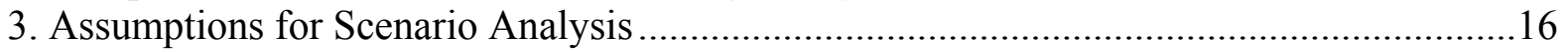

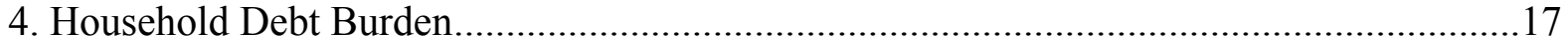

5. Sensitivity Analysis of Indebted Households ........................................................ 20

6. Scenario Analysis of Indebted Households .............................................................22

7. Bankrupt Companies by Main Economic Activity ...................................................25

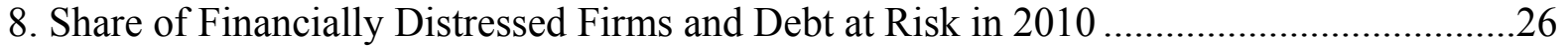

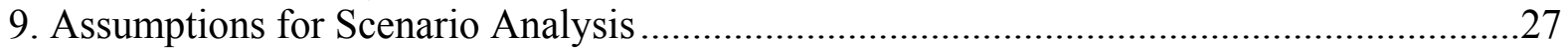

10. Sensitivity Analysis on the Spanish Nonfinancial Corporate Sector..............................28

11. Scenario Analysis on the Spanish Nonfinancial Corporate Sector ................................29

Figures

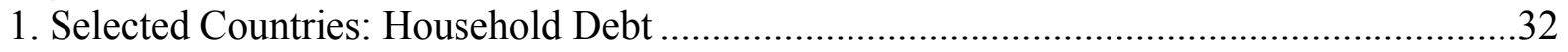

2. Credit and Housing Prices ........................................................................................32

3. Estimated Breakdown of Loans to Households by Income Category of the Borrower.......33

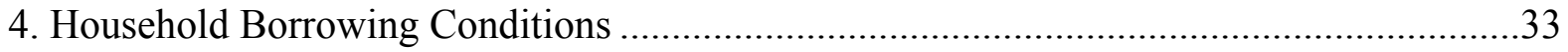

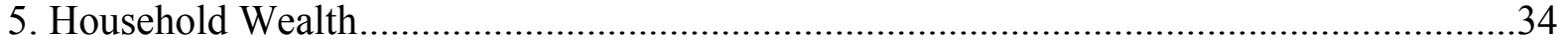

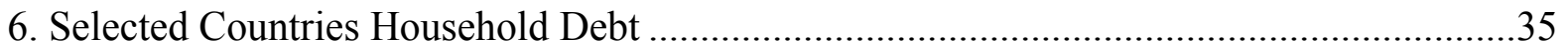

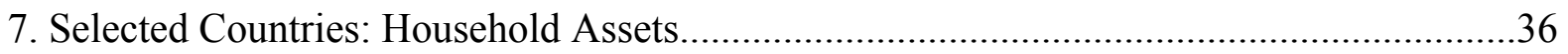

8. Selected Countries: Household Wealth .......................................................................36

9. Selected Countries: Young Adults Living with Their Parents..........................................37

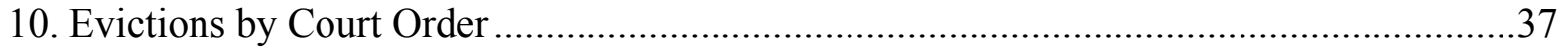

11. New Mortgage Loans and Mortgage Modifications .....................................................38

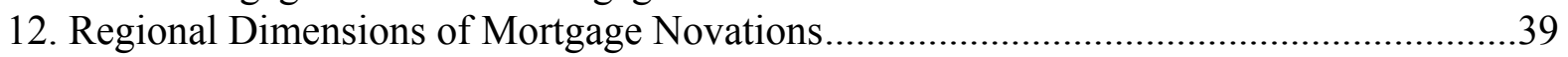

13. New Mortgage/Property Sales ......................................................................... 40 


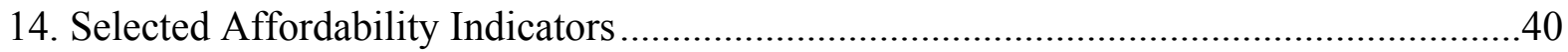

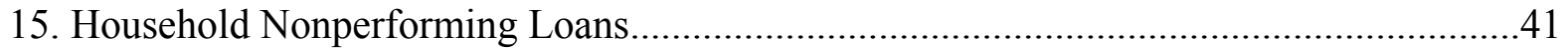

16. Household Balance Sheet Development, 2000-11 ..................................................42

17. Distribution of Debt, Real Assets, and Financial Assets Held by Indebted Households...43

18. Sensitivity Analysis of Indebted Households, 2008 ......................................................4

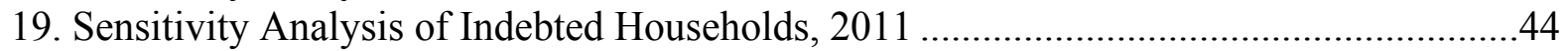

20. Selected Countries: Long-Term Unemployment ..............................................................4

21. Selected Countries: Nonfinancial Corporate Sector Debt ……………………................45

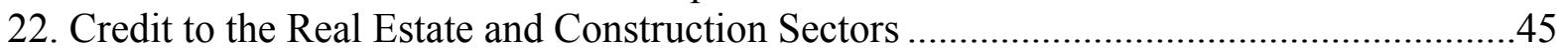

23. Financial Ratios by Sectors, Listed Companies..............................................................46

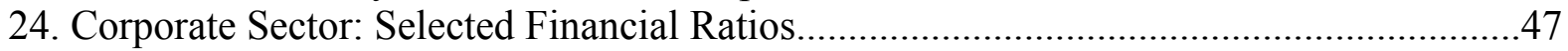

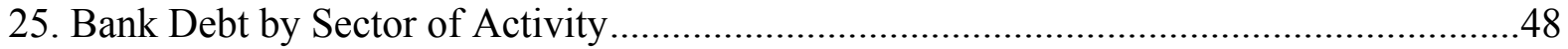

26. Adjustment of Credit to Real Estate and Construction.....................................................48

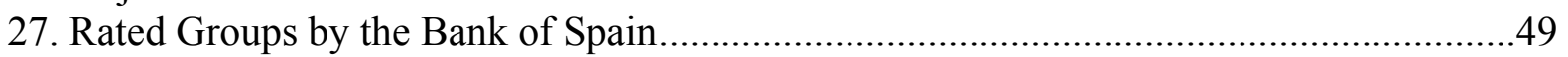

28. Default Risks of the Spanish Nonfinancial Corporates ....................................................50

29. Contingent Claims Analysis of the Spanish Nonfinancial Corporate Sector ....................50

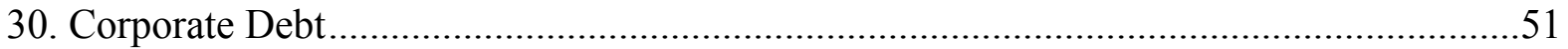

31. Sensitivity Analysis of the Spanish Nonfinancial Corporate Sector .................................52

Boxes

1. Measures to Protect Low Income and Distressed Borrowers ...........................................13

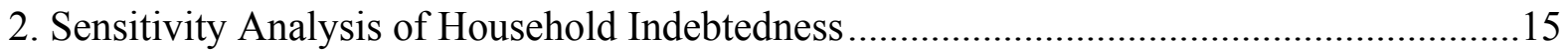

3. Contingent Claims Analysis of the Spanish Corporate Sector ...........................................24

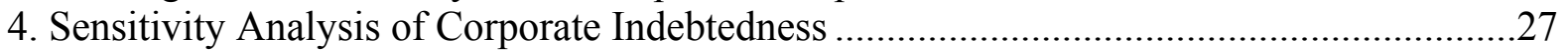

Appendices

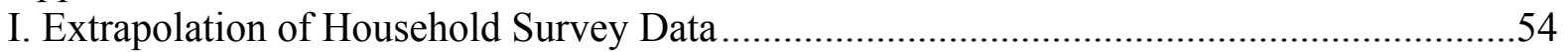

II. Household Debt Restructuring in Selected Countries.........................................................5 


\section{GLOSSARY}

$\begin{array}{ll}\text { BdE } & \text { Banco de España } \\ \text { IMF } & \text { International Monetary Fund } \\ \text { INE } & \text { Instituto Nacional de Estadística } \\ \text { GDP } & \text { Gross Domestic Product } \\ \text { LGD } & \text { Loss given defaults } \\ \text { SMEs } & \text { Small and medium-sized enterprises } \\ \text { NFCs } & \text { Non Financial Corporations } \\ \text { CCA } & \text { Contingent Claims Analysis }\end{array}$




\section{INTRODUCTION ${ }^{1}$}

1. This technical note assesses the vulnerabilities of household and corporate sector balance sheets and quantifies the potential impacts from macroeconomic shocks using sensitivity and contingent claims analyses (CCA). It takes a different approach than the stress tests used in this FSAP by assessing the soundness of the balance sheets of the main borrowers of the Spanish banking system, households, and the nonfinancial corporate sector. It relies on various sources of information, including aggregate statistics and more granular information from household surveys, and individual corporate balance sheet databases.

2. The context is that of high levels of debt but mitigated by country specific factors (in the case of household debt, high levels of wealth, a well developed full recourse system, family solidarity, social safety nets and lender forbearance for distressed households). The analysis applies the same magnitude of shocks as those of the bank stress testing exercise. It finds that the household's financial positions have weakened. The sensitivity analysis carried out for the Spanish households show that households are most vulnerable to rising interest rate and weaker economic activity, where the impacts of the shocks are most severe for borrowers among the poor and the young.

3. The Spanish nonfinancial corporate sector is highly indebted, largely as a result of the housing and construction boom. It remains vulnerable and the credit risk in the Spanish corporate sector is expected to increase further. The sensitivity analysis shows that the number of vulnerable firms increase significantly with macroeconomic shocks. More defaults are expected among most vulnerable sectors, including construction and real estate.

\section{Household AND FinANCIAL SECTOR LinkageS}

\section{A. Developments During and After the Crisis}

4. The housing boom has left Spain with relatively high household debt compared to the euro area. The United Kingdom, the Netherlands, Denmark, Sweden and Portugal have all higher household debt to income ratios than in Spain (Figure 1). However, Spain's household debt to income ratio has significantly diverged from the average of the euro area since 2001. Housing and leverage have also been moving in tandem during the boom. This is reflected both in the increased lending to construction and real estate activities and in the strong co-movement of housing prices and credit (Figure 2). Gimeno and Martinez-Carrascal (2006) show that house prices and mortgages in Spain are interdependent in the long run: loans for house purchases depend positively on house prices, while house prices adjust when this credit aggregate departs from the level implied by its long run determinants. In the short

\footnotetext{
${ }^{1}$ Prepared by Jerome Vacher and Piyaporn Sodsriwiboon (both EUR). The authors would like to thank Marta Ruiz-Arranz for sharing computer programs and helpful suggestions, and Dale Gray for useful advice on the CCA.
} 
run, the two variables have a positive contemporaneous impact on each other, indicating the existence of mutually reinforcing cycles in both variables. ${ }^{2}$

5. Debt burdens are concentrated across households (Figure 3). Household debt in Spain is largely concentrated in mortgages ( 80 percent) and the share of households with mortgages in Spain is similar to France and Germany. Still, those households who have debt tend to be more leveraged. Another country with high home ownership, Italy, has also the lowest percentage of households with mortgages in the euro area and low leverage, about half that of Spain (Table 1). ${ }^{3}$ Beyond these aggregate differences, and despite the fact that more affluent households represent a larger share of aggregate debt, Spain's median household debt to income ratio is significantly higher in poorer (as measured by wealth) and younger households. This is notably due to increased home ownership in the boom years (e.g., the share of households in the two lowest income deciles owning their primary residences increased from 71 percent to 78 percent between 2005 and 2009). Debt service has increased by 2 percentage points during that period, but more so for the young (4 percentage points). The prevalence of debt is also proportionately more important in households that are not employed. It is also noteworthy that the prevalence of mortgages and the median debt to income ratio among the young (less than 35) is higher in Spain than in the United States (which overall has a similar median debt to income ratio but a higher prevalence of debt). ${ }^{4}$

\section{With debt service on the high side, low interest rates in the downturn have} alleviated tensions on household budgets. For households with debt, the median debt service was 19 percent in 2008, very similar to the median in Italy or the United States - but at a much higher 35.5 percent at the $75^{\text {th }}$ percentile. 90 percent of lending to households in Spain is at variable rates, and 88 percent is secured (as mortgages prevail and are collateralized). ${ }^{5}$ Mortgages more specifically are at 98 percent variable rates, and adjust in line with the Euribor 12 months. Though this is a clear factor of risk and a source for potential adverse shocks, the lower policy rates since 2008 have clearly helped in alleviating tensions on household balance sheets (Figure 4). With declining profitability and increasing funding costs, banks have not fully passed through the decline in Euribor 12 month rates and

\footnotetext{
2 The average maturity of mortgages at inception in Spain has increased substantially during that period, from 12 years in 1990, to 22 years in 2000, and 28 years at the peak of 2007 . The average maturity of the existing stock of mortgages is currently estimated at 10-12 years. Prepayment rates which were high during the boom (about 15 percent) and are estimated to have fallen to about 3.5 percent in 2011.

${ }^{3}$ The data comes from household finance surveys prepared by the Spanish and Italian central banks. Central banks and statistical offices of the euro area are engaged in an effort to coordinate and harmonize household finance surveys under the leadership of the European Central Bank (ECB) (http://www.ecb.int/home/html/researcher hfcn.en.html). Few surveys are published, and the level of dissemination is among the highest in Spain and Italy.

${ }^{4}$ The median debt to income ratio is twice lower in the United States than in Spain for households below 35 years of age (90.7 percent vs. 217.4 percent in Spain), but is higher for all other age brackets.

${ }^{5}$ In 2005 , the respective shares were 76.4 and 75.5 percent of total loans to households.
} 
have also increased their fees. However, the incomplete pass-through matters only for households that take on new borrowing in limited numbers since new mortgages have declined substantially from peak. The decline in Euribor rates matters for the current stock of mortgages.

Table 1. Selected Countries: Household Debt

\begin{tabular}{|c|c|c|c|c|c|c|c|c|c|}
\hline & \multicolumn{3}{|c|}{ Median Debt to Income } & \multicolumn{3}{|c|}{ Percentage with any Type of Debt } & \multicolumn{3}{|c|}{ Percentage with Mortgages } \\
\hline & Spain & US & Italy & Spain & Italy & US & Spain & Italy & US \\
\hline Total households & 104.7 & 111.4 & 45.3 & 50.1 & 27.8 & 77.5 & 26.3 & 12.6 & 49.4 \\
\hline Male (head of household) & & & 49.1 & & 30.3 & & & 14.2 & \\
\hline Female (head of household) & & & 39.3 & & 22.1 & & & 9.0 & \\
\hline \multicolumn{10}{|c|}{ By household net wealth (percentile) } \\
\hline Less than 25 & 139.4 & $\ldots$ & 26.1 & 50.1 & 26.4 & 69.5 & 21.8 & 2.6 & 16.1 \\
\hline $25-50$ & 151.7 & $\ldots$ & 68.1 & 53.5 & 27.7 & 88.2 & 36.4 & 14.6 & 58.1 \\
\hline $50-75$ & 87.0 & $\ldots$ & 74.7 & 47.5 & 31.2 & 78.8 & 28.3 & 18.5 & 63.7 \\
\hline $75-90$ & 61.8 & $\ldots$ & 32.9 & 51.3 & 25.8 & 76.0 & 18.3 & 11.8 & 63.4 \\
\hline $90-100$ & 98.6 & $\cdots$ & 45.1 & 46.3 & 27.8 & 70.2 & 19.3 & 15.5 & 58.4 \\
\hline \multicolumn{10}{|l|}{ By age (head of household) } \\
\hline Less than 35 & 217.4 & 90.7 & 58.3 & 68.6 & 36.8 & 84.6 & 45.6 & 15.4 & 40.0 \\
\hline $35-44$ & 142.7 & 145.4 & 78.0 & 72.3 & 42.0 & 87.7 & 51.4 & 22.8 & 60.2 \\
\hline $45-54$ & 89.9 & 121.1 & 42.2 & 60.0 & 39.3 & 86.6 & 27.9 & 18.7 & 64.2 \\
\hline $55-64$ & 41.0 & 100.0 & 28.8 & 48.5 & 24.8 & 77.7 & 13.3 & 8.9 & 54.2 \\
\hline $65-741 /$ & 55.3 & 84.6 & 16.5 & 22.9 & 8.6 & 62.1 & 4.6 & 2.3 & 41.6 \\
\hline More than 74 & 18.5 & 44.1 & & 9.9 & & 35.0 & 1.9 & & 15.1 \\
\hline Employed & 121.3 & $\ldots$ & 49.1 & 68.4 & 36.8 & 86.6 & 41.8 & 18.1 & 57.9 \\
\hline Not employed & 100.9 & $\ldots$ & 22.0 & 36.7 & 11.8 & 55.2 & 15.8 & 3.7 & 31.0 \\
\hline
\end{tabular}

Sources: Banco de Espana; Banca d'Italia; and US Federal Reserve.

1/ Data for Italy are more than 65.

\section{The capacity to bear these debt burdens has also been supported by the high} levels of wealth in Spain, albeit largely concentrated in real estate (Figure 5). The main mitigating factor to the high household debt is the particularly high level of household wealth in Spain (estimated at six times GDP), and mainly concentrated in real estate -87 percent of their household wealth vs. an average of 60 percent in the euro area (Figure 6). This reflects a high homeownership ratio ( 82 percent), a significant degree of ownership of secondary houses, and overall a strong preference for housing as a saving instrument. Among the young, primary residence ownership is also more prevalent compared to other countries. As a consequence of a relatively high wealth, debt-to-asset ratios are low compared to other countries.

8. Besides housing, Spanish household wealth is concentrated in traditional saving products. In contrast to the United States, Spanish households hold relatively little equities and investment funds (Figure 7). Pension funds also play a limited role in household portfolios (as opposed to the United States where the role of government sponsored retirement systems is limited). This explains in part the relative underdevelopment of the asset management industry in Spain, with investment products largely sold through bank networks, and households placing their financial wealth mostly in deposits. Household deposits have been declining gradually since the summer of 2011, but the respective 
contributions of economic difficulties on household budgets and the competition of other products (commercial paper issued by banks - or "pagares"- and T bills especially in the fall of 2011) are difficult to assess. There are also signs that the competition for deposits has abated as banks are deleveraging and the LTRO has diminished pressures on bank funding in the first half of 2012.

9. Wealth is also relatively spread out across income categories. Although income inequality is relatively high in Spain compared to the rest of Europe, wealth dispersion is low. Wealth inequality is low compared to the United States and is also within each subset of the population, notably for the employed (Figure 8). This lower inequality is also attributable to a high degree of home ownership, starting with the young.

10. The share of households with negative housing equity-whereby the outstanding mortgage amount is higher than the market value of the dwelling-is estimated to be relatively low, but is masked by the limited geographical mobility of households. In contrast to the United States, the share of households with negative equity is not as relevant for financial stability purposes due to differences in mortgage markets (full recourse system in Spain and less strategic defaults). While highly dependent on the valuation made for the LTV ratios, banks have been overall quite conservative in granting loans usually at low LTVs, except perhaps in the last years of the boom (2005-06). Regional mobility is particularly low in Spain, especially compared to the United States where households move about twice as much during a lifetime. This might explain why despite pockets of negative equity, household distress is limited as the need to realize losses is less. As a consequence, the housing market is also relatively less fluid, with an even more limited amount of transactions in a downturn, slowing the necessary adjustment in prices.

11. Family solidarity, social safety nets, and the weight of the grey economy are also important components alleviating the pressure from economic distress on household budgets. The role of family solidarity is particularly notable for younger households, who tend to live with their parents longer than elsewhere, thereby potentially mitigating the effect of unemployment (Figure 9). Interestingly though, this share has continued to decline during the crisis, perhaps as part of a longer term trend. This solidarity is multidimensional and for instance a high share of family members, even when they have left the household, reside very close to one another. An additional factor is the importance of social safety nets and in particular unemployment benefits. The grey economy (estimated at between 17 percent and 23 percent of GDP depending on the studies) might also mitigate the adverse impact of unemployment on default rates (for example on consumer credit). The government has been taking a series of measures to diminish its size, notably through measures against tax evasion and limitations to the payments in cash. 


\section{Lender restructuring in Spain}

\section{The mortgage market is characterized by strict full recourse and a low level of} defaults. Mortgages in Spain, as in other countries in continental Europe (e.g., France) are full recourse, offering great protection to the lender. ${ }^{6}$ This means that banks have the possibility to recover the full value of the loan, but also fees and penalties. The process of recovery can be long if the courts are involved however. According to the BdE, the average time it takes to realize collateral is 2 years. The first step is the adjudication (for which only estimates are available on the units repossessed by banks over time), and the second step is the eviction (data compiled by the judicial system). For the latter, despite a worsening of the economic situation, anecdotal evidence suggests that banks have been avoiding evictions to the extent possible in recent months (Figure 10). In the more unusual event of a payment in kind ("dacion en pago") at the discretion of the institution if no other viable solution has been found, the average recovery period would be less than a year. Nonperforming loan rates for mortgages are low, after an initial leap at the beginning of the crisis (consistent with the experience of other countries, but still low considering the depth and length of the downturn and associated rapid increase in unemployment). According to the BdE, the typical recovery value for residential mortgages in case of default is 85.5 percent (according to regulatory LGD downturn available data).

13. The statistical system captures part of the refinancings. The INE regularly publishes data on mortgage novations, debtor and creditor subrogations. Mortgage statistics count the total number of changes in mortgages registered in the Property Registry:

- $\quad$ Lender mortgage subrogation is the process by which the mortgage lender takes over from another institution a loan and modifies either the interest rate originally agreed, or extends the term of the loan or both. This is quite common when competition increases and borrowers "shop around" for better conditions (taking into account that changing banks still entails fixed costs).

- $\quad$ Borrower mortgage subrogation is a change of borrower(s) of the mortgaged property without a change of the lender - for instance, when a person or entity purchases a house that has a mortgage (in this case the buyer is subrogated to the mortgage of the seller).

- A novation change is when a modification of the terms of the mortgage occurs within the same financial institution. Novation occurs when the debtor makes a pact with the financial institution under new conditions. These new conditions may be related to the interest rate, the outstanding amount, the repayment period, or even to changes related to other loan holders (suppression of one of them, etc.).

\footnotetext{
${ }^{6}$ The mortgage law actually already includes the possibility of limited recourse ("dacion en pago"), but the general practice has been of full recourse. One bank (Bankinter) has recently advertised limited recourse loans for a targeted clientele.
} 


\section{The statistic does not provide data on mortgages in terms of the amount of} borrowed capital, only on the number of changes. For the moment, within novations it is also not possible to quantify the changes in other conditions of the loan other than interest rates, such as the increase in borrowed capital or the duration of the mortgage. Another limitation is that some changes such as implementing a grace period do not necessarily require to be registered at the property registry (it is at the discretion of the borrower who may want increased security, and it affects mostly the amortization plan proposed by the bank). Anecdotal evidence suggest that the most common practice among banks is an increase in the grace period, especially in the most recent period. Extensions of the maturity of the loan (especially at the beginning of the crisis) and changes in interest rates (e.g., through lower fees and spreads over the reference rate) are also used, but to a lesser extent.

\section{Mortgage modifications have peaked in 2009, and were closely linked with} economic conditions. A first wave of mortgage modifications took place in 2008/2009 as the economic situation quickly deteriorated, construction came to a halt and unemployment increased sharply (Figure 11). Anecdotal evidence points to a first wave of modifications, as the most vulnerable on the labor market were hit first (at the same time there was a first wave of defaults, for example among immigrant workers who often borrowed towards the end of the boom years). Data on mortgage modifications by regions and provinces (Figure 12), show a strong correlation with foreclosures, and to a lesser extent with job losses, notably in the first phase of the crisis (there are regions where corporate, household, and bank distress are concentrated and reinforce each other). Novations were also triggered by the decline in interest rates, and the few households with older vintages of mortgages not indexed to Euribor, who switched to variable rate mortgages at this time. Overall, the number of novations is high, though difficult to estimate and compare across countries. ${ }^{7}$ Though a possibility, there is no strong evidence that new mortgages have been used to refinance other debts (e.g., consumer) - if anything the proportion of new mortgages to total sales has declined pointing also to lower leverage in real estate transactions - though this could have also occurred through mortgage modifications (Figure 13).

\section{The BdE has sought to contain lender restructuring through regulation and its} supervisory practices. ${ }^{8}$ For retail loans, the BdE reviews the general policy of the institutions and also samples of operations. For retail mortgage operations, BdE has also set a number of guidelines and requirements for reclassification:

- $\quad$ For residential mortgages, payments should not be due more than six months, the postponement period should be a maximum of 18 months, and minimum payments

\footnotetext{
${ }^{7}$ The number of novations cumulative since the beginning of the crisis (about 1.5 million) is pretty high compared to what the outstanding number of mortgages can be estimated at (approximately 11 million new mortgages are $€ 112,000$ on average, and have declined in size since the beginning of the crisis).

${ }^{8}$ Anecdotal evidence gathered from banks suggests that what banks consider as refinanced portfolio represent on average about $4 \frac{1}{2}$ percent of their total loan book. Most of which is to real estate developers and SMEs-for the most part classified as substandard and doubtful — and about $1 / 4$ of this refinanced portfolio is mortgages.
} 
should be made during the 18-month period. Interest income is only recognized when paid- so that, in principle, if the refinanced loan meets these requirements, it may qualify as a sub-standard loan and be subject to a cautionary provision of 5 percent (if the LTV is below 80 percent) or 10 percent (if the LTV is above 80 percent), unless it was qualified previously as doubtful. Once the postponement period is over, the exposure can be upgraded subject to meeting 3 monthly payments.

- $\quad$ For retail consumer operations, some guidelines are also in place. Subject to meeting the requirements above, the loan may qualify as sub-standard with a 10 percent cautionary provision, unless it was qualified previously as doubtful. In this case, the exposure can be upgraded only when the debtor meets 12 -monthly payments after the end of the postponement period.

However comprehensive as it may be, this still leaves some room for an array of refinancings, e.g., through an increase of the maturity of the loan or grace period, that might not be fully reflected in substandard or doubtful loans. For example, it appears that a loan that is still performing, but with difficulties looming because of the situation of the borrower, can benefit from a grace period, and will still be classified as normal provided that the grace period applies only to the capital.

\section{A number of individual banks have taken a proactive approach and advertised} specific programs to ease mortgage payments. It also seems that a significant number of initiatives taken by banks were not necessarily advertised. Recent examples of programs put in place by banks include:

- $\quad$ Santander has put in place a program in August 2011 of capital grace period of three years, for unmployed customers or who have suffered a fall in earnings in excess of 25 percent. Customers have the possibility of extending the maturity of their mortgage to compensate for the grace period. This program has benefited 9,820 households for a total amount of debt of 1.6 billion, for which the average debt service has declined by 48 percent.

- CatalunyaCaixa implemented in 2008 a nonrecourse (for 6500 households) and rental program (for 1,850 households). It has also implemented programs to reduce debt service to selected households (12,000 during 2011). One of the latter includes a loan to refinance debt coming due for two years. The bank also implements reductions in principal for a limited period of time.

18. This has been recently complemented by a government plan for low income and distressed borrowers (Box 1). The plan was motivated by increasing calls to alleviate the pressure on low income borrowers that might be trapped in difficult foreclosure processes. It also complements previous efforts to improve the process for auctioning assets foreclosed from defaulting households (the judicial auction process was not transparent, leaving the lender in position to purchase the asset at a low price, and leaving borrowers with the 
difference still due), as well as previous restructuring programs for unemployed mortgage borrowers sponsored by the government in 2009, but which had limited take up.

\section{B. Looking Forward: Household Sector Risks}

\section{A continuation of the slide in housing prices will weigh on households balance} sheets, and housing wealth in particular. Prices have fallen less in Spain than in Ireland and the United States, though similar to the United Kingdom (which had less expansion in its population, housing stock and construction activities). ${ }^{9}$ The adjustment seems is not complete compared to estimates of the initial degree of overshooting, with a 27 percent decline in real terms, close to the average of housing busts in the euro area, but likely still with more to go in nominal terms, in particular considering that housing supply dynamics (inventories of unsold units) are not appropriately captures by overvaluation models. Price indices suggest that the fall in prices is accelerating. Affordability indicators have improved, notably as mortgage rates went down, but not enough to stimulate demand (Figure 14). ${ }^{10}$ The mortgage interest deduction from income tax temporarily limited in 2011, has been reinstated (retroactively and at a high cost), but is unlikely to improve demand and affordability for new mortgages. $^{11}$

\section{Supply will continue to weigh heavily on housing prices with the stock of unsold} units taking several years to clear. The lowest estimates of the stock of unsold units are at close to 700000 units, with considerable regional variations but with a downward adjustment that has only started at the end of 2010. These only include newly completed units, and do not fully include units repossessed by financial institutions, unsold secondary market houses, or unfinished units. ${ }^{12}$ Long-run sustainable demand and updated in light of revised demographic projections, points to a sustainable demand of about 300000 units/year (IMF, 2011b). In light of this and current housing starts and completions, it would take about four years to clear the inventory (e.g., taking into account the fact that, for technical reasons, the housing inventory cannot go down to zero). The financial sector reform might push banks to sell their repossessed housing units.

\footnotetext{
${ }^{9}$ See IMF (2011b).

${ }^{10}$ It should be noted that house price to income ratios are not directly comparable across countries, both because of differences in the underlying data and differences in preferences and equilibrium values of these ratios over the long run.

11 The mortgage interest deduction prevalent until January 2011 included a tax credit of 15 percent of the principal and interest and capped at €9000. The mortgage interest deduction was limited in 2011, but reinstated in 2012 with retroactive effect to 2011. The house price-to-rent ratio remains higher than in other countries. Rents (on new rentals) have adjusted downwards with declines from peak of between 10 percent and 26 percent in the three largest cities (Madrid, Barcelona and Valencia).

${ }^{12}$ Units repossessed by financial institutions are estimated at between 100 and 200000 units. Those actively put for sale on the market are estimated at about a quarter of the total stock.
} 


\section{Box 1. Measures to Protect Low Income and Distressed Borrowers}

Royal Decree Law 6/2012 was approved on March 9, 2012 and seeks to put in place a multi pronged approach to distress for low income households and avoid socially costly foreclosures and evictions. It includes the following three steps for the qualifying households: (i) a grace period, reduction of interest rate and extension of the maturity; (ii) if (i) is not enough, a debt reduction at the discretion of lenders; and (iii) if (i) and (ii) do not work, the mortgage can be paid for in its entirety through foreclosure ("dacion en pago") but the borrower is allowed to rent the house for a period of 2 years.

The definition of the target population of households is restrictive and should limit the application of the measures to those most in need. The household must have no income from an economic activity (i.e., it can still perceive social subsidies and unemployment benefits) and a debt service above 60 percent of income, far above the median. According to the 2008 household survey data, households with debt service to income ratio above 60 represented about 8 percent of total households. Households with a debt service to income above 60 and unemployed were about 1.1 percent of total households. These numbers would increase significantly during 2009-11. Extrapolating from the survey data based on developments in aggregate macroeconomic variables, and taking into account an increase in unemployment, a decrease in household income, and interest payments, the share of households with debt service to income ratio above 60 could be estimated at 17.8 percent of total indebted households in 2011 (or an estimated 9 percent of total households). Of which households with debt service to income above 60 and unemployed would be about 5 percent of total households. This might overestimate the share of households in this category, as the decree considers only debt service to income ratio of 60 percent for mortgages excluding other types of debt. There are also restrictions on the dwellings considered (depending on price and location), further limiting the target population.

So far, a large number of institutions have agreed to abide by the voluntary code of conduct. The main incentive for banks to participate was reputational. Santander, CatalunyaCaixa were the first to indicate their participation as well as all the members of CECA; the list of participants ( 88 institutions) has been published on April 12, and covers more than 95 percent of the mortgage market. A monitoring commission will publish a report on the implementation of the measure every six months. From a financial stability perspective, the impact of the measure does not seem to be large on banks themselves, though an ex ante analysis is difficult as the information systems in place individual institutions do not precisely capture or match the extent of the targeted population. The measures do not seem to have uncovered tail risks that banks have in their balance sheet, as to a large extent banks were already engaged in similar measures already, on a case by case basis. The decree itself does not introduce changes in bank regulation and in case of the restructurings described below, the loans would have to be reclassified as at least substandard, if not doubtful.

\section{Continued increases in unemployment and a pick-up in borrowing rates are}

further risks to household balance sheets. Nonperforming loans have started to increase again in 2011 after the initial jump of the 2008-09 crisis, and point to renewed vulnerabilities in household balance sheets, in the context of what is expected to be a double dip recession (Figure 15). This increase is most likely due to the deterioration in economic activity and in particular the increase in unemployment, notably in the second half of 2011 (Figure 16). The increase in unemployment experienced at this stage of the crisis might affect different types of households, with potentially a higher proportion of mortgage holders among those (the first affected in 2008-2009 were the young and immigrants, both less likely to hold a mortgage). At the same time, though Euribor rates are low and have declined at the beginning of 2012, the increase in rates in 2011 (more pronounced if effective borrowing rates are taken into account) might have contributed to the renewed increase in nonperforming loans. 


\section{Sensitivity Analysis: Household Balance Sheets}

\section{This section analyzes the risks to the Spanish financial stability arising from}

household indebtedness. The analysis expands the use of micro-level data to assess household vulnerabilities distinguishing between indebted and non-indebted households as well as accounting for the allocation of debt, debt service burden, households' income and assets. The analysis is based on the sensitivity analysis of household indebtedness (Box 2) to quantify potential debt at risk in the banking sector, given various macroeconomic shocks that could affect the households' debt servicing ability and financial positions.

\section{Baseline}

23. The share of financially stressed households and debt at risk appears significant, though debt was largely covered by household assets (Table 4). According to the 2008 household survey, 161/2 percent of indebted households were financially distressed-i.e., with a ratio of debt payments to income above 40 percent. ${ }^{13}$ The debt-at-risk, or debt held by financially stressed households, was substantial at about 46 percent of total loans to households. With total loans to households of 80.9 percent of GDP, nearly half of this amount could come under financial strain. However, to a large extent, household debt is covered by household assets. The amount of debt held by vulnerable households that is not covered by real or financial assets (debt at risk) was only 1.1 percent of total loans to households or about 0.9 percent of GDP. ${ }^{14}$ It is important to note that household assets which are largely real estate related could have lost value during the crisis, even before the shocks are applied, and that real estate assets can be relatively illiquid in the presence of limited transactions. Therefore, the results appear relatively mild.

\section{The poor and the young presented the most vulnerable group among all}

households. The shares of vulnerable households and debt-at-risk were the largest among lower income groups, 40.9 percent and 81.8 percent for the household income group below the twentieth percentile. For the young, these shares were also very high, while the debt at risk was the highest. However, it is important to note that these households account for only a small fraction of total loans to households, only 2 percent of total loans to households for the lowest income group (Figure 17).

\footnotetext{
${ }^{13}$ It is important to note that the 2008 household survey data as used in this analysis may not be entirely coincide with the 2008 EFF published report, as the households' wealth weights of each household are not included in the calculation though this is comparable with other FSAPs and other central banks' household stress tests i.e. Riksbank (2009), OeNB (2010), World Bank (2010), UK FSAP (2011). Taking into account the weight of each household's wealth is more adequate however for a more representative coverage of the sector, with the share of debt at risk in each income group likely to be lower in simulations as a result.

${ }^{14}$ Household assets which are largely real estate related could have lost value during the crisis, even before the shocks are applied. Therefore, the results appear relatively mild.
} 


\section{Box 2. Sensitivity Analysis of Household Indebtedness}

The sensitivity analysis analyzes the vulnerabilities in the household sector and aims at identifying the potential impacts on financial stability, taking into account the allocation of debt, debt payment and income. Household's sensitivity analyses have recently been carried out by a number of central banks and international institutions (e.g., Riksbank (2009), OeNB (2010), World Bank (2010), IMF (2011a)), although the methodology could differ, depending on data availability and country-specific shocks.

The sensitivity analysis assumes that households are subject to various macroeconomic shocks. These include shocks from interest rates, income, unemployment and asset prices. The analysis assesses the changes in the share of vulnerable households. The analysis is based on the micro-level data from the BdE's 2008 Survey of Household Finances (EFF). The survey contains, for each individual household, real and financial assets, debts, debt service, income, labor market status, demographics and others. The sample includes 6,197 Spanish households.

A household is classified as vulnerable or so-called borrower-at-risk, when debt service is above a certain threshold. The debt service burden is measured by debt payments (interest payments plus redemptions) as a share of disposable income (DSI). The 40 percent threshold debt service burden is defined as in, for example, IMF(2011a) and Karasulu (2008). Alternative thresholds based on two standard deviations of the average debt service burden within each income group or stricter thresholds of 20 or 30 percent as in OeNB (2007) and World Bank (2010) are also tested but do not alter the conclusions. It has to be noted that although the 40 percent threshold is standard in the literature - making the results of this analysis comparable to other countries - there are a number of reasons why the threshold might be higher in Spain, including a high share of home ownership and household wealth. The use of shocks at the household level, not distinguishing between the situations of the different members of the household, may also introduce some upward bias in the simulations.

Debt-at-risk is defined as the share of total household debt held by vulnerable households.

The proportion of debt held by vulnerable households that is not covered by household's financial or real assets is then estimated. Specifically,

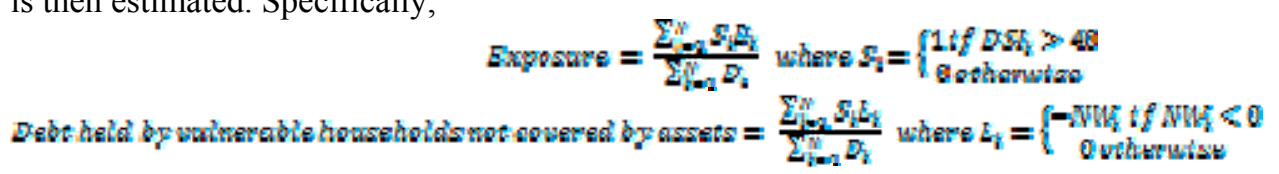

where $D_{i}$ is the debt of household i. $N W_{i}$ is the net worth of household i, or the sum of household real and financial assets deducted by total household debt.

Given the changes in households' financial situation, the tests would identify the changes in the proportion of vulnerable households as well as the changes of debt at risk. The sensitivity analysis considers the following shocks, taking place within a year:

1) Interest rate shock assumes an increase in interest rate of 100 and 200 basis points (the first being similar to the one applied in the FSAP's stress test, based on a more comprehensive macroeconomic scenario). The household's implied interest rate is calculated as a fraction of debt service payments in relation to household debt. This fraction of interest payment is determined based on the average maturity of mortgage debt, interest rate on mortgage, and increases in housing starts. An increase in interest rate is multiplied by the debt, and the above measures are recalculated.

2) Income shock assumes a decline in household income by 5,10 , and 20 percentage points uniformly across all households. These are large shocks but for the mildest of them refers to a situation where the wagesetting becomes very flexible and wage moderation takes place across the board.

3) Unemployment shock assumes an increase in unemployment rate by 1, 3 and 5 percent, where every employed persons are randomly selected to become unemployed. These unemployed households receive only unemployment benefits of about 70 percent of previous earnings, which corresponds to the average replacement rate in Spain. 


\section{Box 2. Sensitivity Analysis of Household Indebtedness (Concluded)}

4) Real estate price shock assumes a decline in house price by 10,20 and 30 percent. The shock directly affects the household's net worth.

Table 2. Comparisons of Shocks for the Sensitivity Analysis of Households Indebtedness

\begin{tabular}{lll}
\hline & Sources & Shock applied \\
\hline Interest rate shock & Riksbank(2009) & 6 percent increase \\
& World Bank (2010) & 3,5 and 6 percent increase \\
& OeNB (2010) & 1,2 and 3 percent increase \\
& $\operatorname{IMF}(2011 \mathrm{a})$ & 3 percent increase \\
\hline Income shock & $\operatorname{IMF}(2011 \mathrm{a})$ & 20 percent decline \\
\hline Unemployment shock & Riksbank(2009) & 6 percentage increase in level \\
& World Bank (2010) & 10 and 15 percent increase \\
& OeNB (2010) & 1,2 and 3 percent increase \\
\hline Real estate price shock $\operatorname{OeNB}(2010)$ & 10,20 and 30 percent decline \\
& $\operatorname{IMF(2011a)}$ & 20 percent decline \\
\hline
\end{tabular}

The scenario analysis applies the macroeconomic scenarios as in the banking sector's scenario analysis and combines the impact of shocks. This forward looking analysis applies the baseline macroeconomic projection for 2012 and 2013 onto the extrapolated survey data of 2011. Then, it analyzes the household's financial situations, should the economic situations deteriorate further.

Table 3. Assumptions for Scenario Analysis (In percent, otherwise indicated)

\begin{tabular}{|c|c|c|c|c|c|c|c|}
\hline & \multirow[b]{2}{*}{2011} & \multicolumn{2}{|c|}{ Baseline } & \multicolumn{4}{|c|}{ Adverse Scenario-BdE Adverse Scenario-IMF } \\
\hline & & 2012 & 2013 & 2012 & 2013 & 2012 & 2013 \\
\hline Real GDP & 0.7 & -1.7 & -0.3 & -2.5 & -0.7 & -4.1 & -1.7 \\
\hline Harmonized Index of Consumer Prices & 3.1 & 1.8 & 1.6 & 1.6 & 1.2 & 1.1 & 0.2 \\
\hline Gross Disposable Income 1/ & 0.4 & 0.2 & -1.3 & -0.3 & -2.4 & -1.3 & -4.6 \\
\hline Unemployment Rate & 21.6 & 23.8 & 23.5 & 24.2 & 24.5 & 25.0 & 26.6 \\
\hline Euribor, 12 months & 2.0 & 1.6 & 1.5 & 1.6 & 1.5 & 2.6 & 2.5 \\
\hline Housing Prices & -5.6 & -5.6 & -2.8 & -10.6 & -3.1 & -19.8 & -3.6 \\
\hline
\end{tabular}

Sources: BdE, and IMF Staff Calculations.

$1 /$ The growth of gross disposable income is based on a simple regression of real disposable income growth and real GDP

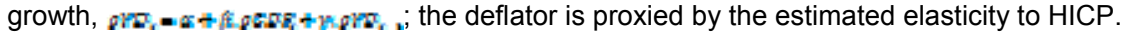

\section{The 2008 survey data is then extrapolated to 2011, replicating the developments}

of aggregate variables. Navigating through the global financial crisis and housing bust in Spain during 2008-11 had a significant impact on households' financial positions. As of 2011, housing prices declined by approximately 25 percent from peak, thus worsening households' net worth. The number of unemployed persons increased by 93 percent in 2011 , compared to that of 2008, while the unemployment rate doubled to about 21.6 percent in 2011, from 11.3 percent in 2008. Wages and household's disposable income were also adjusted. Gross disposable income declined by about 0.7 percent during 2008-11. Household debt remained relatively stable with only 0.5 percent decline from the peak in 2008 . To the 
extent possible, these changes were applied to the 2008 Spanish household survey to represent more recent situations (Appendix I).

Table 4. Spain: Household Debt Burden1/ (Indebted households in percent, otherwise indicated)

\begin{tabular}{|c|c|c|c|c|}
\hline & $\begin{array}{c}\text { Ratio of Debt Payment to } \\
\text { Household Income } \\
\text { (median) }\end{array}$ & $\begin{array}{l}\text { Share of Distressed } \\
\text { Household in Each } \\
\text { Income Group }\end{array}$ & $\begin{array}{l}\text { Share of Debt at } \\
\text { Risk in Each } \\
\text { Income Group }\end{array}$ & $\begin{array}{l}\text { Debt at Risk not } \\
\text { Covered by Household } \\
\text { Assets (in percent of } \\
\text { total household loans) }\end{array}$ \\
\hline \multicolumn{5}{|c|}{ Baseline Based on Household Survey 2008} \\
\hline All & 18.1 & 16.5 & 45.9 & 1.1 \\
\hline \multicolumn{5}{|l|}{ Income } \\
\hline$<20$ & 34.7 & 40.9 & 81.8 & 1.1 \\
\hline $20-40$ & 25.9 & 23.3 & 44.8 & 1.5 \\
\hline $40-60$ & 20.7 & 17.4 & 46.9 & 1.5 \\
\hline $60-80$ & 16.4 & 10.7 & 36.8 & 3.4 \\
\hline $80-90$ & 12.5 & 9.0 & 41.9 & 0.0 \\
\hline $90-100$ & 8.9 & 8.4 & 50.0 & 0.3 \\
\hline \multicolumn{5}{|c|}{ Age of household head } \\
\hline$<35$ & 23.4 & 20.0 & 38.3 & 4.1 \\
\hline $35-44$ & 21.9 & 18.8 & 35.2 & 2.9 \\
\hline $45-54$ & 17.2 & 13.8 & 38.9 & 0.7 \\
\hline $55-64$ & 14.2 & 13.2 & 52.6 & 0.2 \\
\hline $65-74$ & 17.5 & 21.4 & 58.5 & 0.1 \\
\hline$>74$ & 17.2 & 16.8 & 58.9 & 0.0 \\
\hline \multicolumn{5}{|c|}{ Baseline Extrapolated Household Survey 2008 to 2011} \\
\hline All & 18.3 & 21.8 & 40.0 & 2.0 \\
\hline \multicolumn{5}{|l|}{ Income } \\
\hline$<20$ & 83.7 & 79.6 & 96.6 & 7.5 \\
\hline $20-40$ & 27.1 & 28.2 & 46.3 & 3.5 \\
\hline $40-60$ & 19.8 & 12.9 & 30.5 & 2.0 \\
\hline $60-80$ & 14.8 & 9.7 & 34.3 & 3.8 \\
\hline $80-90$ & 10.9 & 6.8 & 39.4 & 0.0 \\
\hline $90-100$ & 8.1 & 7.0 & 35.6 & 0.7 \\
\hline \multicolumn{5}{|c|}{ Age of household head } \\
\hline$<35$ & 26.7 & 29.1 & 36.0 & 8.5 \\
\hline $35-44$ & 19.7 & 22.3 & 32.5 & 5.2 \\
\hline $45-54$ & 16.8 & 18.5 & 36.0 & 1.1 \\
\hline $55-64$ & 15.7 & 21.9 & 38.9 & 0.1 \\
\hline $65-74$ & 18.6 & 22.6 & 55.8 & 0.5 \\
\hline$>74$ & 17.1 & 22.0 & 44.8 & 0.0 \\
\hline
\end{tabular}

Source: IMF Staff Calculations based on Banco de España data $1 /$ in percent of GDP in 2008 and 2011 respectively 
Households' financial positions deteriorated in 2011. An increase in unemployment and a decline in house price significantly increased the stress to households' income and lowered households' net worth, while a decline in interest rate helped to lower debt service. ${ }^{15}$ The proportion of vulnerable indebted households increased to 21.8 percent in 2011 , from 16.5 percent in 2008. The share of debt-at-risk accounted for 40 percent, or about 32 percent of GDP. The distribution of the debt burden was positively skewed where low-income households were largely affected. The sensitivity analysis of household balance sheets is then calibrated on both baseline 2008 and 2011.

\section{Sensitivity tests scenarios}

\section{Households are primarily affected by higher interest rates, particularly on}

mortgages. With variable rates, a rise in interest rate directly increases the debt repayment, thus making it more difficult to households to service their debt. The sensitivity analysis show that the shares of vulnerable households and debt-at-risk increases fairly sharply under rising interest rate scenarios (Table 5). With a 100 basis points increase in interest rate, these shares increase by about 3 percent and 9 percent above baseline respectively for 2008 figures. At the same time, the proportion of debt at risk not covered by assets is doubled to about 2.4 percent of total household loans. The shock tends to have stronger impact on lower income households (Figures 18 and 19). Simulations conducted by BdE (2011b) with increases in interest rates by a 100, 200 and 300 basis points show that the strongest impact would be felt among households with average incomes, with increases in the interest bill of $1.5,2.5$, and 3.5 percentage points of income. Despite a higher level of debt to income, households in the lowest income brackets are relatively less affected. This is due to the higher share of fixed interest rate borrowing (largely due to more prevalent consumer credit, more than two-third of which at fixed rates). ${ }^{16}$ The impact on households with debt service to income ratios over 40 percent would be moderate overall. ${ }^{17}$

\section{Income shocks appear to have a moderate impact on households' debt servicing} ability. With the current recession and labor market reform potentially increasing wage flexibility, this may imply some degree of wage moderation in order to maintain employment through labor hoarding, or to better align wages to competitors'. Consequently, labor income may fall. The sensitivity analysis calibrates the impact of a drop in household income across all households by certain percentage points. With 2008 baseline figures, a decline in household income by 10 percent would increase the share of vulnerable households to

\footnotetext{
${ }^{15}$ Blanco and Gimeno (2012) also find that the increase in the unemployment rate was the main driver of the sharp rise in default ratios between 2007 and 2009 in Spain. It is often argued that in Spain, a deterioration in debt service ability has first and foremost a strong impact on consumption patterns rather than immediately on default ratios, presumably due to the full recourse nature of mortgages.

${ }^{16}$ Our simulation makes the assumption that all rates are variable. Though variable rates largely predominate some pockets of household debt have a larger share of fixed rates.

${ }^{17}$ Like us, the study has assumed the same rate of income growth across categories between 2009 and 2011, and this could introduce a bias in the results. It does make a distinction by type of household debt, whereas we treat all debt as mortgages with flexible rates.
} 
20.1 percent, from 16.5 percent in the baseline. The share of debt at risk in total household loans also increases to 50.4 percent, or about 41 percent of GDP. Nonetheless, to large extent, these loans are covered by wealth - the non-covered part changing only slightly to 1.2 percent of total loans to households. With 2011 baseline figures, these shares are somewhat higher, with the

\section{Rising unemployment does not seem to particularly affect households' debt} servicing ability, though the effects of unemployment might not be fully captured by the analysis. Spain has seen a rise in unemployment by about 10 percent since the global financial crisis. The unemployment may further increase following the ongoing crisis and the reform to improve labor market flexibility, particularly in the short-term (Bernal-Verdugo, Furceri, \& Guillaume, 2012). However, the impact of unemployment on households' financial situations appears modest, though the finding is in line with other studies (e.g., Riksbank (2009), OeNB (2010)). With a 5 percent increase in unemployment rate, the proportion of vulnerable households rises by less than 2 percent from baseline and the share of debt at risk increases by only 0.4 percent from baseline. One potential explanation is that the shock may be partially absorbed by the income of other household members who are still employed, that activity in the grey economy can compensate income loss for some households and that there are back and forth movements to and from unemployment, limiting long term unemployment (though long term unemployment is high in Spain and twice the Euro area average, its share in total unemployment is in line with the Euro area; Figure 20). Moreover, important caveats include (i) the unemployment shock is generated with equal probability for all employed persons, whereas some segments of labor market such as construction workers may have higher probability of becoming unemployed; and (ii) the test does not take into account the unemployment duration. ${ }^{18}$ A more comprehensive analysis and avenue for further research would introduce shocks simulating an increase in the number of households with all their members unemployed, and an increase in long term unemployment. With a severe recession, unemployment spells are likely to take longer duration and affect a wider spectrum of the population. Unemployment benefits may expire for long-term unemployed persons, especially in a context of several years of crisis and a double dip recession. This may cause second-round effects further exacerbating households' ability to service their debts.

\footnotetext{
${ }^{18}$ The probability of becoming unemployed can be estimated based on households' characteristics, where the unemployment is a function of an individual's socioeconomic background, demographic characteristics, and geographic location (e.g., World Bank (2010) and OeNB (2010)).
} 
Table 5. Spain: Sensitivity Analysis of Indebted Households1/

(In percent, otherwise indicated)

\begin{tabular}{|c|c|c|c|c|}
\hline & $\begin{array}{l}\text { Ratio of Debt } \\
\text { Payment to } \\
\text { Household Income }\end{array}$ & $\begin{array}{l}\text { Share of } \\
\text { Distressed } \\
\text { Household }\end{array}$ & $\begin{array}{l}\text { Share of } \\
\text { Debt at } \\
\text { Risk }\end{array}$ & $\begin{array}{l}\text { Debt at Risk not } \\
\text { Covered by } \\
\text { Household Assets (in } \\
\text { percent of total } \\
\text { household loans) }\end{array}$ \\
\hline \multicolumn{5}{|c|}{ Baseline based on Household Survey 2008} \\
\hline Baseline & 18.1 & 16.5 & 45.9 & 1.1 \\
\hline \multicolumn{5}{|l|}{ Interest rate shock: } \\
\hline 100 bps increase in interest rate & 19.5 & 19.6 & 54.6 & 2.4 \\
\hline 200 bps increase in interest rate & 20.6 & 22.1 & 58.0 & 2.5 \\
\hline 300 bps increase in interest rate & 22.0 & 27.0 & 61.8 & 2.5 \\
\hline \multicolumn{5}{|l|}{ Income shock: } \\
\hline 5 percent decline in household income & 19.1 & 18.4 & 48.1 & 1.1 \\
\hline 10 percent decline in household income & 20.2 & 20.1 & 50.4 & 1.2 \\
\hline 20 percent decline in household income & 22.7 & 27.6 & 57.5 & 1.4 \\
\hline \multicolumn{5}{|l|}{ Unemployment shock: } \\
\hline 1 percent increase in unemployment rate & 18.2 & 17.6 & 45.9 & 1.1 \\
\hline 5 percent increase in unemployment rate & 18.3 & 18.3 & 46.3 & 1.1 \\
\hline rate & 18.7 & 18.4 & 47.1 & 1.2 \\
\hline \multicolumn{5}{|l|}{ House price shock: } \\
\hline 10 percent decline in house price & n.a. & n.a. & n.a. & 1.5 \\
\hline 20 percent decline in house price & n.a. & n.a. & n.a. & 1.8 \\
\hline 30 percent decline in house price & n.a. & n.a. & n.a. & 2.3 \\
\hline \multicolumn{5}{|l|}{ Combined shock } \\
\hline \multicolumn{5}{|l|}{$\begin{array}{l}10 \text { percent decline in household income, } \\
200 \text { bps increase in interest rate, } 20 \\
\text { percent decline in house prices and } 5 \\
\text { percent increase in unemployment rate }\end{array}$} \\
\hline \multicolumn{5}{|c|}{ Baseline extrapolated Household Survey 2008 to 2011} \\
\hline Baseline & 18.3 & 21.8 & 40.0 & 2.0 \\
\hline \multicolumn{5}{|l|}{ Interest rate shock: } \\
\hline 100 bps increase in interest rate & 23.1 & 28.8 & 58.9 & 3.7 \\
\hline 200 bps increase in interest rate & 24.7 & 31.6 & 62.7 & 3.8 \\
\hline \multicolumn{5}{|l|}{ Income shock: } \\
\hline 5 percent decline in household income & 22.9 & 27.6 & 52.6 & 2.3 \\
\hline 10 percent decline in household income & 24.2 & 30.0 & 55.0 & 2.5 \\
\hline \multicolumn{5}{|l|}{ Unemployment shock: } \\
\hline 1 percent increase in unemployment rate & 22.0 & 26.0 & 50.8 & 2.3 \\
\hline 5 percent increase in unemployment rate & 22.1 & 26.5 & 51.6 & 2.3 \\
\hline rate & 22.3 & 27.2 & 54.6 & 2.4 \\
\hline \multicolumn{5}{|l|}{ House price shock: } \\
\hline 10 percent decline in house price & n.a. & n.a. & n.a. & 2.7 \\
\hline 20 percent decline in house price & n.a. & n.a. & n.a. & 3.1 \\
\hline 30 percent decline in house price & n.a. & n.a. & n.a. & 3.8 \\
\hline \multicolumn{5}{|l|}{ Combined shock } \\
\hline $\begin{array}{l}10 \text { percent decline in household income, } \\
200 \text { bps increase in interest rate, } 20 \\
\text { percent decline in house prices and } 5 \\
\text { percent increase in unemployment rate }\end{array}$ & 27.7 & 36.1 & 67.3 & 5.1 \\
\hline
\end{tabular}

Source: IMF Staff Calculations based on Banco de España data

$1 /$ in percent of GDP in 2008 and 2011 respectively 


\section{A further correction in the housing market may lead to additional losses from}

household. The estimated overvaluation of housing prices in Spain had been estimated at about 20-30 percent (IMF, 2011b). So far, nominal house prices have fallen by about 25 percent from the peak (depending on the index used), thus the remaining correction should continue to take place, especially as it is inventory driven and this is poorly captured by models of overvaluation. The test assumes changes in house prices affect the household's real estate wealth and net worth. Such changes would directly impact the household's capacity to repay with their assets, should households no longer be able to service their debt. ${ }^{19}$ With a 20 percent decline in house price, the debt at risk not covered by household assets would increase by about $0.7-0.8$ percent of total loans to households. At the same time, debt at risk not covered by household assets would rise to 1.5 percent and 2.5 percent of GDP, for 2008 and 2011 figures, respectively.

\section{Scenario analysis}

\section{A challenging economic outlook in 2012 and 2013 is expected to further}

deteriorate indebted households' financial positions. The share of vulnerable households and debt at risk would increase to 25.5 percent and 50.3 percent under the baseline scenario (Table 6). The proportion of debt at risk not covered by household assets would rise to 2.6 percent of loans to households or 2.1 percent of GDP. Adverse scenarios analyze the impact of a more severe recession on household's balance sheets. A sharp decline of output growth for two consecutive years under the IMF's adverse scenario could cause a third of the Spanish households to become vulnerable, with a share of debt at risk reaching two-third of loans to households. Consequently, the debt at risk not covered by household assets would reach a peak of about 5 percent of total households' loans and 4 percent of GDP.

\footnotetext{
${ }^{19}$ Changes in asset prices may also affect the amount saved in the repayment vehicle, thus affecting the household's debt service ability and the share of vulnerable households. However, the estimates above reflect only partial equilibrium, in which the test does not take into account the interactions between income, saving, or debt.
} 
Table 6. Spain: Scenario Analysis of Indebted Households6/ (In percent, otherwise indicated)

\begin{tabular}{lcccc}
\hline & $\begin{array}{c}\text { Ratio of Debt } \\
\text { Payment to } \\
\text { Household Income }\end{array}$ & $\begin{array}{c}\text { Share of } \\
\text { Distressed } \\
\text { Household }\end{array}$ & $\begin{array}{c}\text { Share of } \\
\text { Debt at } \\
\text { Risk }\end{array}$ & $\begin{array}{c}\text { Debt at Risk not Covered by } \\
\text { Household Assets (in percent of } \\
\text { total household loans) }\end{array}$ \\
\hline $\begin{array}{l}\text { Baseline 2011 } \\
\text { Baseline }\end{array}$ & 21.3 & 21.8 & 40.0 & 2.0 \\
& 21.4 & 25.5 & 50.3 & 2.6 \\
Adverse Scenario: BdE & 21.9 & 26.3 & 50.7 & 2.8 \\
Adverse Scenario: IMF & 24.2 & 29.8 & 59.7 & 4.9 \\
\hline \hline
\end{tabular}

Source: IMF Staff Calculations based on Banco de España data.

1/ in percent of 2011 GDP for baseline 2011 and in percent of 2012-13 GDP for baseline and adverse scenarios.

\section{CORPorate AND FinanCial SeCtor LinKages}

\section{A. Developments During and After the Crisis}

31. The increase in corporate sector indebtedness has been driven in large part by the housing boom. Though the initial level of corporate debt was already high in Spain (albeit below the euro area average in 1999), it now largely exceeds most EU countries, with the exception of Ireland (Figure 21). During the boom years of 2004-2008, construction explained 8 percent of private sector credit growth, real estate activities (largely real estate development) 22 percent, and the acquisition of real estate (mortgages) 33 percent. ${ }^{20}$ Real estate activities have contributed disproportionately to the increase in corporate credit, much more than construction itself, which seems less out of line (Figure 22). The outcome is that as a result of the boom, construction and real estate sector debt owed to Spanish banks represent a relatively high 10 percent and 30 percent of GDP respectively.

\section{The construction and real estate sectors are large, highly leveraged and rely}

more on bank financing than in other countries. Traditionally, construction and real estate are activities more leveraged than other sectors. In Spain, this stands out clearly for large companies listed on the stock market, though this also reflects the financial profile of large companies that have expanded abroad and in activities that range beyond their original specialization (Figure 23). More broadly, not only the sector is more leveraged than other sectors, but the Spanish construction sector is also more leveraged than its peers (Figure 24). The construction sector in Spain also tends to rely more on bank debt than in other countries (Figure 25). ${ }^{21}$ This would explain in part the high exposure of the Spanish banking system to these sectors.

\footnotetext{
${ }^{20}$ Hence, construction and real estate activities explain more than half of the increase in bank lending to the corporate sector during the boom years.

${ }^{21}$ In the BACH database some real estate developers are included in the construction sector.
} 
33. The construction and real estate sectors apart, leverage in the corporate sector is still slightly higher than in most euro area countries. ${ }^{22}$ This is true on average for Spain, while some sectors (like hotels and restaurants) appear more leveraged. This suggests that the relatively high level of corporate indebtedness prevalent in Spain will not necessarily go away only with the scaling down of construction and real estate activities. Excluding construction and real estate activities, corporate debt could be estimated as representing the equivalent of 143 percent of GDP, still higher than the euro area average. ${ }^{23}$ Some of this debt, especially for large firms is associated with international activities.

34. The adjustment of credit stocks is lagging. It is normal for the stock of mortgages to take a long time to adjust, given the maturity structure of the loan portfolio. Credit to construction has adjusted significantly, as it has done in the previous comparable recession episode in Spain (1993-1994) and due to its predominantly shorter maturity structure. But there has been relatively little adjustment in the large stock of loans to real estate activities (Figure 26). The stock net of provisions has adjusted significantly but it remains that the gross stock has declined modestly. Despite a lower average maturity, it has adjusted in line with the mortgage portfolio, and much less than in other countries (IMF, 2011b). Not all loans are directed to property development, but a part of loans to developers (in particular) is being renegotiated to help them cope with the deep downturn in the sector. There is strong anecdotal evidence in particular that large developers have been renegotiating regularly and refinancing some of their syndicated loans, albeit with difficulties (case of several large developers) and may signal delayed restructuring.

35. The BdE has rules in place to monitor corporate debt restructuring. For these exposures, and in particular large ones the analysis is conducted on an individual basis. Within BdE, a full-time supervisory team is in charge of analyzing these operations in order to conduct a common assessment of the creditors and therefore of all its operations, included refinanced ones, in the context of a company rating system. The analysis covers around 240 Spanish companies — on a consolidated basis - that represent around 28 percent of lending to nonfinancial companies. Once the common assessment has been agreed, the supervisory teams of each credit institutions may apply it taking into account the specific conditions of each loan (for example, the treatment of a debtor may be different in two banks because of different LTV). According to this system, most of the companies with restructured are rated as doubtful. The system also serves to given an internal rating to the largest groups (Figure 27).

\footnotetext{
${ }^{22}$ See IMF 2011 (b). Since the breakdown of corporate debt by sector other than debt owed to banks was not available, we assumed a share of non bank debt of 56 percent for construction and 29 percent for real estate activities (based on BACH data).

${ }^{23}$ Since the breakdown of corporate debt by sector other than debt owed to banks is not available, we assume a share of nonbank debt of 56 percent for construction and 29 percent for real estate activities (based on BACH data).
} 


\section{B. Contingent Claims Analysis of the Corporate Sector}

\section{Corporate failures could potentially have significant impacts on the economy in terms of employment, output loss, and distress in the banking sector. This section applies the Contingent Claims Analysis (CCA) to detect corporate vulnerabilities and the underlying risks (Box 3). Given the firm's leverage and the uncertainty on its asset values, the CCA calibrates the risk of defaults and the potential losses in the case of corporate defaults.}

\section{Box 3. Contingent Claims Analysis of the Spanish Corporate Sector}

The Contingent Claims Analysis (CCA) provides a methodology to combine balance sheet information with modern finance theory to construct marked-to-market balance sheets that better reflect underlying risk (Gray and Malone (2008)). This is particularly of interest as most Spanish NFCs' borrowings are through credit institutions. Identifying the corporate vulnerabilities as well as the credit risk from corporate defaults can give a clearer picture of the interrelated balance sheets across the two sectors.

The total market value of assets of a firm is equal to firm's equity plus debt, $A=D+E$. Equity can be modeled and calculated as an implicit call option on the assets, where the equity holder would receive the maximum of either assets minus the distress barrier (DB), or nothing in the case of default, $E=\max [A-D B, 0]$. However, the value of debt is risky, as there is a chance of default on the debt. Risky debt is then defined as a claim on uncertain assets, so-called contingent claims. Debt holders are obliged to absorb losses in the case of default and receive either the default-free value or the senior claim on assets in the case of default. In other word, the value of risky debt is the default-free value of the debt minus the expected loss. Following the Black-Scholes-Merton, the value of expected loss or the guarantee against default is equivalent to the value of an implicit put option, $P(t)$ on firm assets with the strike price being the default barrier (e.g., Merton (1974)), thus $D=D B-\max [D B$ $A, 0]$.

$$
\text { Or equivalently, } \quad B(t)=E^{-r y}-F^{-2}(t)
$$

where $B$ the promised payment, $r$ the risk-free rate and $T$ - $t$ periods to maturity.

The CCA imputes the value and volatility of assets using the market value of equity from the stock price and volatility data and firms' balance sheet information to calculate risk indicators such as the probability of default, credit spreads, the distance to distress, as well as the expected losses given defaults. The analysis uses the data from Moody's KMV for 107 Spanish listed NFCs, accounting for only a portion of total assets of all NFCs ${ }^{1 /}$. The value of expected loss given defaulted is estimated as

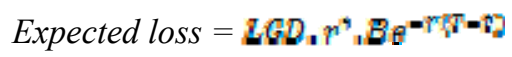

where $L G D$ is the loss given default or one minus the recovery rate, and $r^{*}$ is the risk-neutral default probability.

1/ Despite the fact that the CCA only captures the developments in listed companies, it is proved to be helpful in identifying corporate vulnerabilities and how bankruptcies can develop in the corporate sector (e.g., Gapen and others (2004), Riksbank (2009)).

\section{The risk of corporate sector defaults has reached historic highs, yet continues to} rise. Although not far-off that of peers, the median expected default frequency (EDF) for listed corporate in Spain increased to 0.8 percent in February 2012, from 0.4 percent at the peak of the global financial crisis or from only 0.1 percent pre-crisis (Figure 28). In particular, the EDF for 10 percent of firms, at ninetieth percentile, surges to 14 percent. The proportion of firms with a one-year-ahead default risk exceeding 1 percent also increases to 10.7 percent in February 2012, from 8.6 percent at the height of the previous crisis. The 
uncertainty related to the euro area debt crisis as well as funding strains affects share prices and increases stock volatility. The large deterioration of the EDF indicates expectations that the percentage of bankruptcies may continue to increase substantially over the coming year.

38. The default risk has been most acute in the construction and real estate sector. The median EDF of these sectors has risen sharply by about 2 percent since the beginning of 2011 and is 4 times as much as that of all nonfinancial corporations. The median EDF of other corporate also increases but at slower pace of around $0.1-0.4$ percent. The developments are in line with the actual corporate defaults (Table 7). The number of insolvencies in the real estate sector during the first three quarters of 2011 was five times that of pre-crisis, while taking the largest share among all nonfinancial corporations. The number of bankruptcies overall remains high and is likely trending up.

Table 7. Bankrupt Companies by Main Economic Activity (Number of companies)

\begin{tabular}{lrcccc}
\hline & Total & \multicolumn{3}{c}{ Of w hich: } \\
\cline { 3 - 6 } & & Construction and Real Estate & Industry and Energy & Trade & Services \\
\hline 2004 & 193 & 46 & 58 & 38 & 12 \\
2005 & 927 & 188 & 329 & 185 & 100 \\
2006 & 916 & 200 & 297 & 192 & 104 \\
2007 & 1033 & 286 & 324 & 204 & 101 \\
2008 & 2894 & 1194 & 664 & 444 & 274 \\
2009 & 5175 & 1868 & 1245 & 891 & 474 \\
2010 & 4875 & 1232 & 987 & 494 & 534 \\
2011 Q1:Q3 & 4314 & 1489 & 806 & 733 & 451 \\
\hline \hline Source: $\mathbb{I N E}$ & & & &
\end{tabular}

39. The expected losses from corporate defaults may rise further. As of February 2012, the estimate of potential losses from the listed Spanish corporate account for about 0.7 percent of GDP (Figure 29). The corporate potential losses are the largest in the construction and real estate sector, - two-third of the total estimated. It is important to note that this estimate is based on small samples of the Spanish corporations. Taking into account all listed and nonlisted corporations, the potential losses from nonfinancial corporate defaults could be significantly higher.

\section{Sensitivity Analysis of the Corporate Sector}

40. This section examines the credit risk arising from corporate sector borrowing and firms' debt servicing ability. The analysis of corporate vulnerability is based on the sensitivity analysis of nonfinancial corporations' financial positions with respect to different types of shocks, including interest rate and profitability shocks (Box 4). The analysis aims to identify the most vulnerable firms that are under higher financial pressure to service their debt. Should this pressure materialize in corporate defaults, thiscould impair further the balance sheets of credit institutions, given the size of bank financing to the corporate sector in Spain. 


\section{Baseline}

\section{The financial position of Spanish nonfinancial corporations remains weak}

(Table 8). The Spanish corporate sector is on average highly leveraged. The sample is biased towards large companies, and the data is unconsolidated, when intra group debt is significant (the BdE estimates its share of intra-group debt at 30 percent. With these caveats in mind at the aggregate level, the interest coverage ratio appears comfortable at 3.4 percent. ${ }^{24}$ At the micro level, however, the share of financially distressed firms was significant at 23.4 percent, while the exposure at risk was nearly half of total loans to corporate sector or about 38 percent of GDP. These shares decreased slightly from the height of the crisis in 2009, following the (temporary) economic recovery and the low interest rate environment. Similar work at the BdE (2011c) but looking at the percentage of companies whose financial costs exceed the profits generated by ordinary activity (gross operating surplus plus financial revenue) show that industry, wholesale and retail trade, and accommodation services were quite affected with levels of stress similar to the previous 1992-1993 recession, but that large companies weathered this episode in a better position.

Table 8. Share of Financially Distressed Firms and Debt at Risk in 2010 (In percent, otherwise indicated)

\begin{tabular}{lcccc}
\hline & $\begin{array}{c}\text { Interest Coverage } \\
\text { Ratio 1/ }\end{array}$ & $\begin{array}{c}\text { Share of Financially Distressed } \\
\text { Firms in Each Group 2/ }\end{array}$ & $\begin{array}{c}\text { Share of Debt at } \\
\text { Risk in Each Group }\end{array}$ & $\begin{array}{c}\text { Number of Firms } \\
\text { in the Sample }\end{array}$ \\
\hline All & 3.4 & 23.4 & 45.4 & 7,041 \\
Industry: & & & & \\
$\quad$ Agriculture & 1.9 & 26.8 & 38.4 & 138 \\
Manufacturing & 5.4 & 19.2 & 22.8 & 1,719 \\
Utilities & 4.2 & 9.1 & 24.8 & 252 \\
Construction \&Real estate & 1.3 & 37.1 & 50.8 & 1,317 \\
Wholesale \&retail & 8.0 & 18.6 & 13.3 & 1,520 \\
Transportation & 5.4 & 12.7 & 3.9 & 331 \\
Other services & 2.2 & 25.2 & 77.7 & 1,764 \\
Size: 3/ & & & 25.1 & 3,430 \\
Small & 5.8 & 25.5 & 29.7 & 2,174 \\
Medium & 6.1 & 20.5 & 46.2 & 1,437 \\
Large & 3.3 & 22.8 & & \\
\hline \hline
\end{tabular}

Source: IMF Staff estimates, based on BdE data

1/ Earnings before interest and taxes divided by interest payment.

2/ Financially distressed firm is characterized if the interest coverage ratio is below 1 .

3/ Firm size is classified by number of employees. Small (less than 50 employees), medium (50-250 employees), and large (over 250 employees).

\section{The construction and services sectors appear most vulnerable (Figure 30). By}

industry, corporate debt is concentrated in the services sector, while equally distributed among construction and real estate, manufacturing, and utility sectors. Not surprisingly, construction and real estate have the highest share of financially distressed firms. The debt at risk is the highest for the service sector, followed by construction and real estate. By firm size, large firms however take the largest share of this sample at about 95 percent of loans to corporate sector, and the rest is for SMEs loans of only 5 percent of total loans or 4.3 percent

${ }^{24}$ For corporate, the Euribor three months is the dominant reference rate. 
of GDP. The share of financially distressed firms among SMEs and large firms is roughly comparable, though the sample used is mainly composed of large firms. However, the debt at risk issubstantial for large firms, given its share of the sample.

\section{Box 4. Sensitivity Analysis of Corporate Indebtedness}

The sensitivity analysis of firms' balance sheets aims to quantify the impact of macroeconomic shocks on their financial positions and debt servicing ability. The sensitivity analysis of the Spanish nonfinancial corporation considers two important shocks, on interest rate and profitability. The analysis assesses the share of vulnerable companies as well as thedebt at risk. The analysis is based on the firm-level data from the BdE's Central de Balances as of 2010. The data includes a sample of more than 8,000 Spanish NFCs of all size and industry ${ }^{1 /}$, representing more than 50 percent of total assets of all Spanish NFCs or about 35 percent of GDP.

The analysis uses the interest coverage ratio (ICR) to measure the firm's vulnerability (IMF, 2011a). A company is considered more vulnerable and that its debt is at risk, when its earnings before interest and taxes are less than interest payment due or the ICR is less than one. It should be noted that our analysis does not take into account the financial income - in some cases substantial - received by companies. The debt-at-risk, is the proportion of total debt (bank loans included) held by the firms most vulnerable and potentially in more difficultyto service their debt .

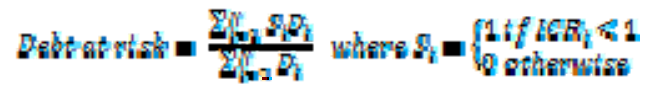

The sensitivity analysis would identify the changes in the proportion of these most vulnerable firms given the macroeconomic shocks. The shocks include the interest rate shock reflecting an increase in interest rate of 100, 200 and 300 basis points, (ii) the profit shock with a decline in profit before interest and tax by 10, 20 and 30 percent, and (iii) the scenario analysis in line with the assumptions of the banking sector's scenario analysis.

Table 9. Assumptions for Scenario Analysis

(In percent, otherwise indicated)

\begin{tabular}{|c|c|c|c|c|c|c|c|}
\hline & \multirow[b]{2}{*}{2011} & \multicolumn{2}{|c|}{ Baseline } & \multicolumn{2}{|c|}{ Adverse Scenario-BdE } & \multicolumn{2}{|c|}{ Adverse Scenario-IMF } \\
\hline & & 2012 & $\overline{2013}$ & 2012 & $\overline{2013}$ & 2012 & 2013 \\
\hline Real GDP & 0.7 & -1.7 & -0.3 & -2.5 & -0.7 & -4.1 & -1.7 \\
\hline Harmonized Index of Consumer Prices & 3.1 & 1.8 & 1.6 & 1.6 & 1.2 & 1.1 & 0.2 \\
\hline Gross Operating Surplus 1/ & -1.0 & -6.9 & -3.4 & -8.8 & -4.4 & -12.7 & -6.9 \\
\hline Euribor, 12 months & 2.0 & 1.6 & 1.5 & 1.6 & 1.5 & 2.6 & 2.5 \\
\hline
\end{tabular}

Source: BdE, IMF Staff Calculations.

$1 /$ The change in gross operating surplus is based on its estimated elasticity to real GDP.

1/ Firm size is classified by is classified by number of employees: small (less than 50 employees), medium ( $50-250$ employees). Firm industry includes construction and real estate, manufacturing, trade, utilities, transportation, agriculture, and services.

\section{Sensitivity tests scenario}

\section{The Spanish corporate sector is prone to both interest rate and profitability} shock, though less vulnerable to the latter (Table 10). The strong effect of interest rates reflects the leverage of Spanish firms, and also the impact of a variable rate structure that is assumed through the analysis. A one percent increase in interest rate would lower the interest coverage ratio by 0.7 percent, and the shares of financially distressed firms and debt at risk would increase by 3 percentage points and 4 percentage points respectively. Moreover, a profitability shock would add further financial strains. A 10 percent decline in firms' 
profitability would reduce the interest coverage ratio by 0.4 percent and the share of financially distressed firms would increase by about 1 percentage point.

Table 10. Sensitivity Analysis on the Spanish Nonfinancial Corporate Sector (In percent, otherwise indicated)

\begin{tabular}{lccc}
\hline & $\begin{array}{c}\text { Interest Coverage } \\
\text { Ratio 1/ }\end{array}$ & $\begin{array}{c}\text { Share of Financially } \\
\text { Distressed Firms 2/ }\end{array}$ & $\begin{array}{c}\text { Share of Debt at } \\
\text { Risk }\end{array}$ \\
\hline $\begin{array}{l}\text { Baseline } \\
\text { Interest rate shock: }\end{array}$ & 3.4 & 23.4 & 45.4 \\
100 bps increase in interest rate & 2.7 & 26.3 & 49.7 \\
200 bps increase in interest rate & 2.3 & 29.8 & 56.8 \\
Profit shock: & & & 45.7 \\
10 percent decline in profit & 3.0 & 24.1 & 46.3 \\
20 percent decline in profit & 2.6 & 25.1 & 51.8 \\
30 percent decline in profit & 2.2 & 26.3 & 61.1 \\
Combined shock: & & & \\
200 bps increase in interest rate & 1.5 & 36.4 & \\
and 30 percent decline in profit & & \\
\hline \hline
\end{tabular}

\section{The poorer financial position within the construction and real estate sector} would be further deteriorated by macroeconomic shocks (Figure 31). The interest rate and profitability shock has the largest impact to the construction sector and other nontradable sectors. The share of financially distressed firms in this sector would reach 51 percent with severe interest rate shock and the debt at risk would mount to two-third of the total debt of the sector; similar results are also evident for the profitability shock. As the actual bankruptcies of the sector already hits record high from housing bust, rapid economic downturn would increase financial strains and more defaults could be expected.

45. Smaller firms appear to be more vulnerable to macroeconomic shocks. To a large extent, smaller firms are highly dependent on local markets and their sources of income are less diversified. The shocks to the Spanish economy would affect these firms largely and more directly. On the other hand, large firms - especially exporting firms - may have relatively more diversified markets that could partly absorb the shocks and appear to be more resilient to shocks. The sensitivity analysis shows severe interest rate and profitability shocks would increase the debt at risk by 15 percentage points and 5 percentage points for smaller firms, whereas the impact of shocks is somewhat lesser for large firms. Nonetheless, the defaults of large firms would cause more substantial loan losses, given their large fraction of loans to corporate sector in the sample. 


\section{Scenario analysis}

46. A deepening recession would exacerbate further the financial positions of the Spanish corporations. With the recession in 2012 and 2013 under the baseline scenario, profits are estimated to decline by about 10 percent over two years, while the interest rate is expected to be 50 basis points lower. The share of distressed firms would increase to 24.2 percent and the share of debt at risk would rise to 45.8 percent (Table 11). With a more severe macroeconomic shock under adverse scenarios, the share of distressed firms would increase further by about 1.4-4.5 percentage points and the share of debt at risk would be about half of total debt of nonfinancial corporations.

\section{Table 11. Spain: Scenario Analysis on the Spanish Nonfinancial Corporate} Sector

\begin{tabular}{lccc}
\multicolumn{4}{c}{ (In percent, otherwise indicated) } \\
\hline & $\begin{array}{c}\text { Interest Coverage } \\
\text { Ratio 1/ }\end{array}$ & $\begin{array}{c}\text { Share of Financially } \\
\text { Distressed Firms 2/ }\end{array}$ & $\begin{array}{c}\text { Share of Debt at } \\
\text { Risk }\end{array}$ \\
\hline Baseline & 3.4 & 23.4 & 45.4 \\
Baseline 2012-13 & 3.0 & 24.2 & 45.8 \\
Adverse scenario: BdE & 2.5 & 25.6 & 47.5 \\
Adverse scenario: IMF & 2.0 & 28.7 & 55.0 \\
\hline \hline
\end{tabular}

Source: IMF Staff estimates, based on BdE data

1/ Earnings before interest and taxes divided by interest payment.

2/ Financially distressed firm is characterized if the interest coverage ratio is below 1 .

\section{Conclusions and Policy Implications}

47. Overall, despite areas of strength and factors mitigating economic stress, household indebtedness remains a concern. Mitigating factors (lower interest rates in particular) had an important role in the downturn. But since 2008, the debt servicing ability among households has weakened. Given the bleak economic outlook, the debt servicing ability is expected to deteriorate further. The sensitivity analysis carried out for the Spanish households show that households are most vulnerable to rising interest rate and weaker economic activity. The impact of the ongoing recession is expected to be most severe for borrowers among the poor and the young, which have already been hit hard.

48. The Spanish corporate sector remains vulnerable and credit risk in the Spanish corporate sector is expected to increase further. The current recession would aggravate firms' financial positions and debt servicing ability. The sensitivity analysis shows that a number of vulnerable firms and the debt at risk increase significantly with macroeconomic shocks. More defaults would be expected among most vulnerable sectors, including construction and real estate. Firms are adjusting and restoring their balance sheets. The deleveraging process will continue, but take long time to complete. Financial stress and corporate vulnerability would remain elevated for some time. Our analysis does not take into 
account the capacity of banks to renew or maintain their exposures to some firms particularly dependent on refinancing and already vulnerable in the downturn. This could constitute an additional factor of vulnerability for some SMEs, and in some sectors in particular (prime of which is the real estate and construction sectors).

\section{To address these vulnerabilities, policy steps have been taken but need to be complemented by further initiatives in particular in the corporate sector:}

- $\quad$ Policies to mitigate household stress have been put in place but more needs to be done. Royal Decree Law 6/2012 was approved on March 9, 2012 and seeks to put in place a multi pronged approach to distress for low income households and avoid socially costly foreclosures. Institutions representing 95 percent of the mortgage market have applied to its code of good practice, but its impact should be well contained to the most desperate situations. The definition of the target population of households is restrictive and should limit the application of the measures to those most in need. However, it might not be sufficient to deal with the effects of a prolonged recession with high and persistent levels of unemployment, though the problem is not sufficiently large at this stage and absent further substantial macroeconomic shocks to warrant large scale restructuring programs as implemented in some countries like the United States, Hungary, or Iceland, when these programs need careful design in terms of incentives and costs (Appendix II) ${ }^{25}$.

- $\quad$ At the same time, the full recourse system has served the Spanish mortgage market well, and limiting it on a compulsory basis would have disruptive effects on the financial system. Transforming full recourse mortgages into non recourse ones would distort the price of risk (interest rate), since the higher risk of a non-recourse mortgage would not be reflected in the original agreed terms for the (full recourse) mortgage. Lender forbearance in such a context of full recourse is acceptable as long as it responds to temporary problems of otherwise solvent borrowers. It is common practice in periods of economic stress, especially when the lender can wait out loan difficulties for a few quarters, but it is all the more important to be known, assessed and properly monitored. This does not preclude the need for lenders to recognize their losses and provision early on. The authorities should consider a thematic study on lender forbearance and risks in the mortgage market. This could lead to develop more comprehensive and publicly available guidelines on lender forbearance (such as in the United Kingdom), and improve reporting requirements. ${ }^{26}$ Though this has limitations,

\footnotetext{
${ }^{25}$ See also IMF (2009). The paper notes that if unaddressed, household debt distress could be a drain on the economy and lead to social unrest. Well-designed and well executed government intervention may be more efficient than leaving debt restructuring to the marketplace and standard court-based resolution tools alone. It proposes a template for a government-supported household debt restructuring program designed to reverse nonperforming loans, which could be adapted to individual country circumstances.

${ }^{26}$ See for example the guidelines from the UK FSA: www.fsa.gov.uk/pubs/guidance/fg11_15.pdf.
} 
enhanced protection against economic distress, such as mortgage insurance, could also be further developed.

- $\quad$ The overall leverage in the corporate sector masks widely different types of situations which calls for different policy responses. Part of the sector-the real estate and construction sector-is highly leveraged and bank financed. With little prospects for a rapid recovery of the housing market, it calls for more ambitious responses, perhaps in line with the London approach of corporate restructuring to complement ongoing efforts undertaken from the bank side, perhaps taking the form of a diagnostic study. Avoiding a situation of "zombie lending" in the corporate (to real estate activities) and delayed adjustment as in Japan should be a priority. Other measures that would reduce exposure of banks to developers could also be warranted. Several countries (e.g., France) after several problems with large developers at the end of the 1990s, have managed to greatly reduce their banks' direct exposure to real estate and construction companies. For the other sectors which are less leveraged, and in particular some SMEs asymmetries of information need to be reduced, as well as liquidity stress. The payment mechanism for suppliers of subnational governments (3.5 percent of GDP) will have a positive impact on many companies. Efforts in this direction should be pursued, notably with the help of ICO which has already put in place specific financing arrangements for SMEs. But it is only when bank balance sheets are cleansed from impaired assets in distressed sectors, that lending can be reallocated to more innovative and productive sectors of the economy. 
Figure 1. Selected Countries: Household Debt
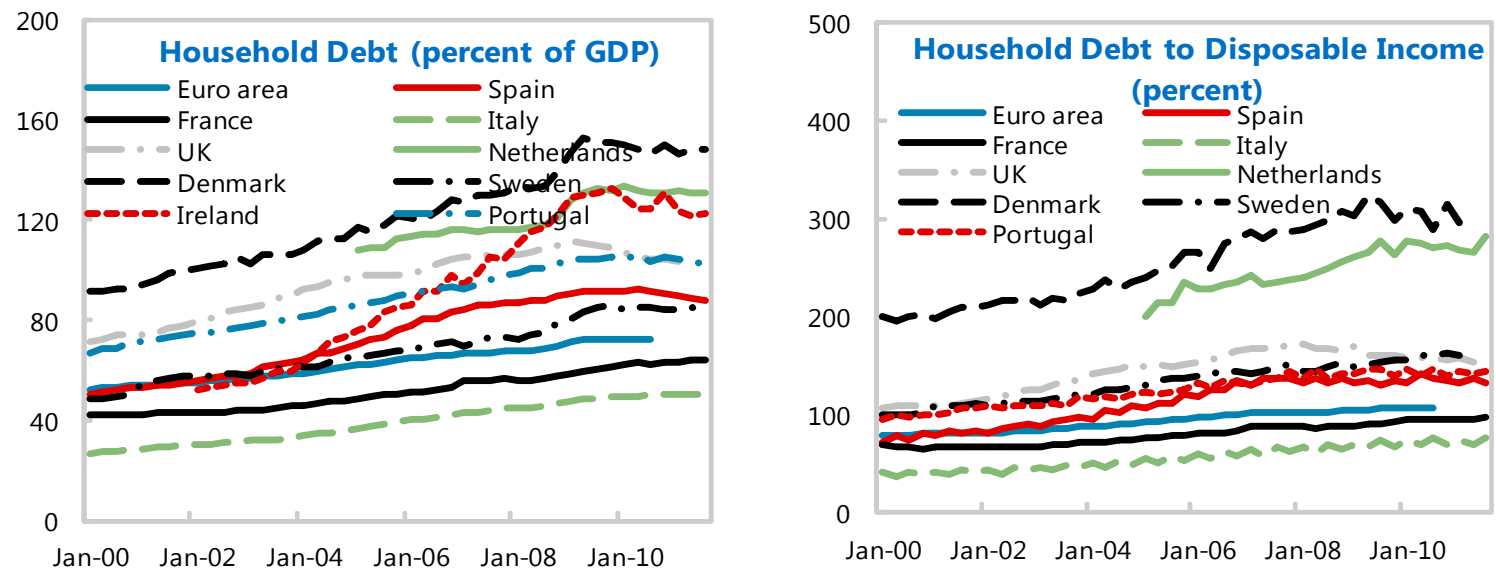

Sources: Eurostat; National Central Banks; and IMF staff estimates.

\section{Figure 2. Spain: Credit and Housing Prices}

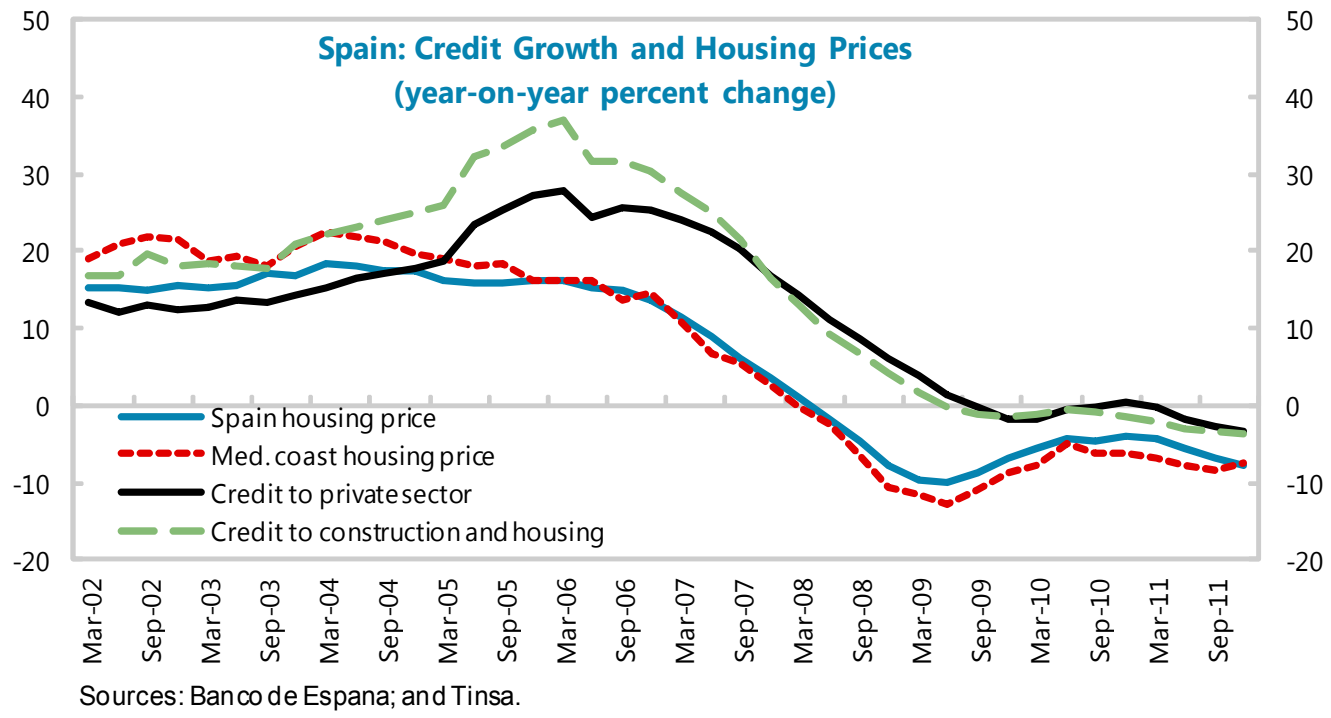




\section{Figure 3. Spain: Estimated Breakdown of Loans to Households by Income Category of the Borrower}

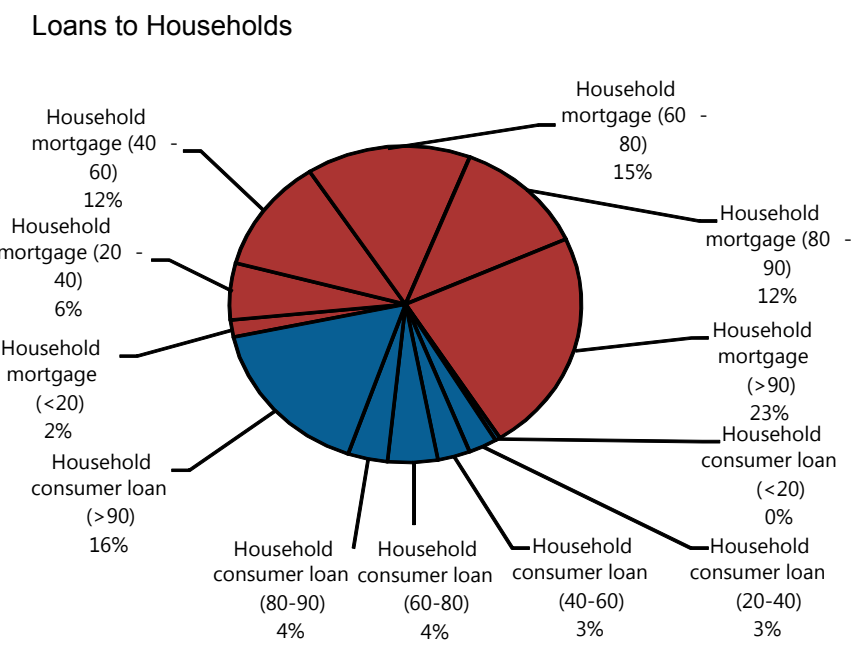

Sources: BdE and IMF Staff Estimates.

The breakdowns of loans to household were based on household borrowings from the 2008 household survey data. The number in parenthesis show the income ranking of households by income percentiles.

Figure 4. Spain: Household Borrowing Conditions
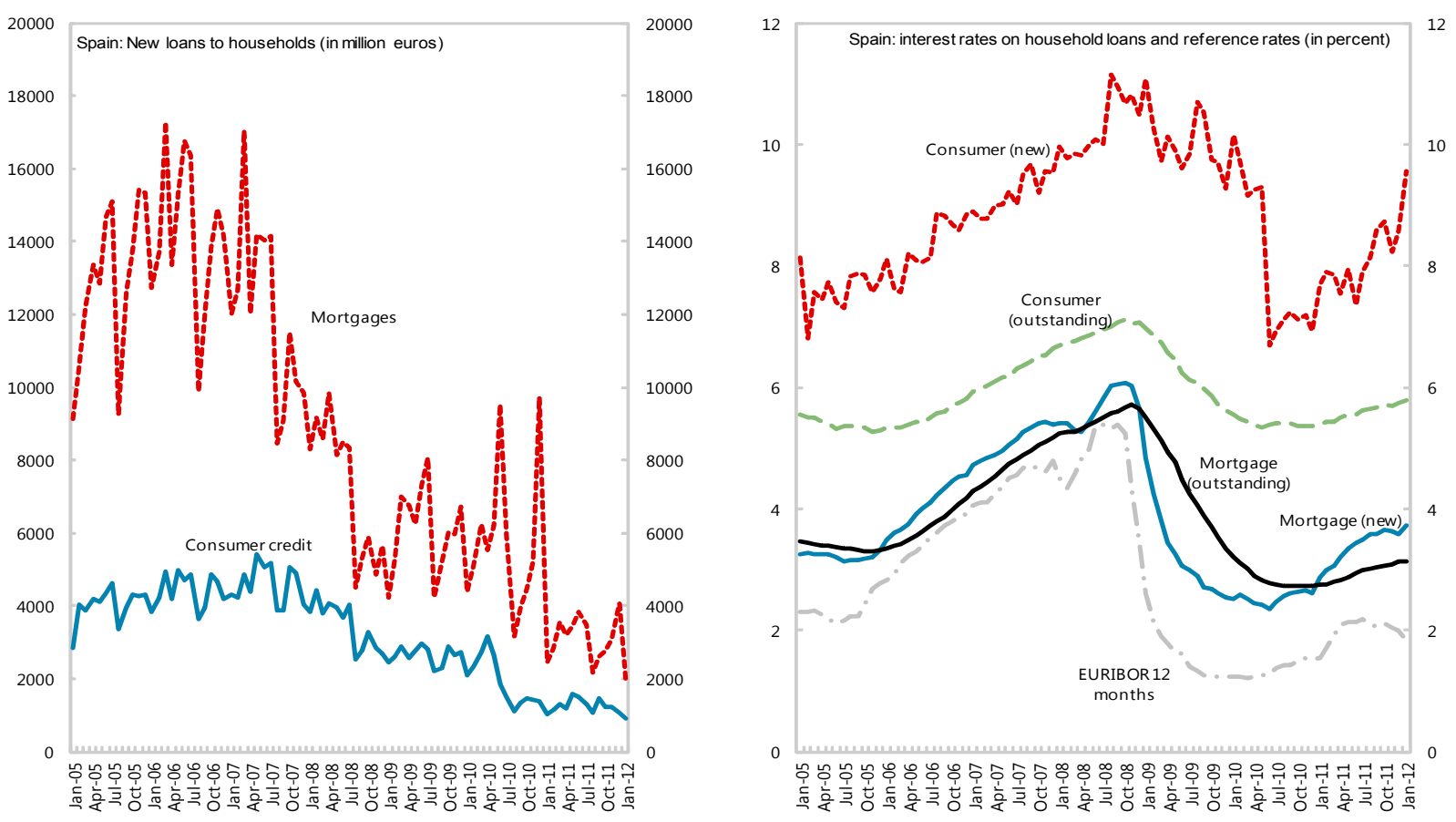

Source: Banco de España 
Figure 5. Spain: Household Wealth

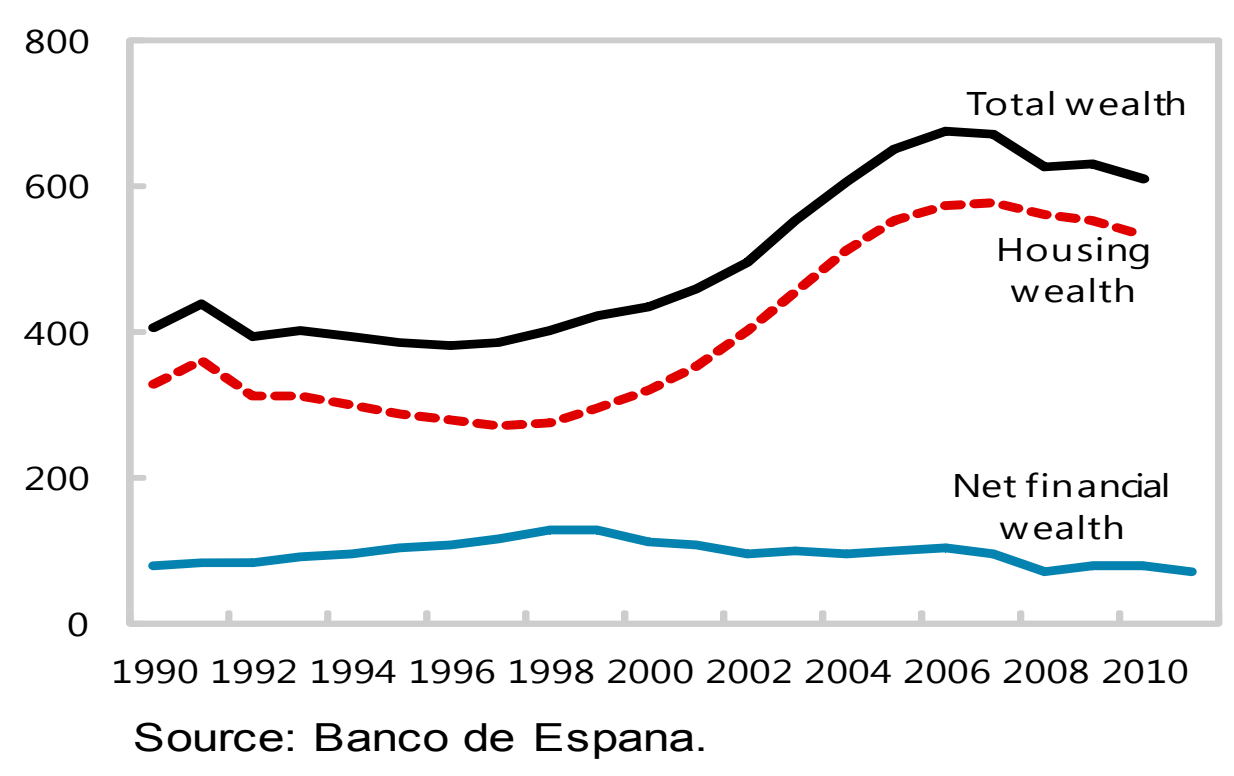


Figure 6. Selected Countries Household Debt

Households Owning Their Primary Residence

(By age category, in percent)

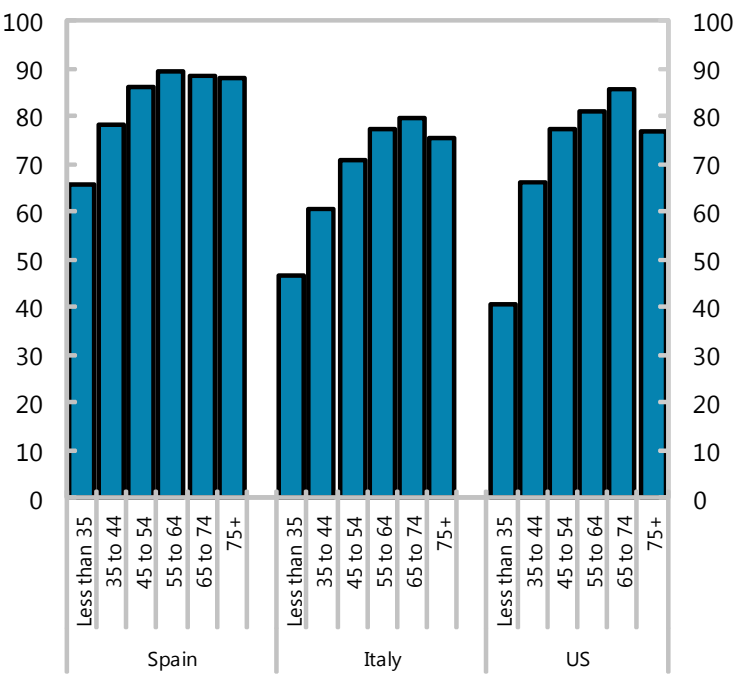

Selected Countries - Median Debt Service to Income (by age category, in percent)

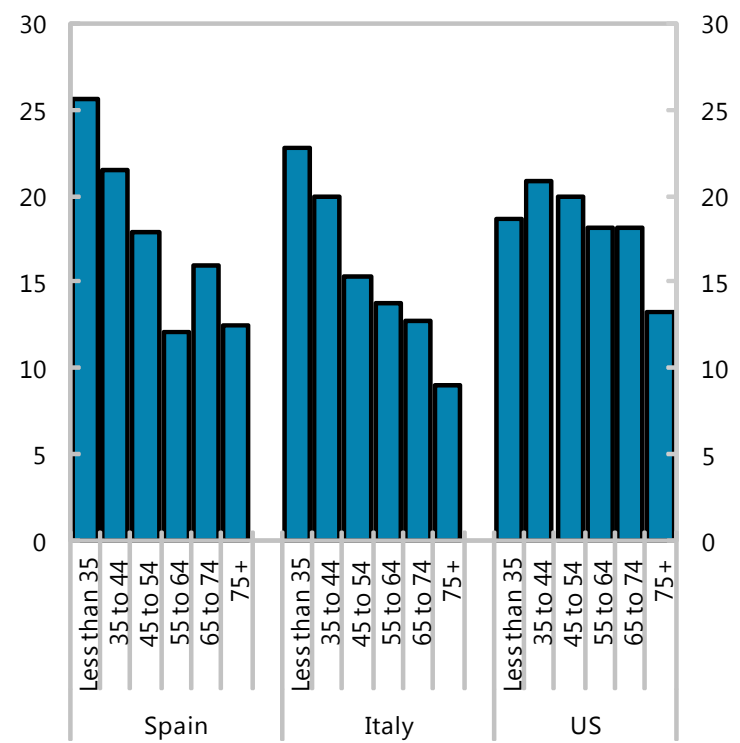

Source: Banco de Espana
Households with Real Estate Other Than Primary Residence

(By age category, in percent)

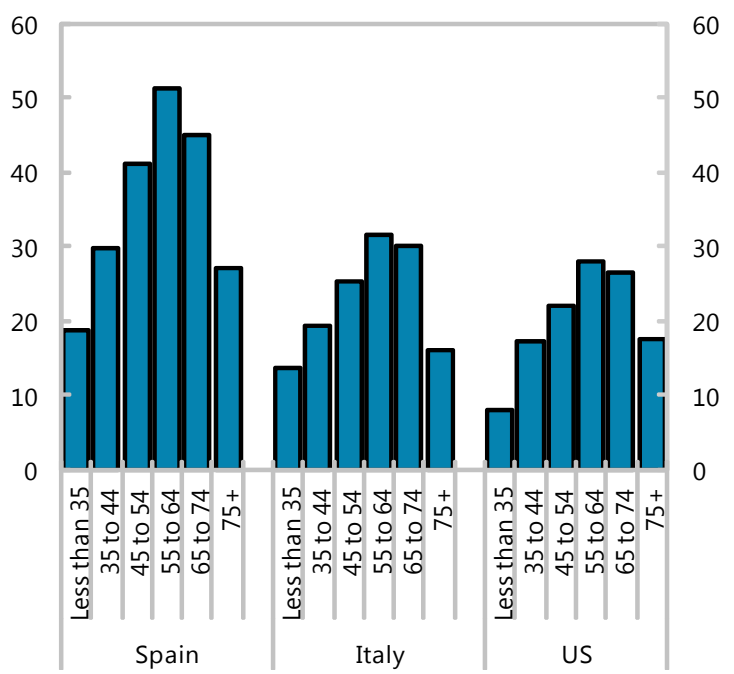

Selected Countries - Median Debt to Assets (By age of the head of household)

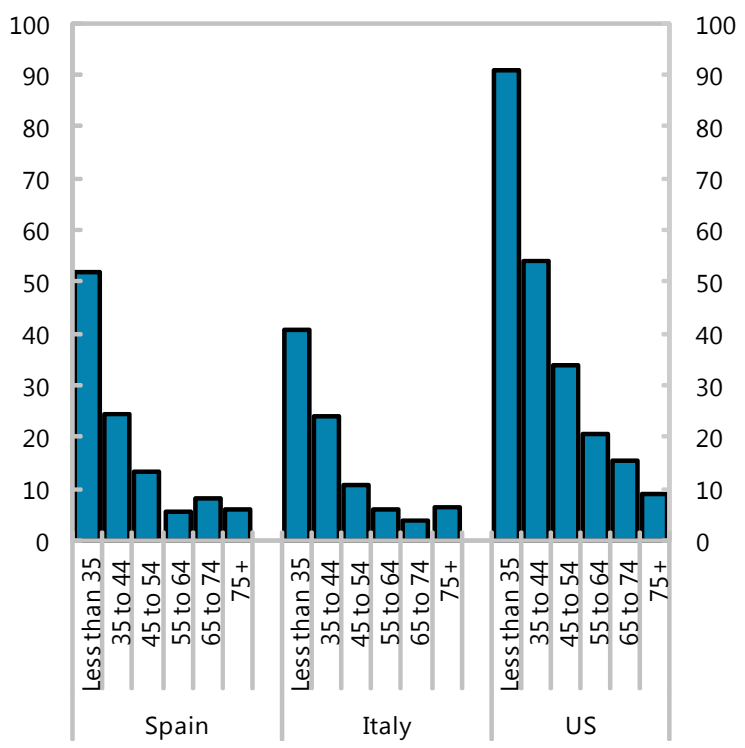


Figure 7. Selected Countries: Household Assets
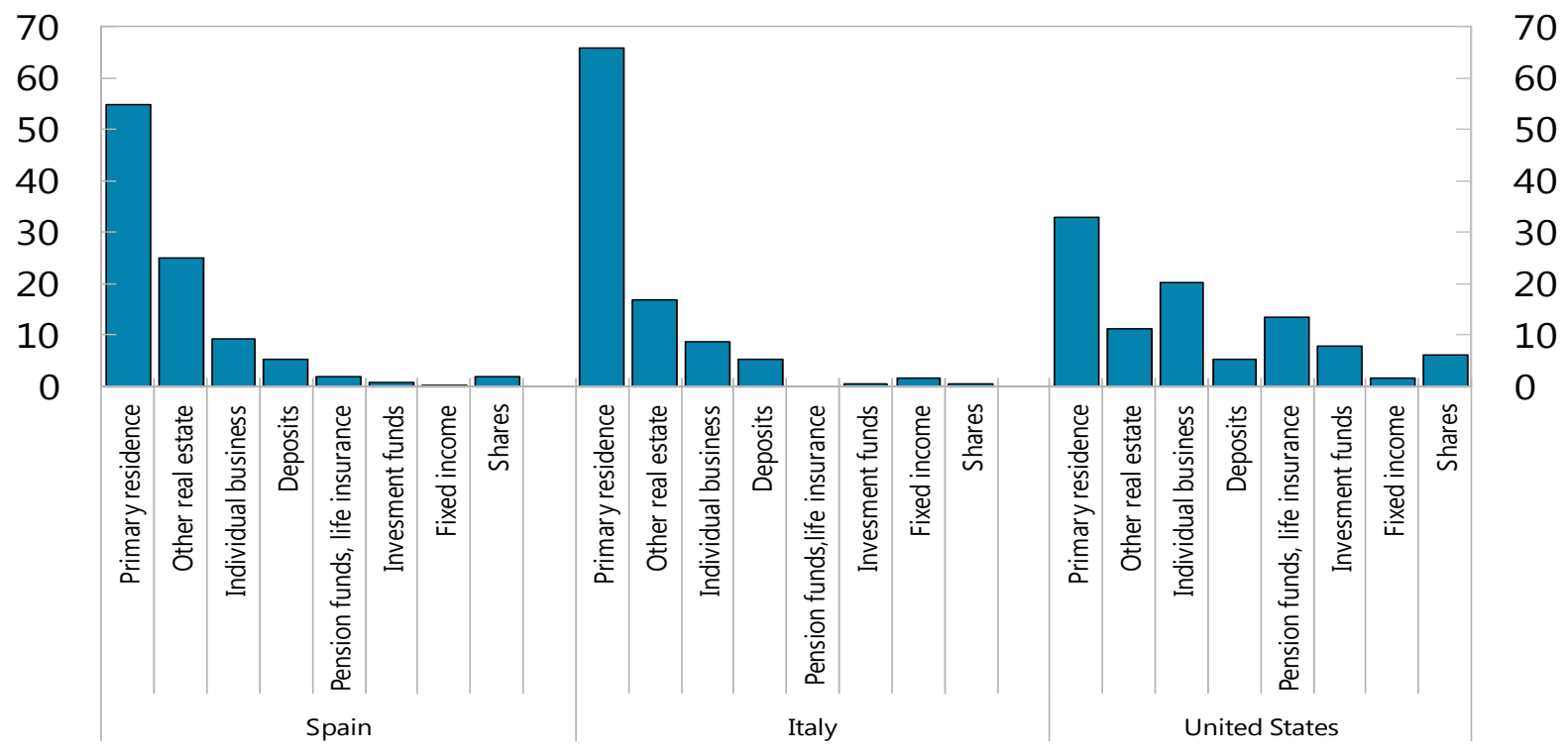

Sources: Banco de Espana

Figure 8. Selected Countries: Household Wealth
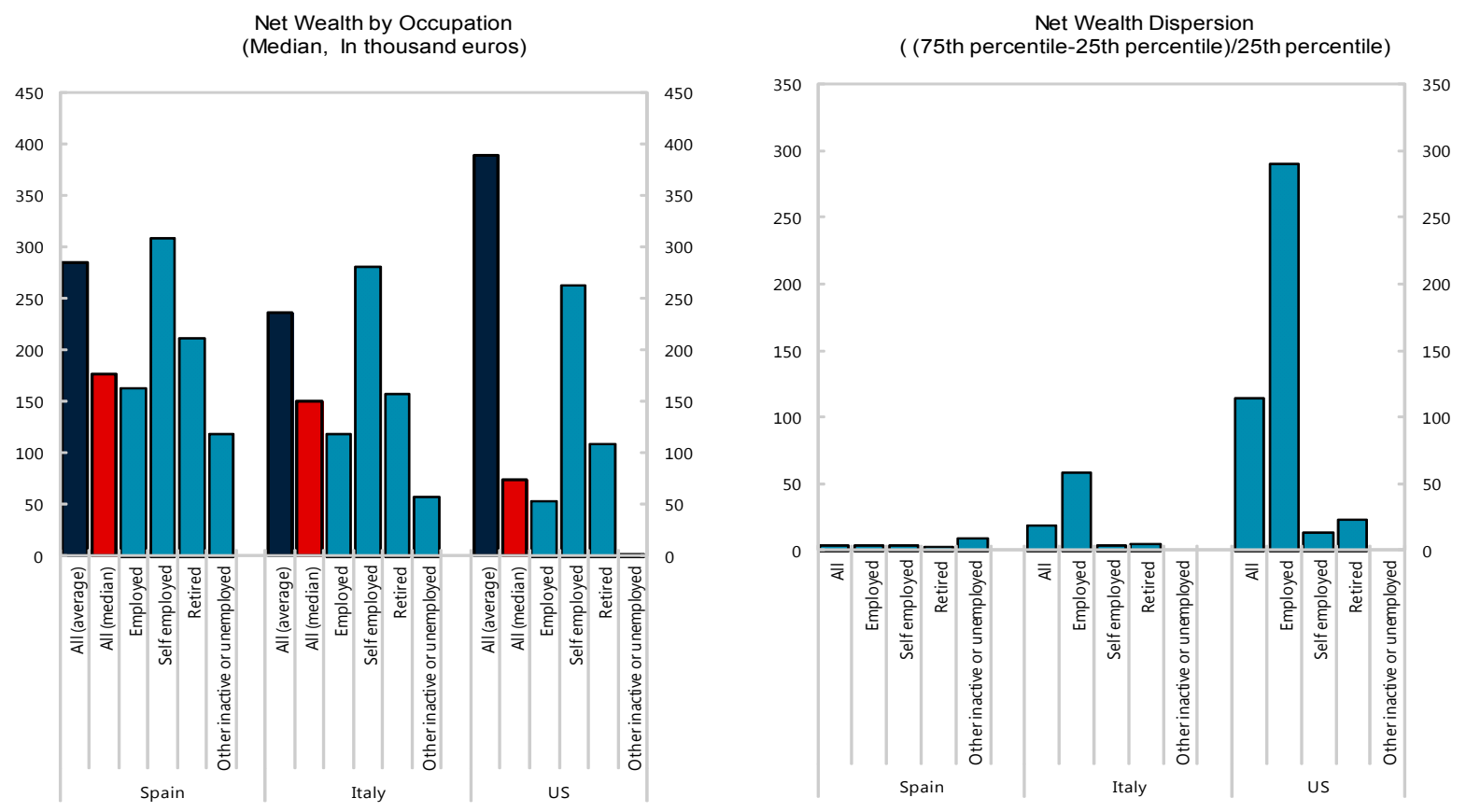

Source: Banco de Espana 
Figure 9. Selected Countries: Young Adults Living with Their Parents (Aged 18-34, in percent)

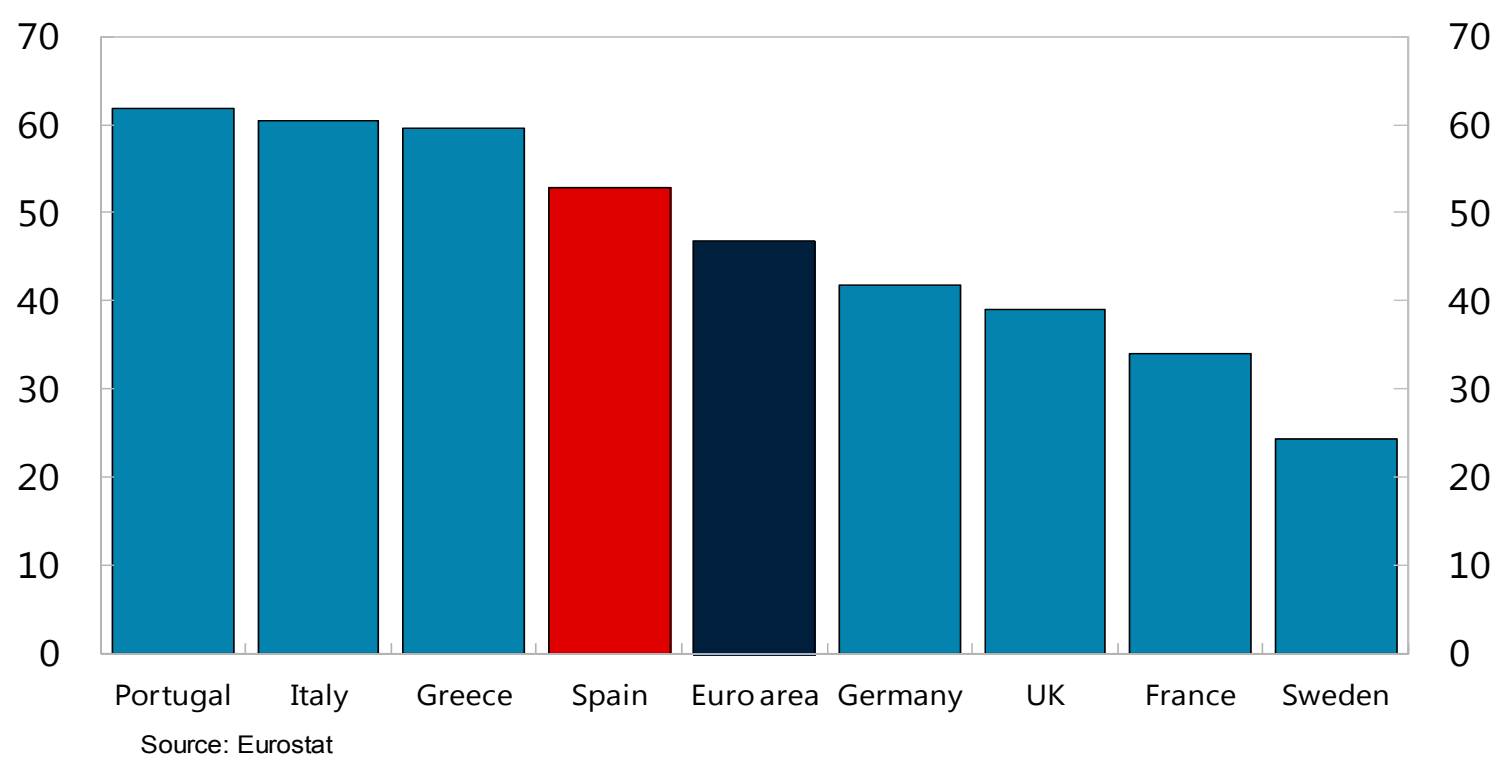

Figure 10. Evictions by Court Order (Per quarter)

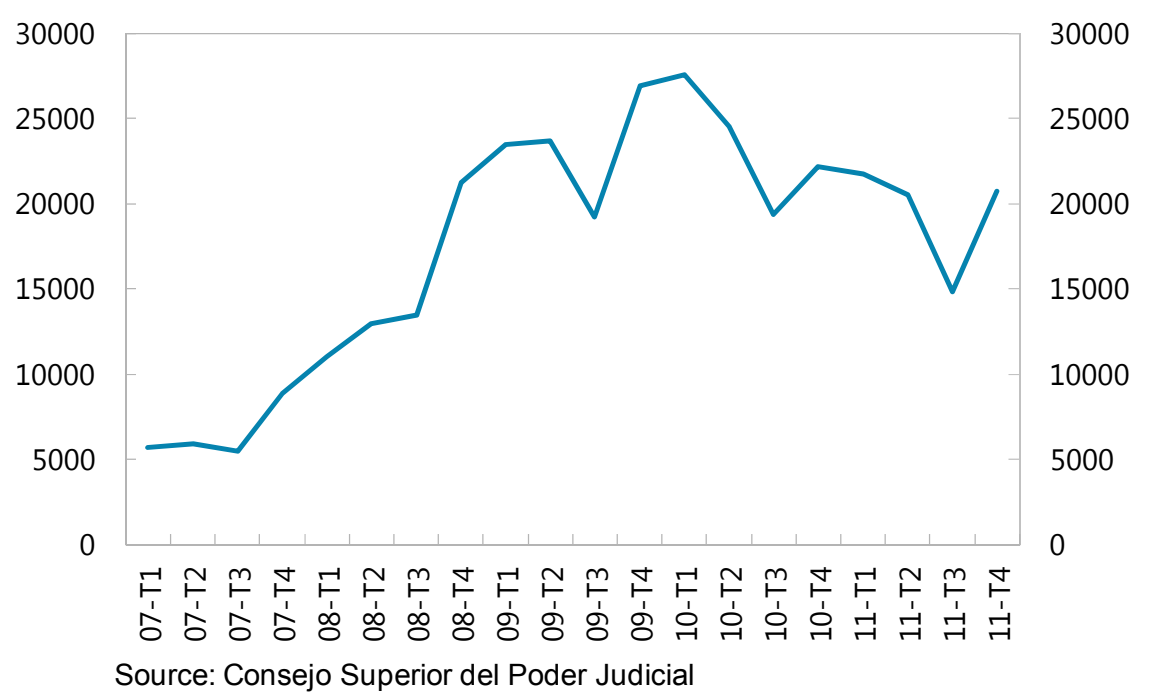


Figure 11. Spain: New Mortgage Loans and Mortgage Modifications
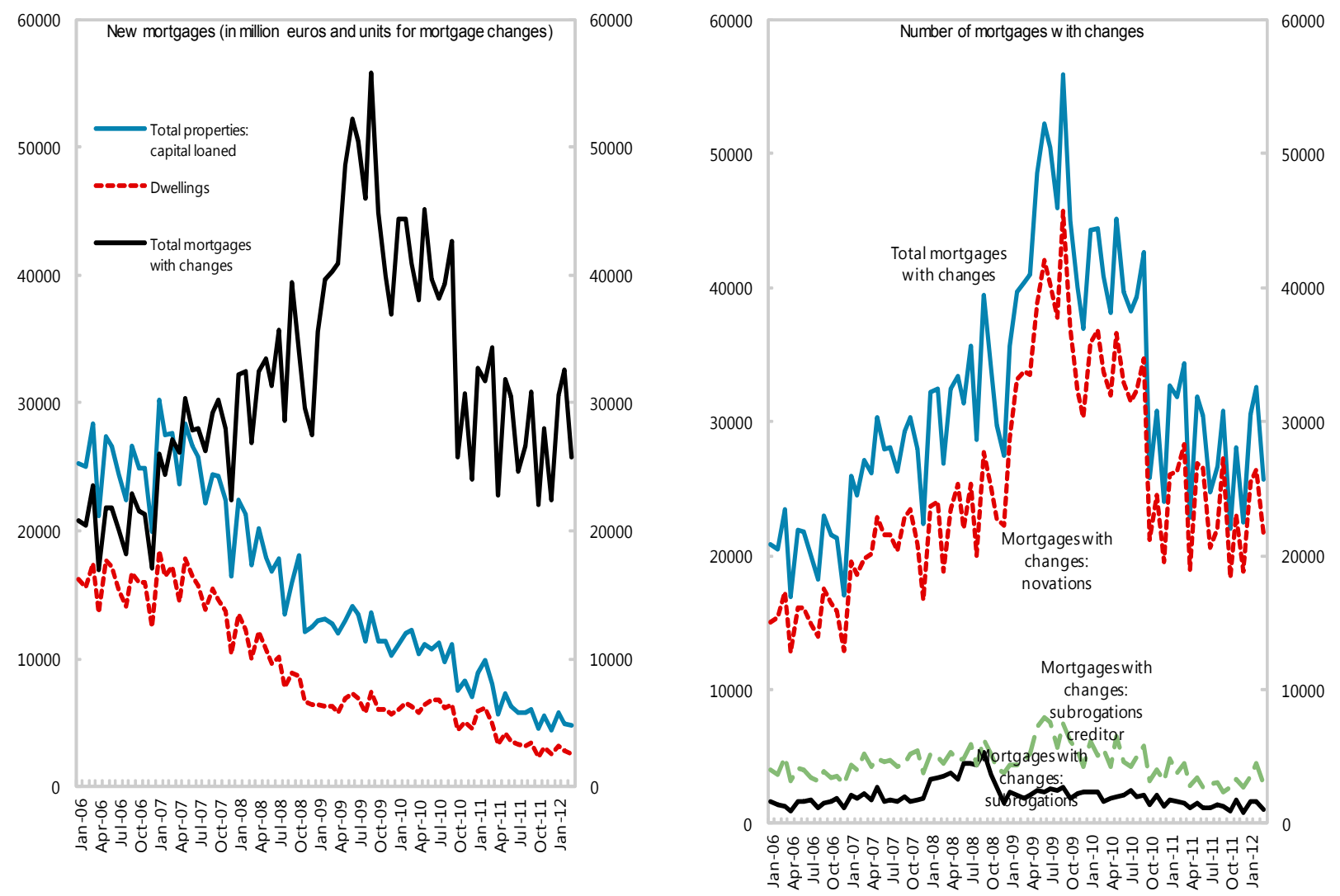

Source: INE 
Figure 12. Spain: Regional Dimensions of Mortgage Novations

Autonomous Communities - Mortgage Novations and Foreclosures

(Mortgage novations and foreclosures per 1000 inhabitants-2011)

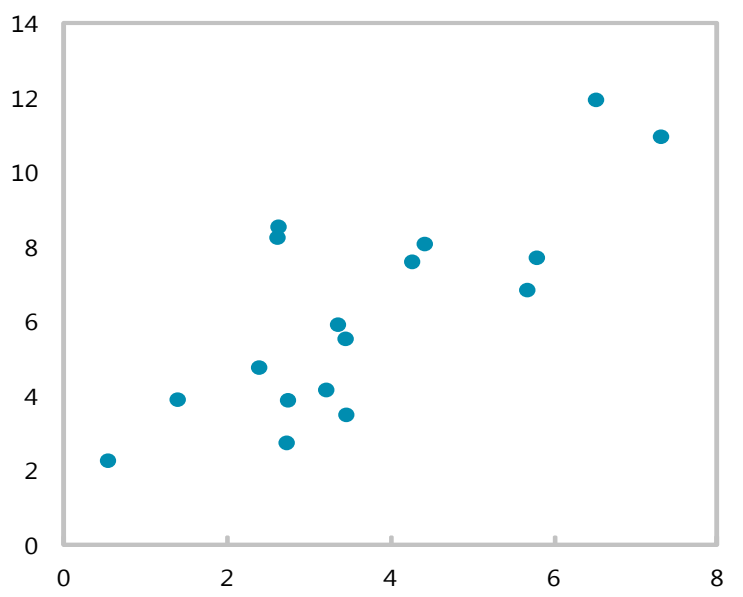

Provinces - Novations and Job Losses

(Novations per 1000 inhabitants, 2011, horizontal axis - Employment loss in percent2008-2011, vertical axis)

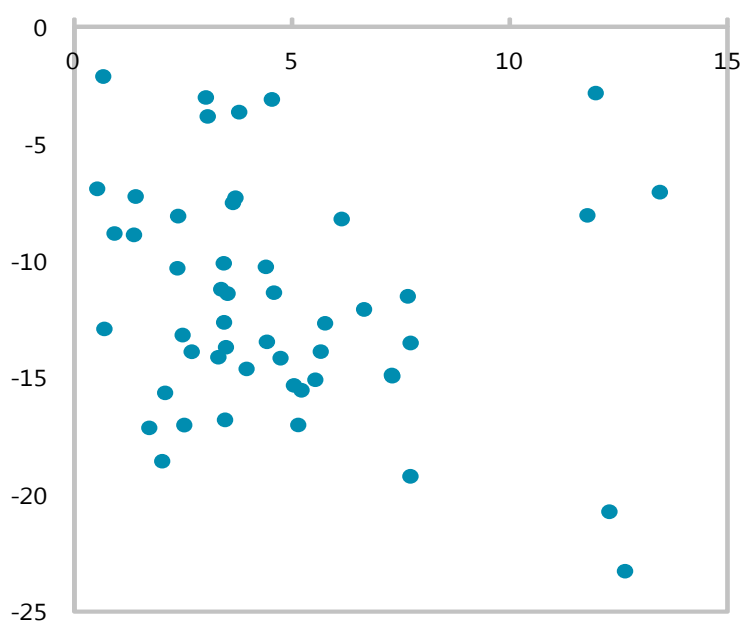

Provinces - Mortgage novations and Unemployment (2011; Novations per 1000 inhabitants, horizontal axis Unem ployment rate vertical axis )

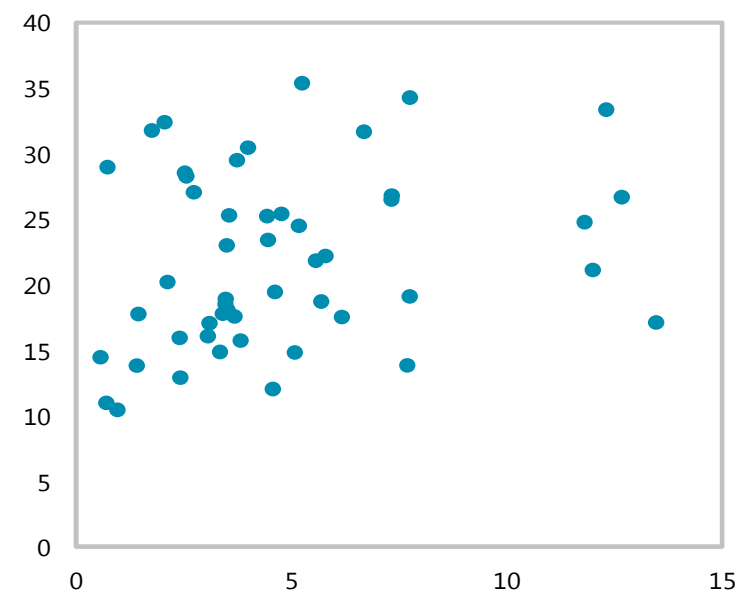

Provinces - Novations and Job Losses (Novations per capita in 2009, horizontal axis; Employment change 2008-2009, vertical axis )

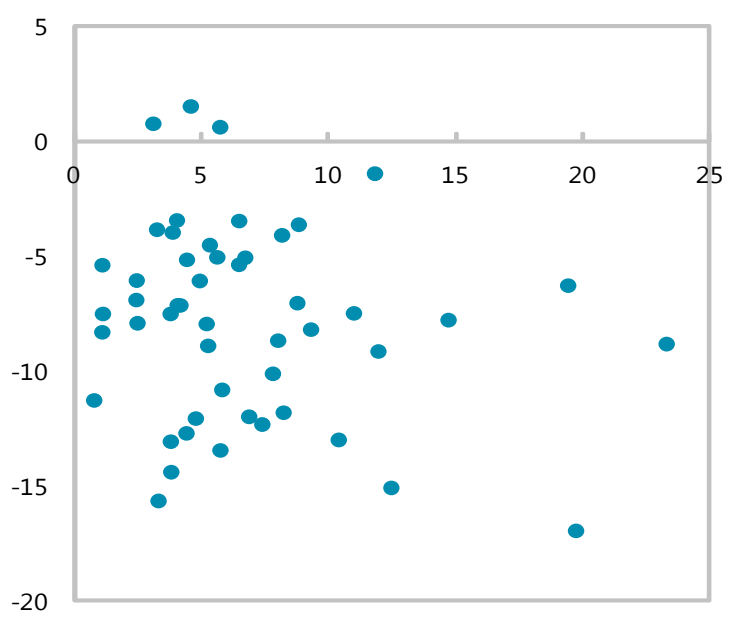

Sources: INE; and IMF Staff Estimates. 
Figure 13. Spain: New Mortgages/Property Sales

(In percent)

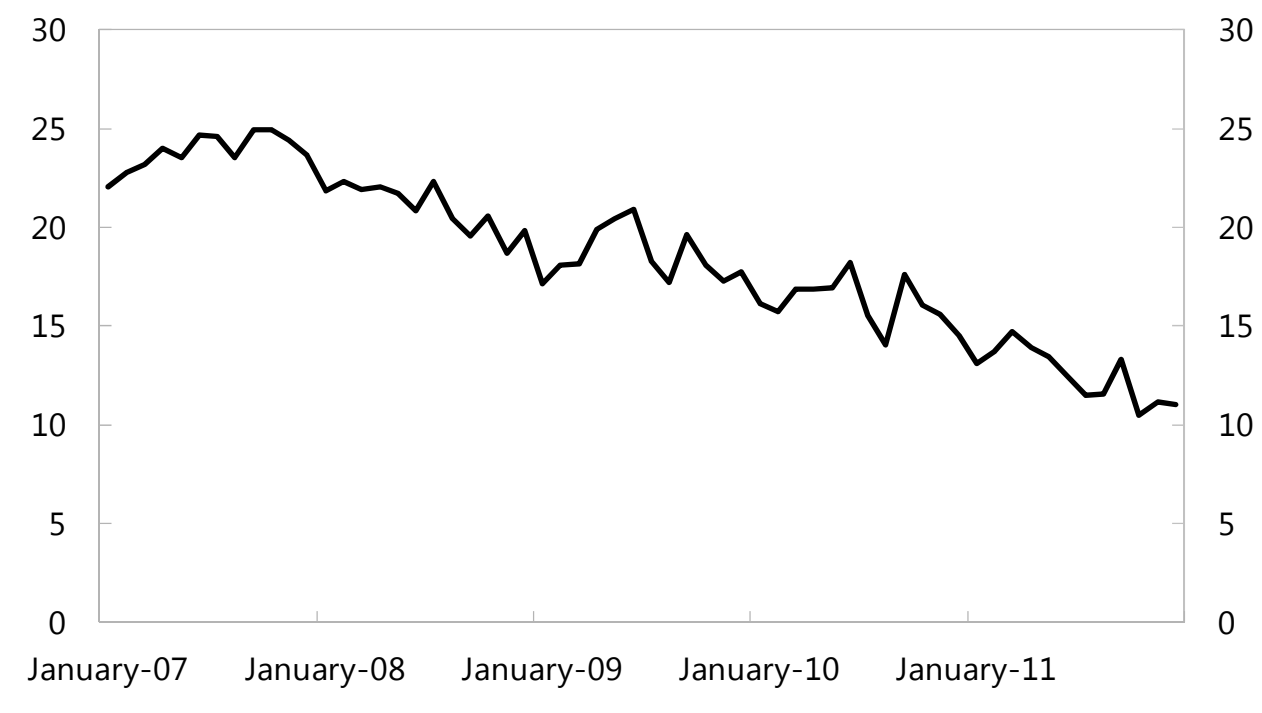

Sources: INE and IMF Staff Estimates

Figure 14. Selected Affordability Indicators
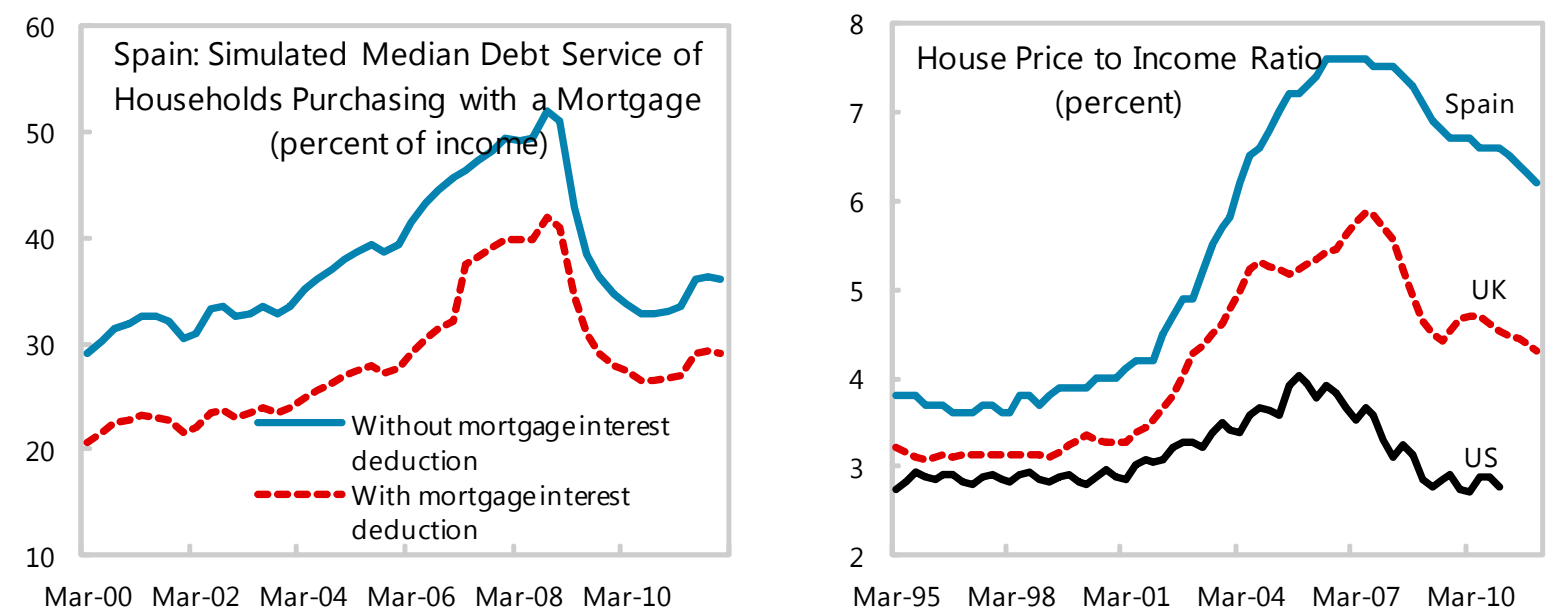

Sources: Banco de Espana; Halifax; National Association of Realtors; and US Census Bureau. 
Figure 15. Household Nonperforming Loans

Spain - Non performing loans

(In thousand euros)

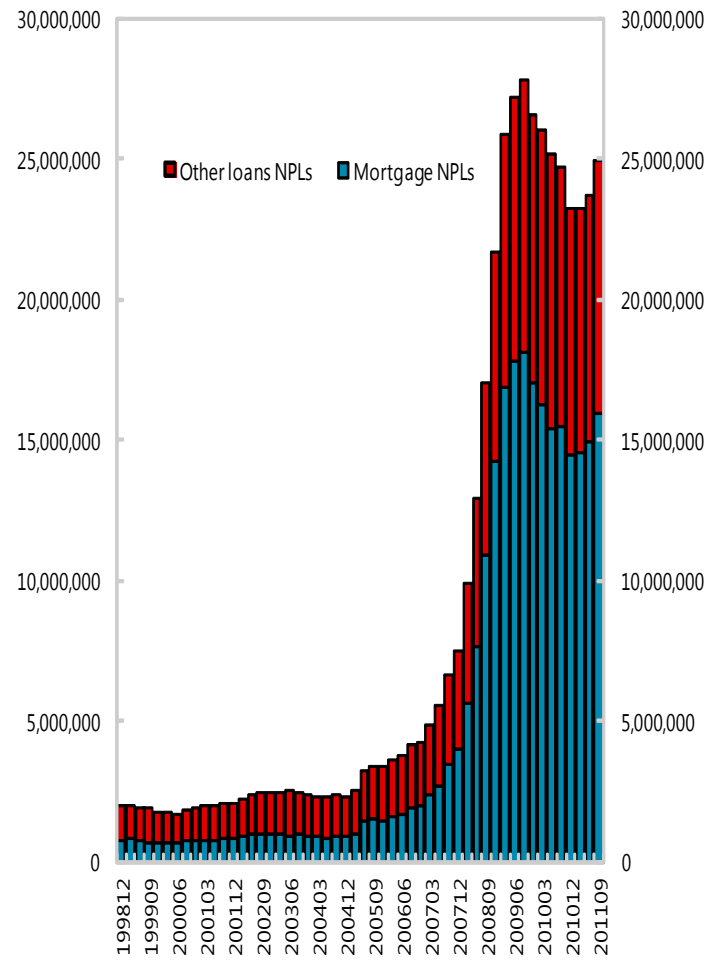

Spain - Non performing loans

(Percent change; y/y)

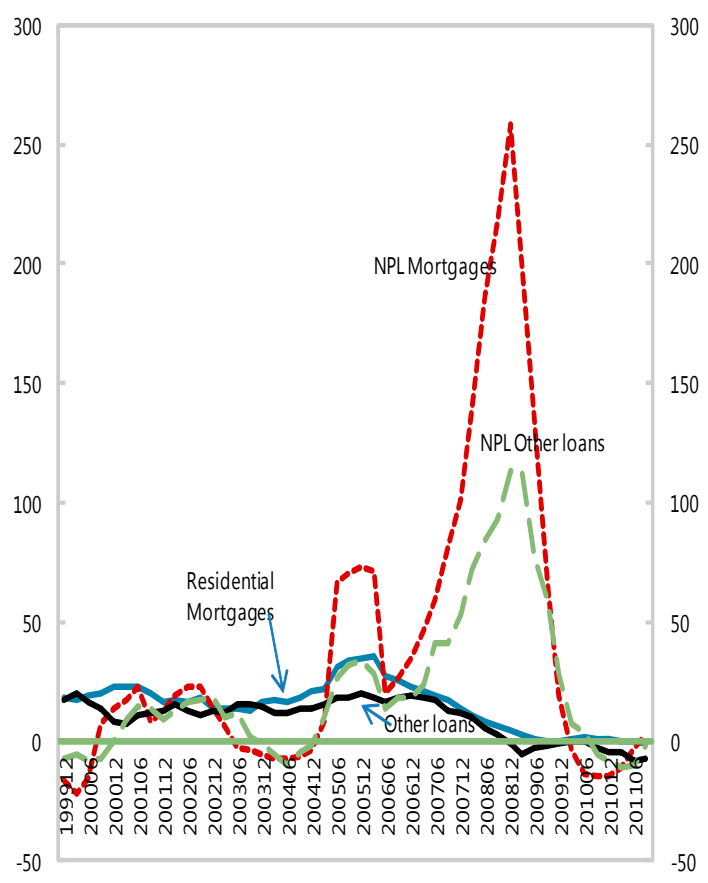

Source: Banco de Espana 
Figure 16. Household Balance Sheet Development, 2000-11

Household Debt

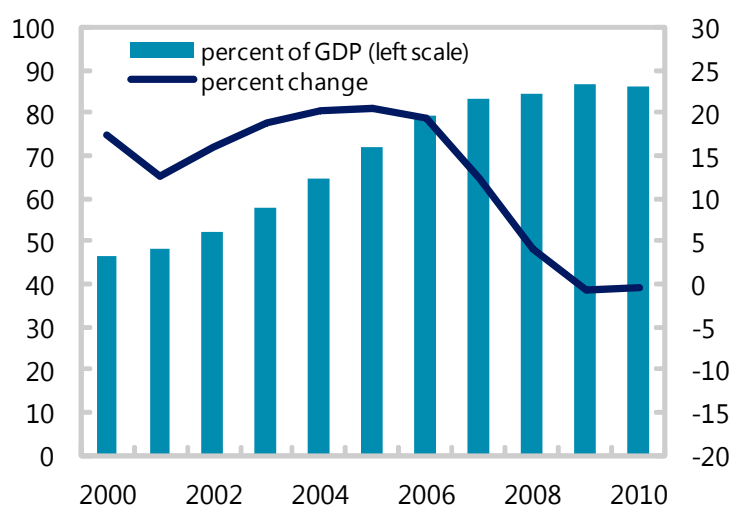

Unemployment

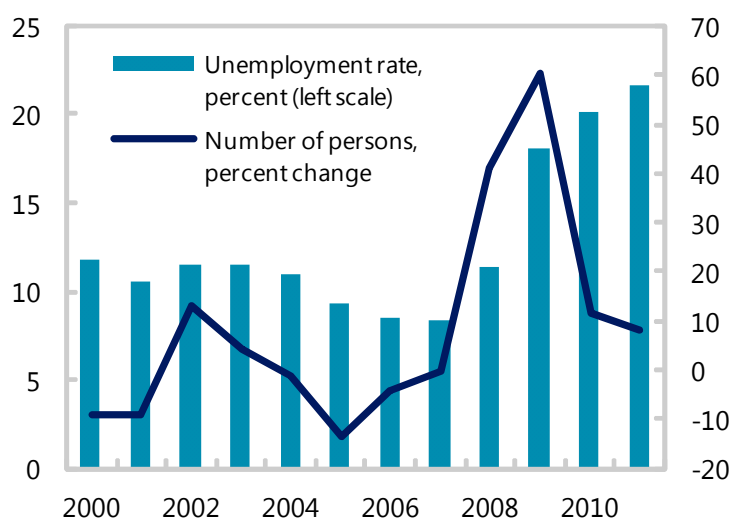

Source: Eurostat, INE, Tinsa, MVIV
Gross Disposable Income and Wage (Percent change)

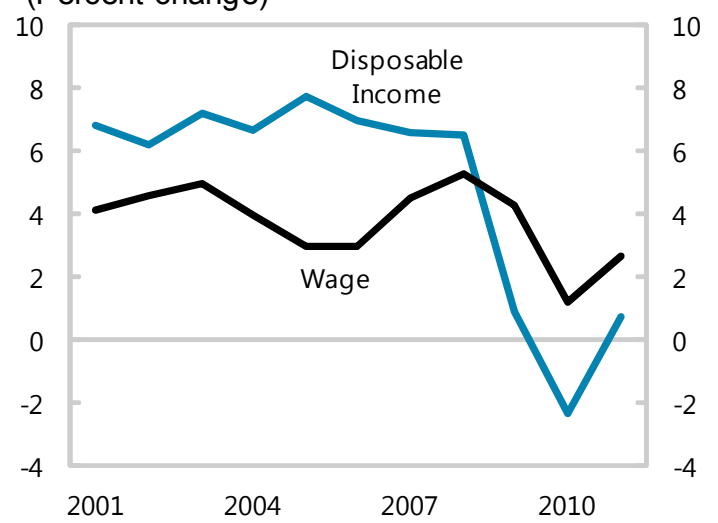

House Price

(Index, 2007=100)

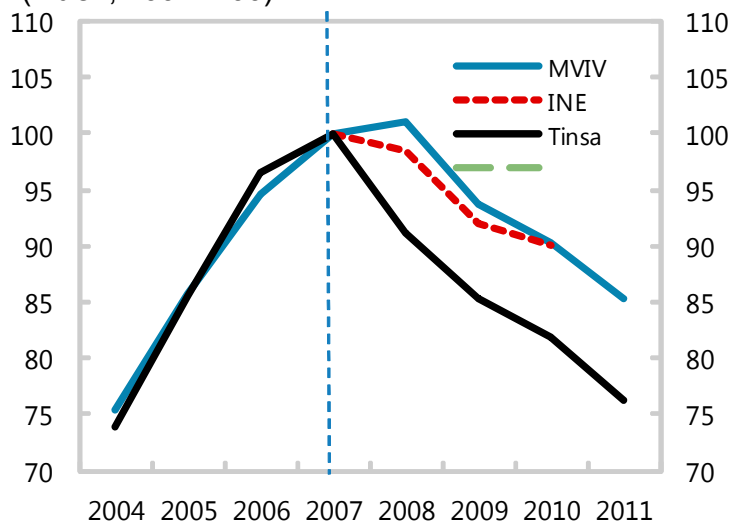


Figure 17. Distribution of Debt, Real Assets, and Financial Assets Held by Indebted Households

(Percent)

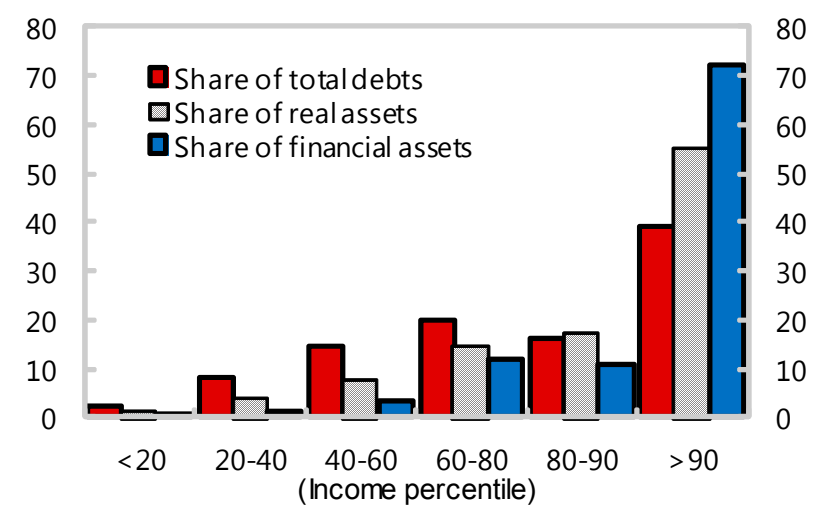

Sources: BdE, and IMF Staff Calculations.

Figure 18. Sensitivity Analysis of Indebted Households, 2008
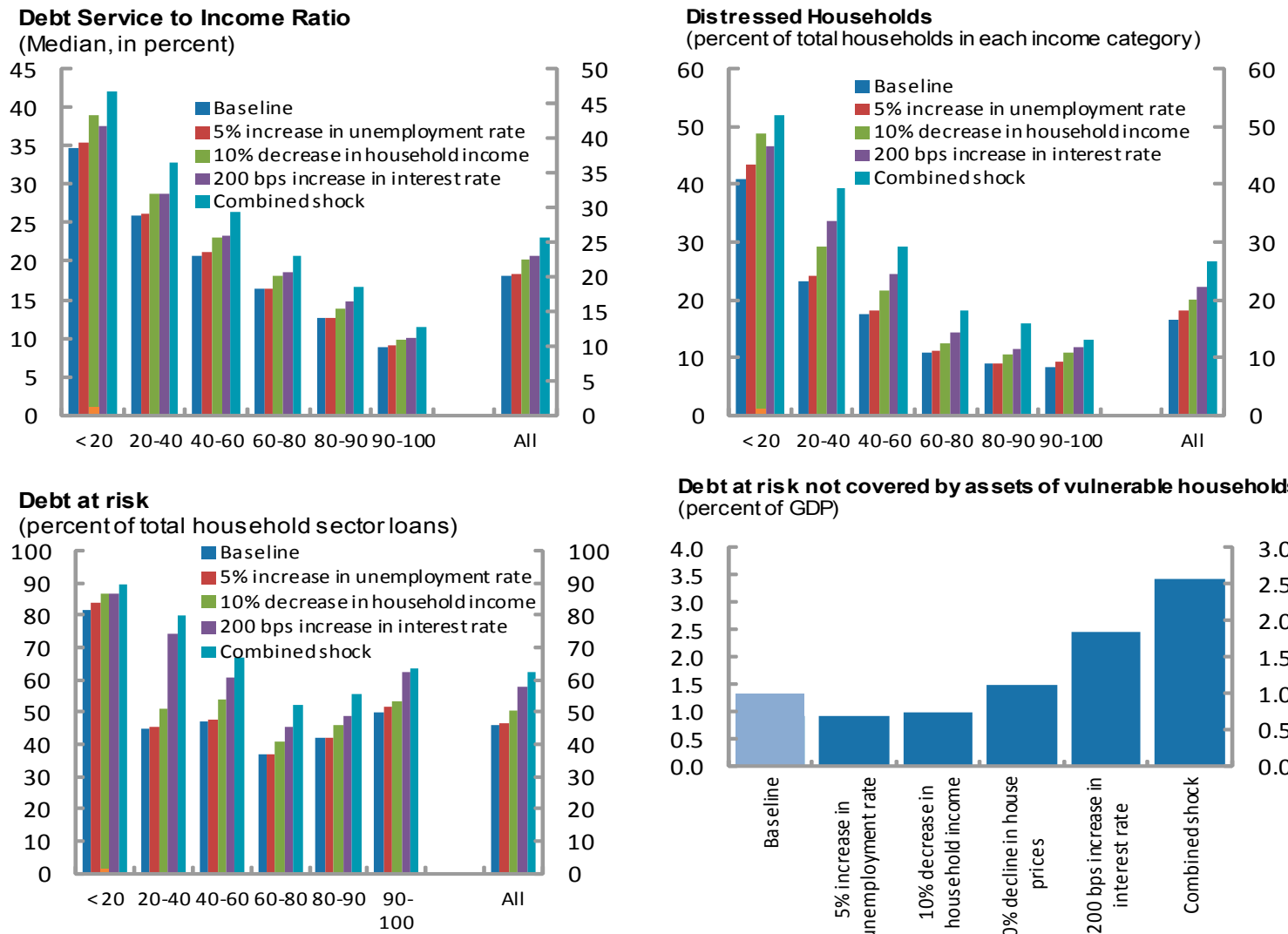

Debt at risk not covered by as sets of vulnerable households (percent of GDP)

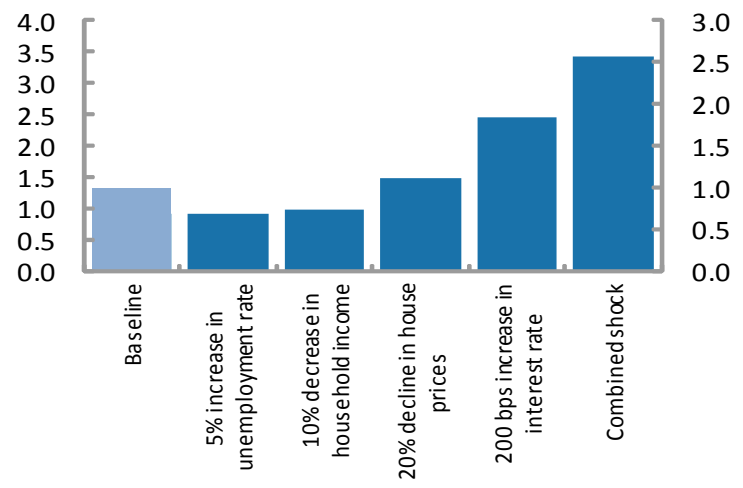

Source: IMF Staff Calculations based on Banco de España data. 
Figure 19. Sensitivity Analysis of Indebted Households, 2011
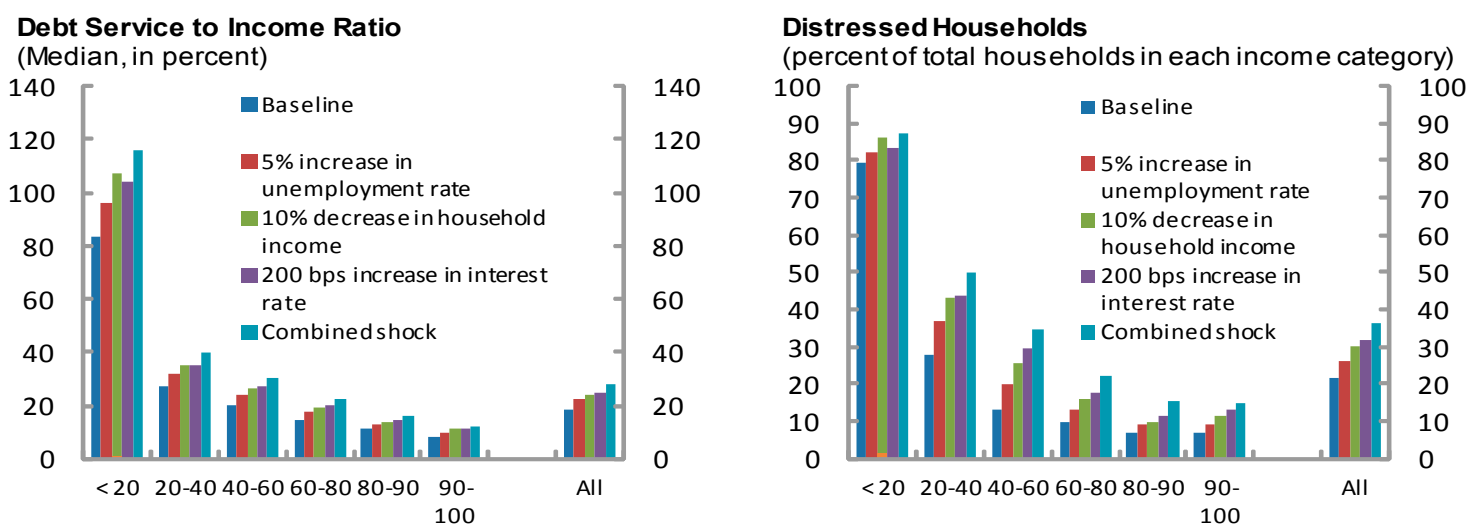

\section{Debt at risk}

(percent of total household sector loans)

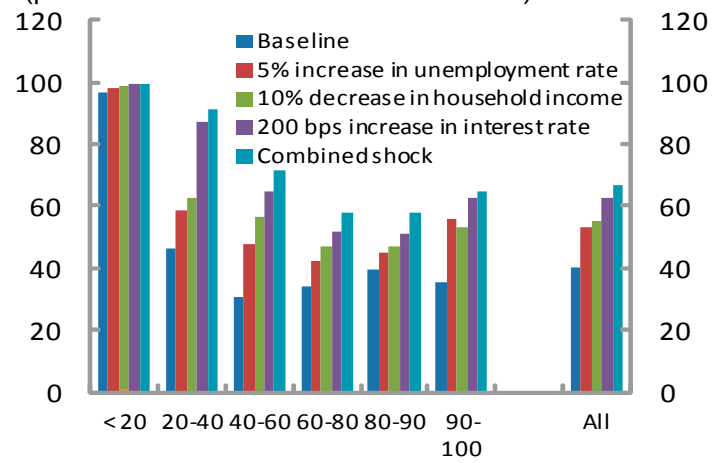

De bt at risk not covered by as sets of vulnerable households (percent of GDP)

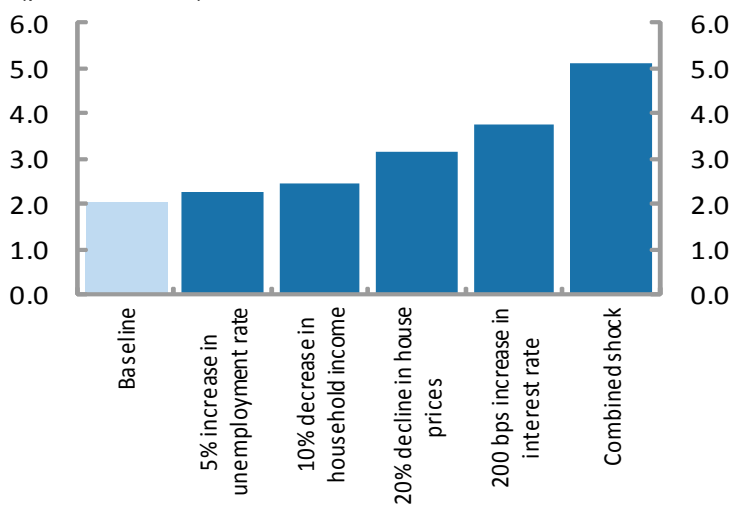

Source: IMF Staff Calculations based on Banco de España data

Figure 20. Selected Countries: Long-Term Unemployment

(In percent, 2011)

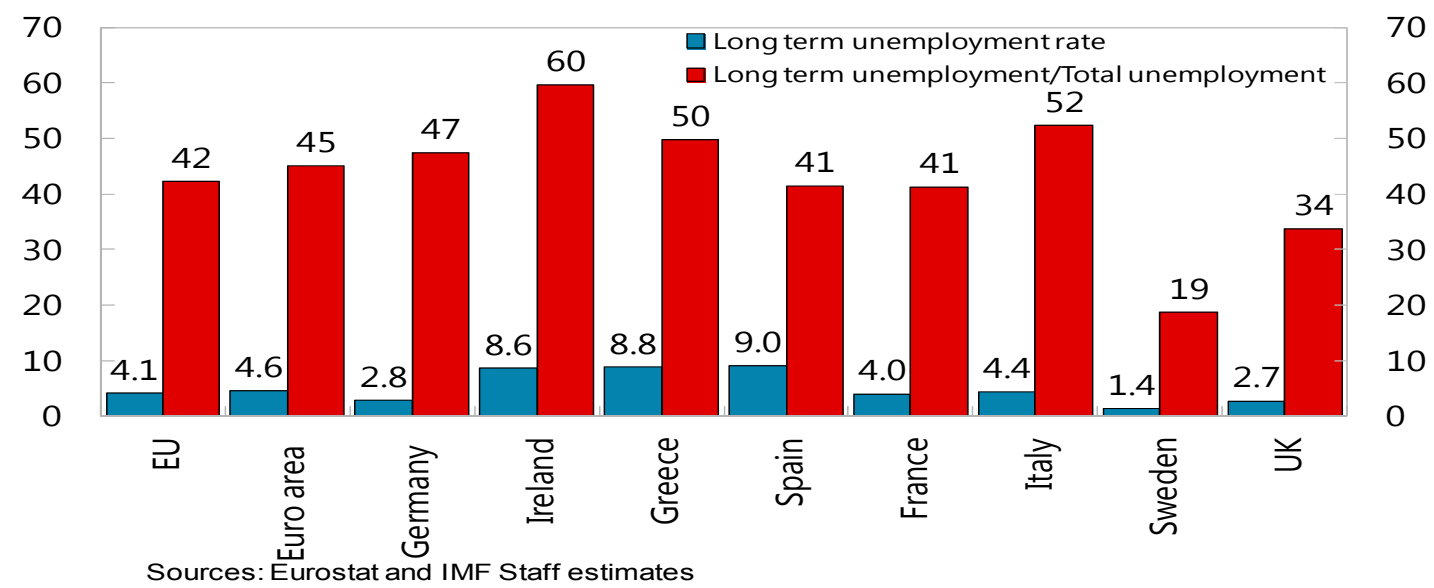


Figure 21. Selected Countries: Nonfinancial Corporate Sector Debt (In percent of GDP)

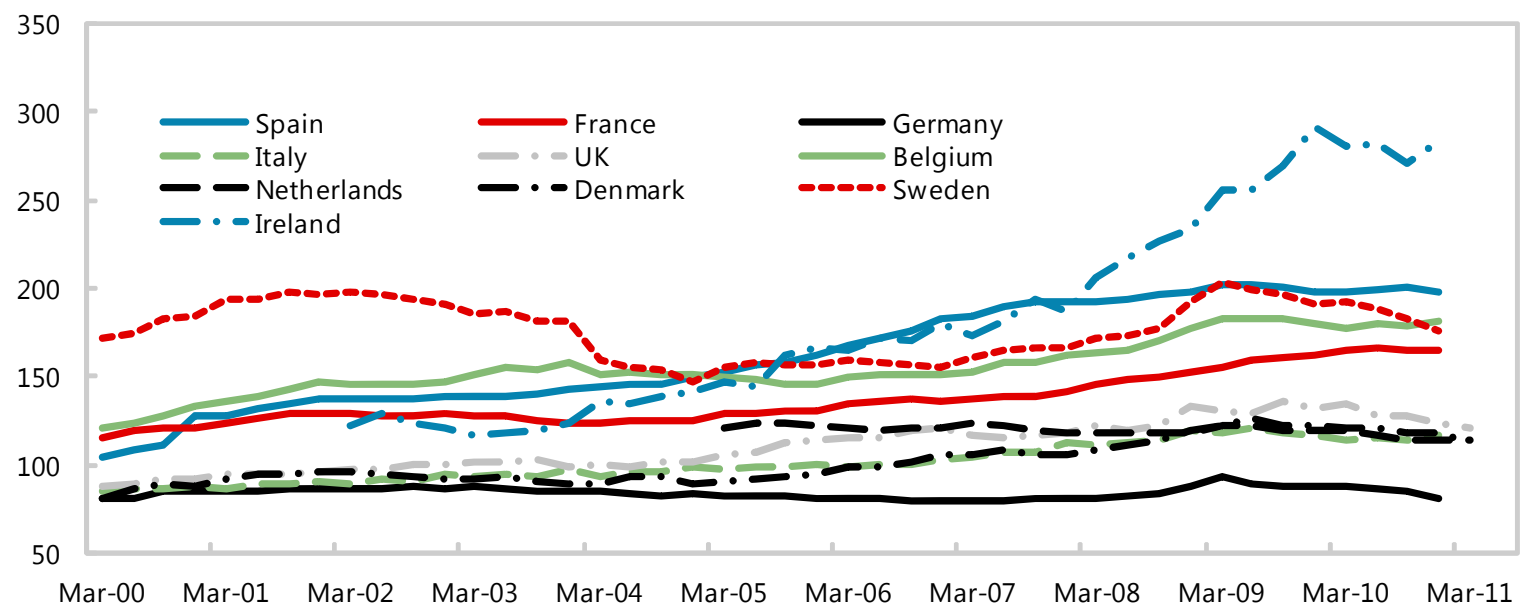

Figure 22: Spain: Credit to the Real Estate and Construction Sectors
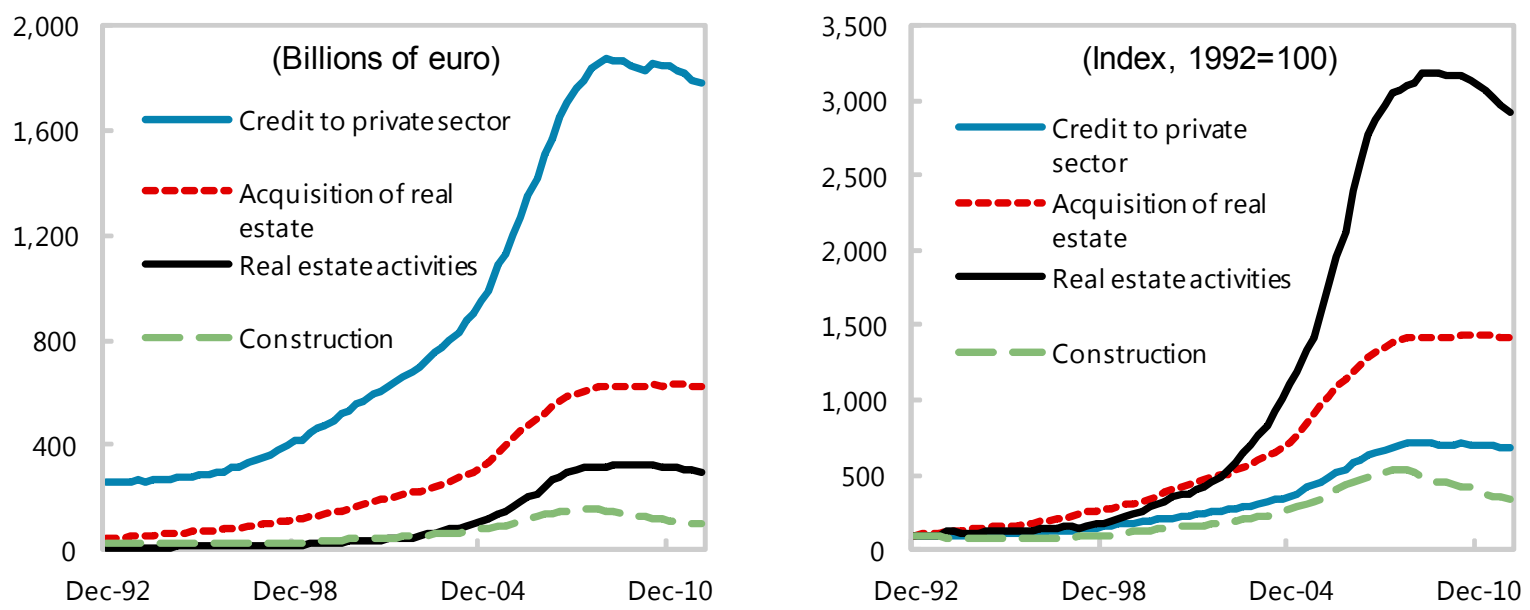

Sources: Banco de Espana; and IMF staff estimates. 
Figure 23. Financial Ratios by Sectors, Listed Companies
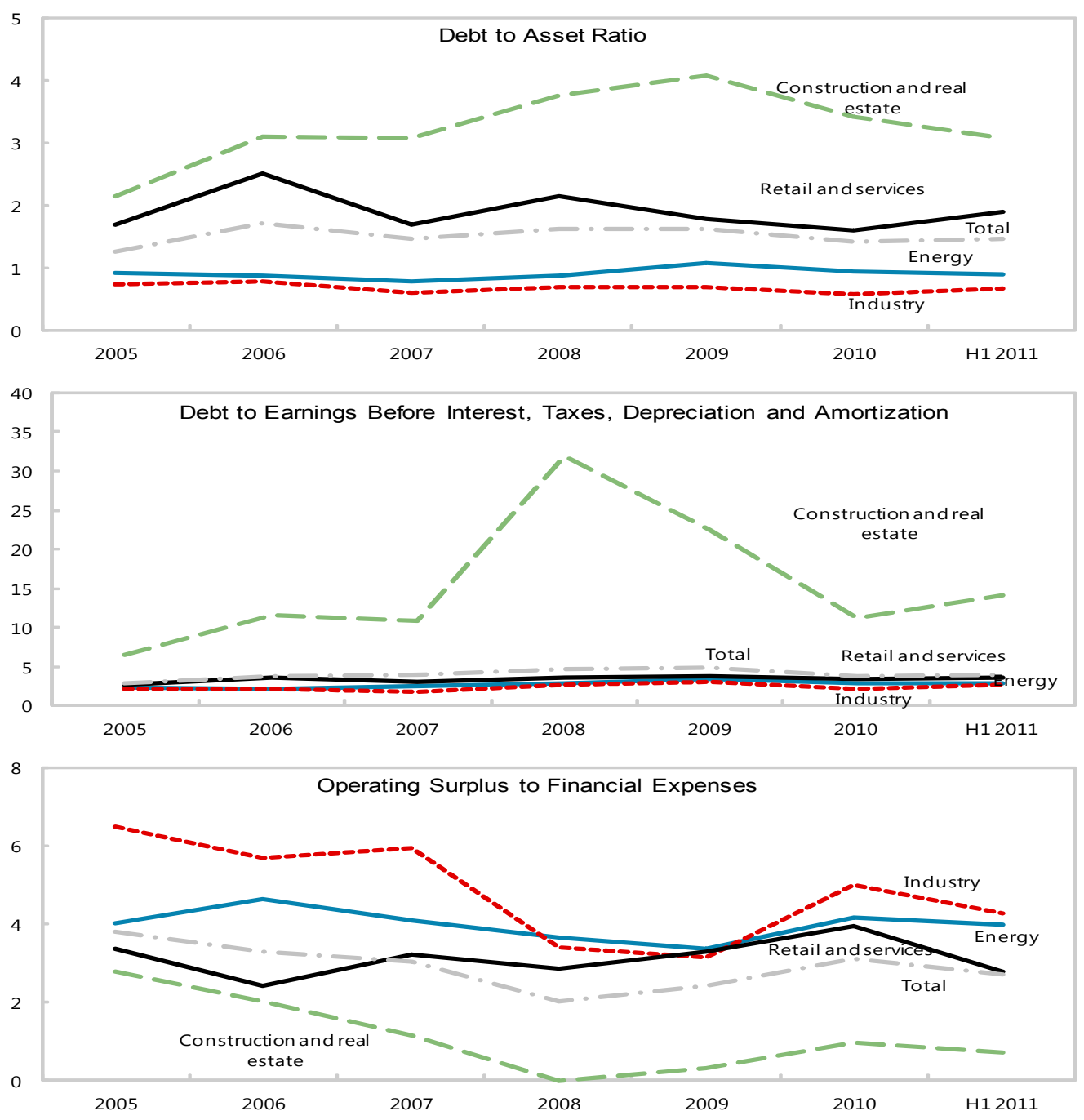

Source: Comision Nacional del Mercado de Valores (CNMV). 
Figure 24. Corporate Sector: Selected Financial Ratios
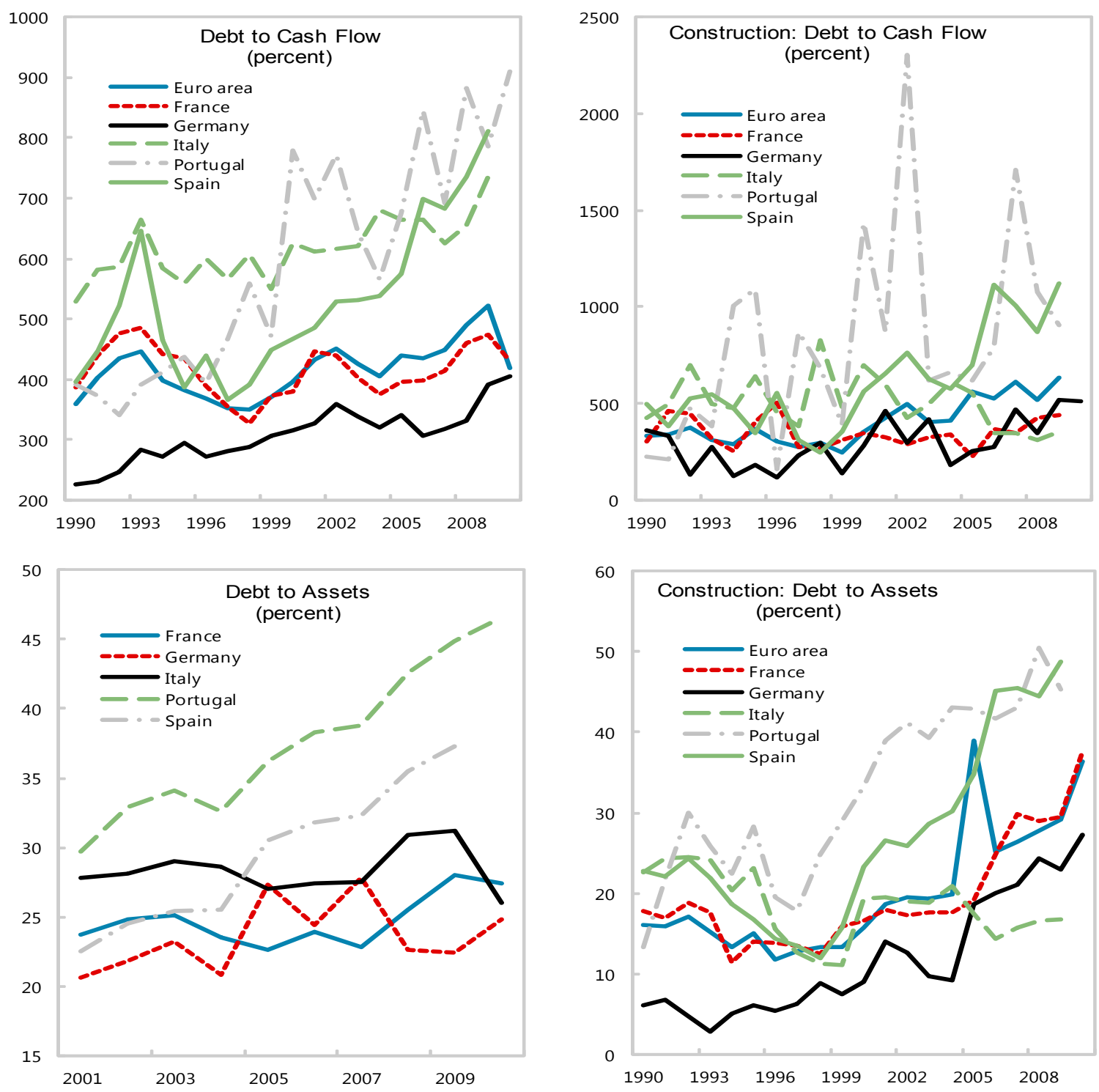

Source: IMF Corporate Sector Vulnerability Utility. 
Figure 25. Bank Debt by Sector of Activity

(In percent, 2010)
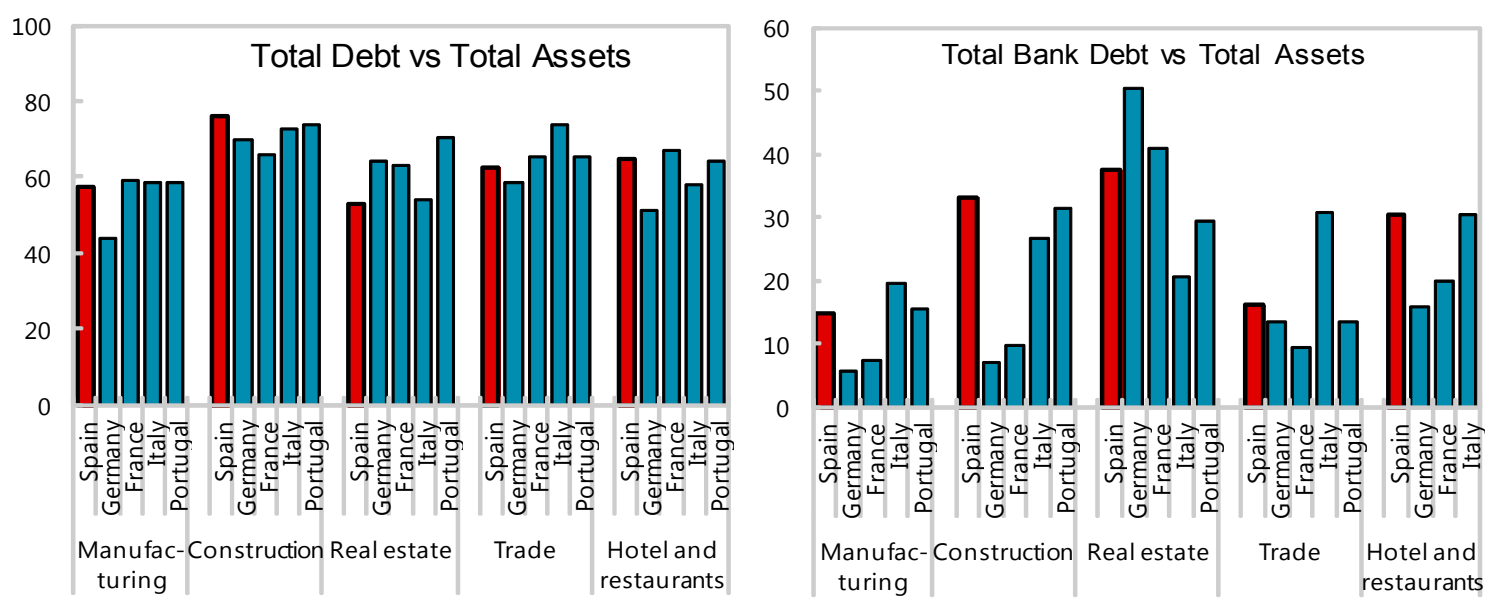

Source: BACH-ESD Database.

Figure 26. Spain: Adjustment of Credit to Real Estate and Construction (Year-on-year percent change)

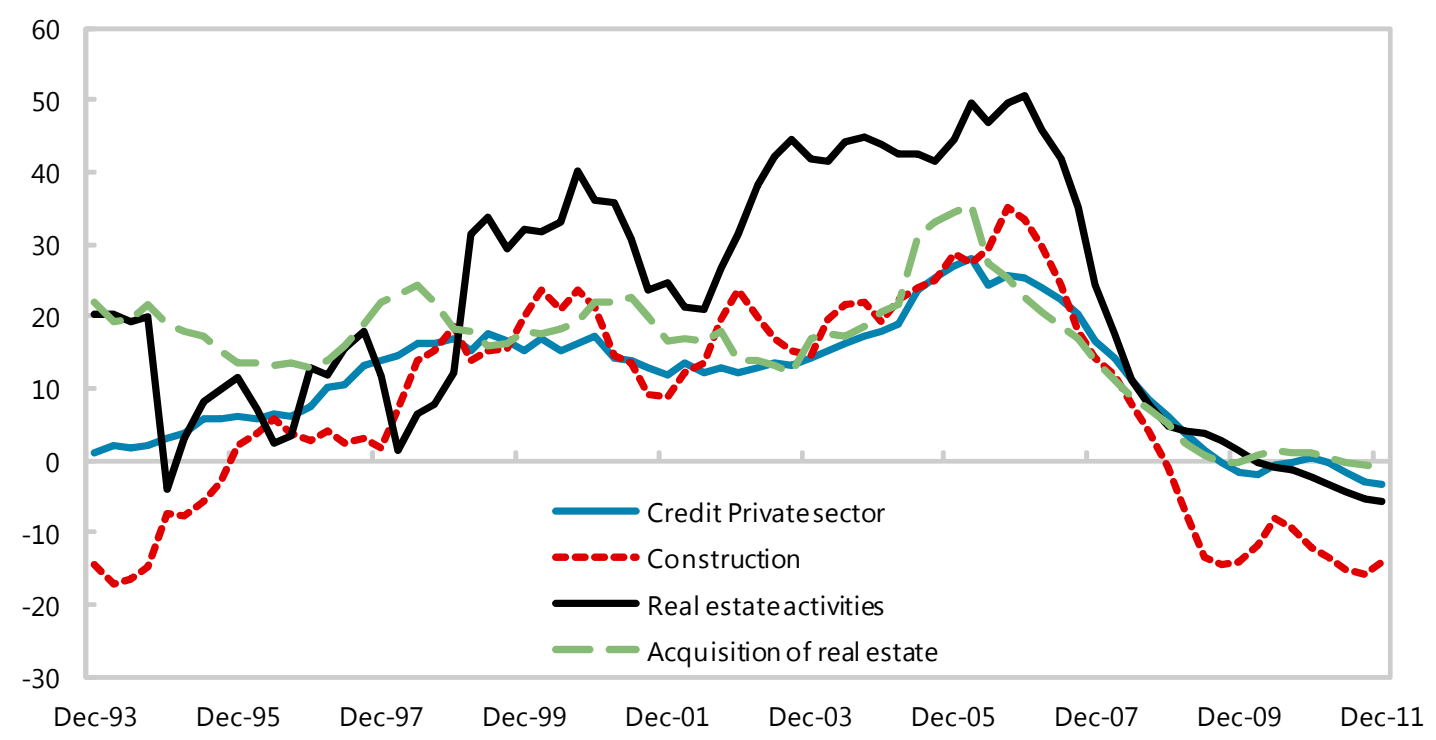


Figure 27. Spain: Rated Groups by the Bank of Spain

Largest Groups According to Their Rating (In percent)

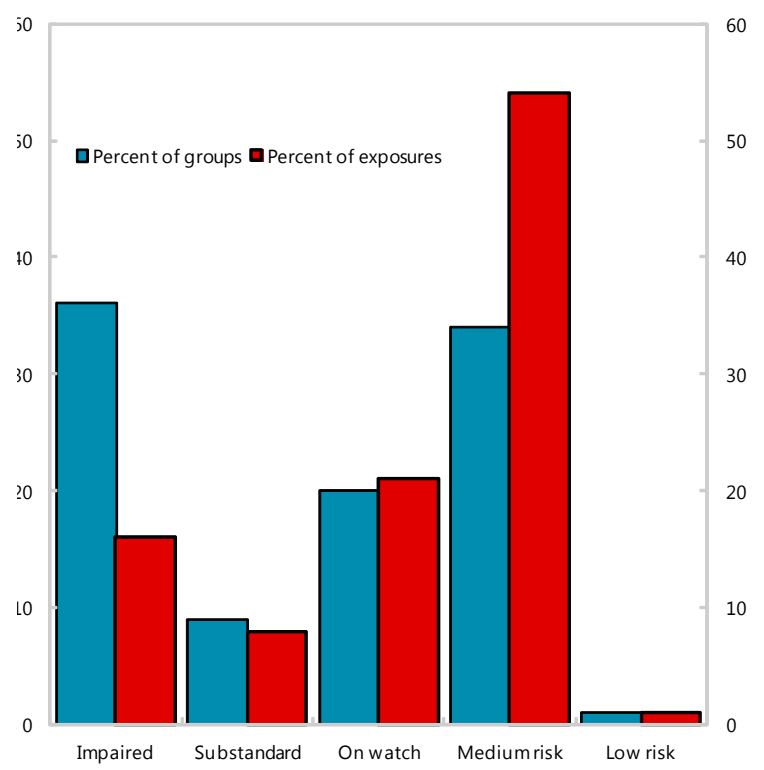

Real Estate Groups According to Their Rating (In percent)

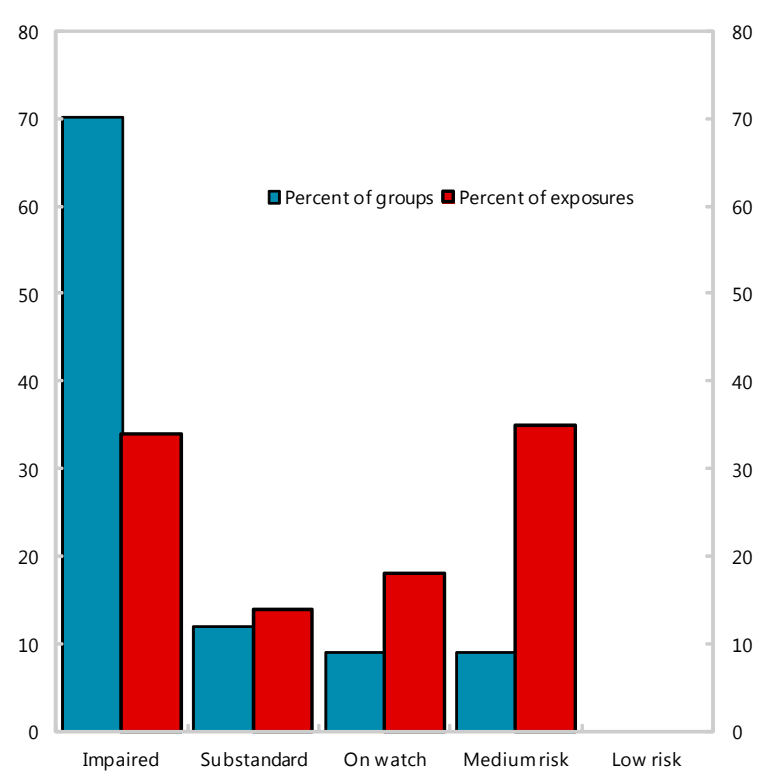

Source: Banco de Espana (SIA - Corporate Information System). 
Figure 28. Spain: Default Risks of the Spanish Nonfinancial Corporates
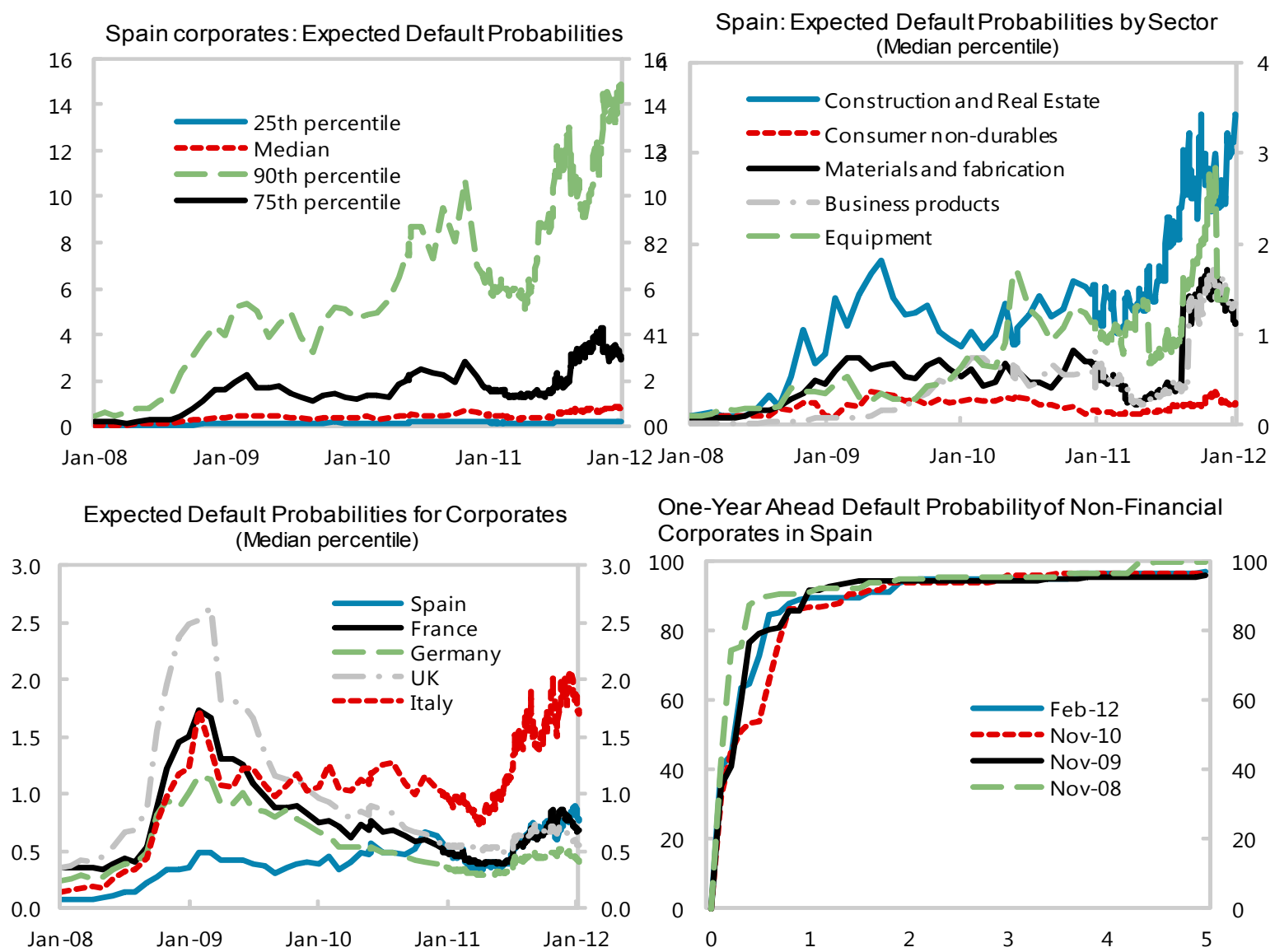

One-Year Ahead Default Probabilityof Non-Financial Corporates in Spain

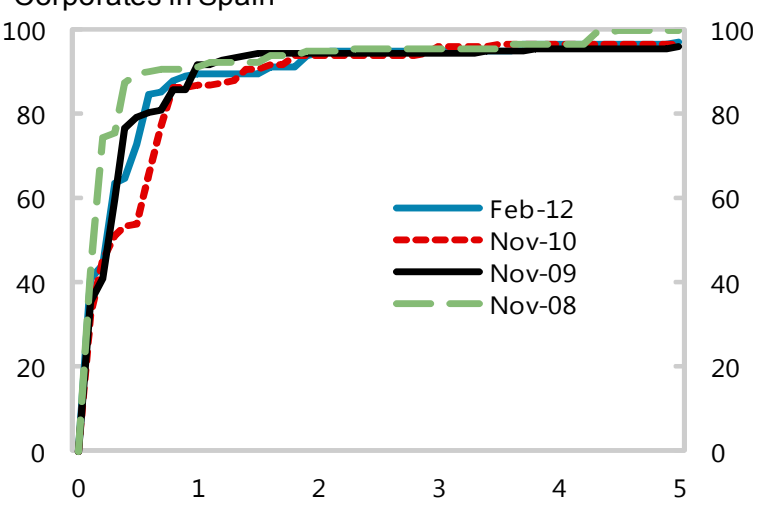

Sources: Moody's KMV, and IMF Staff Calculations.

\section{Figure 29. Spain: Contingent Claims Analysis of the Spanish Nonfinancial Corporate Sector}

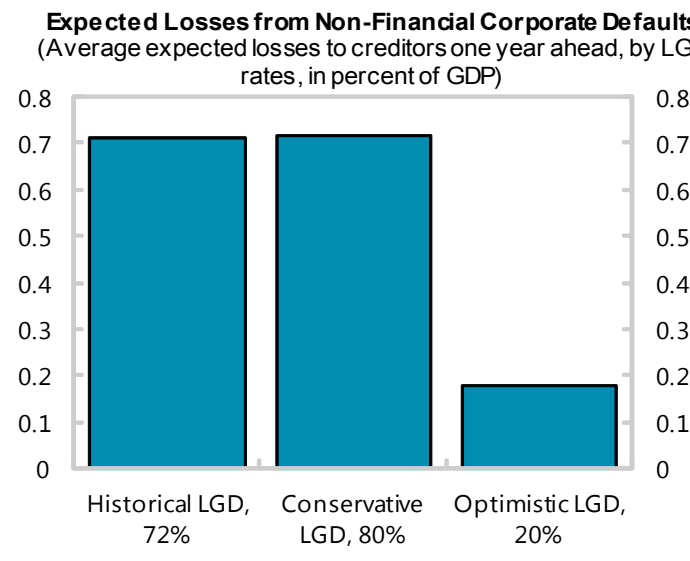

Sources: Moody's MKMV; and IMF Staff Calculations.
Expected Losses from Corporate Defaults by Sector (Percent of Total Corporate Losses, historical LGD)

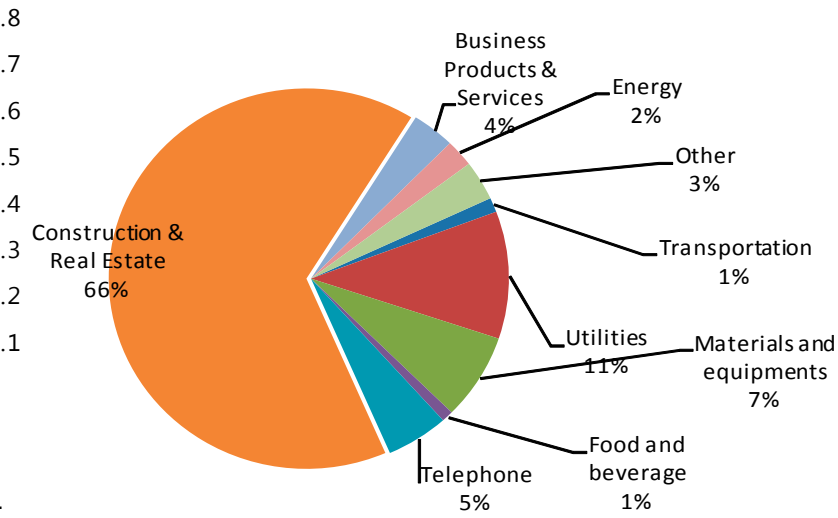


Figure 30. Corporate Debt 1/

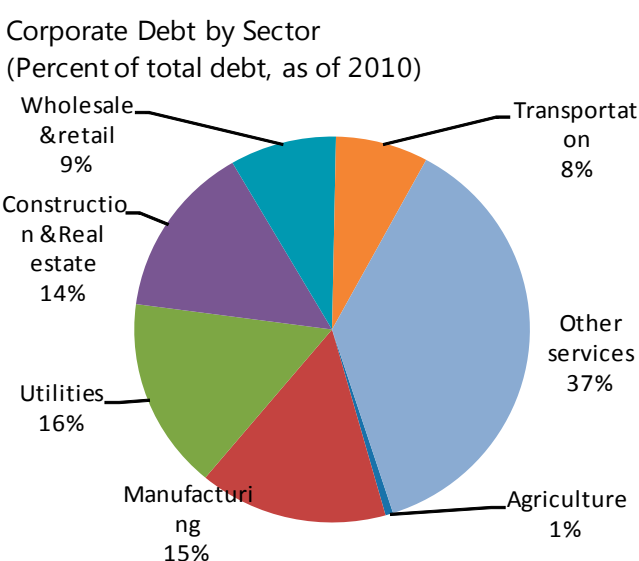

Debt-at-Risk by Sector

(Percent of total debt of the sector)

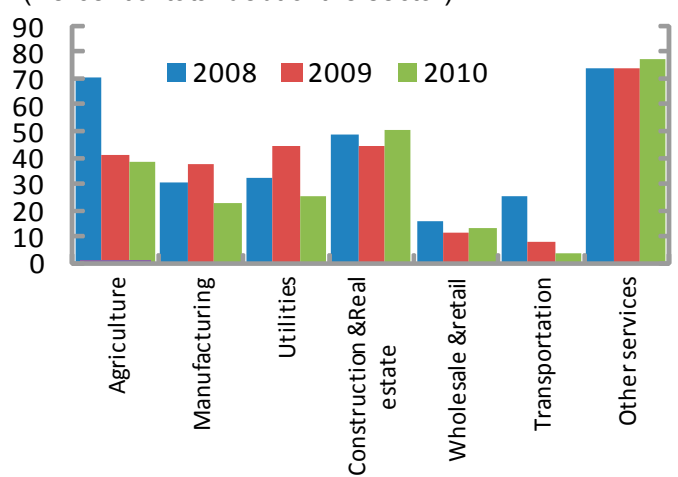

Corporate Debt by Firm Size 2/

(Percent of total debt, as of 2010)

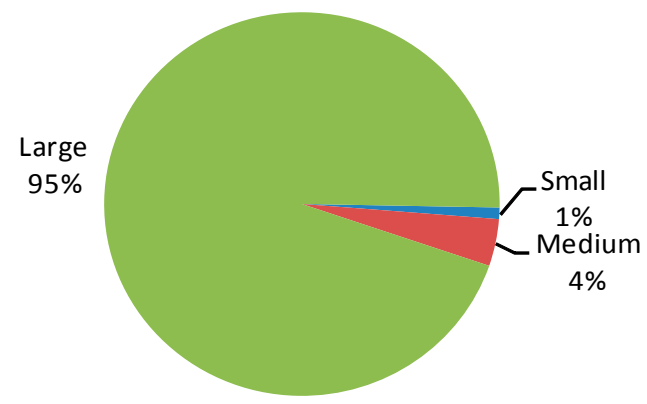

Debt-at-Risk by Firm Size 1/

(Percent of total debt in each group)

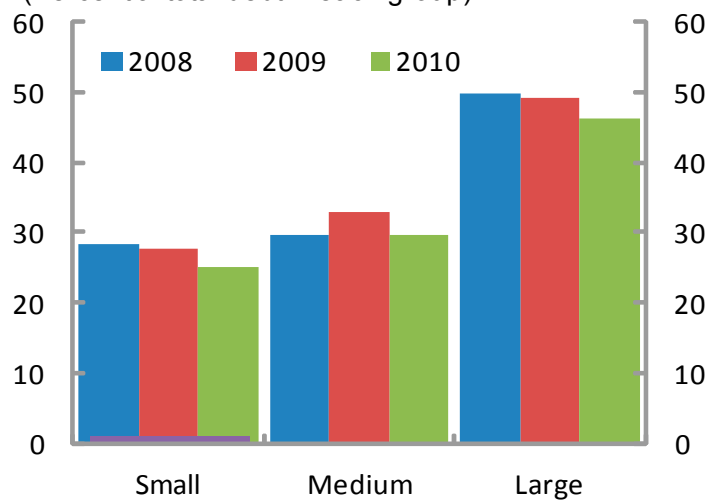

Source: IMF Staff estimates, based on BdE data.

1/ The decomposition is based on 7,041 firms from the Central de Balances data.

2/ Firm size is classified by number of employees within each firm. Small (Less than 50 employees), Medium (50-250 employees), and Large (Over 250 employees). 
Figure 31. Sensitivity Analysis of the Spanish Nonfinancial Corporate Sector
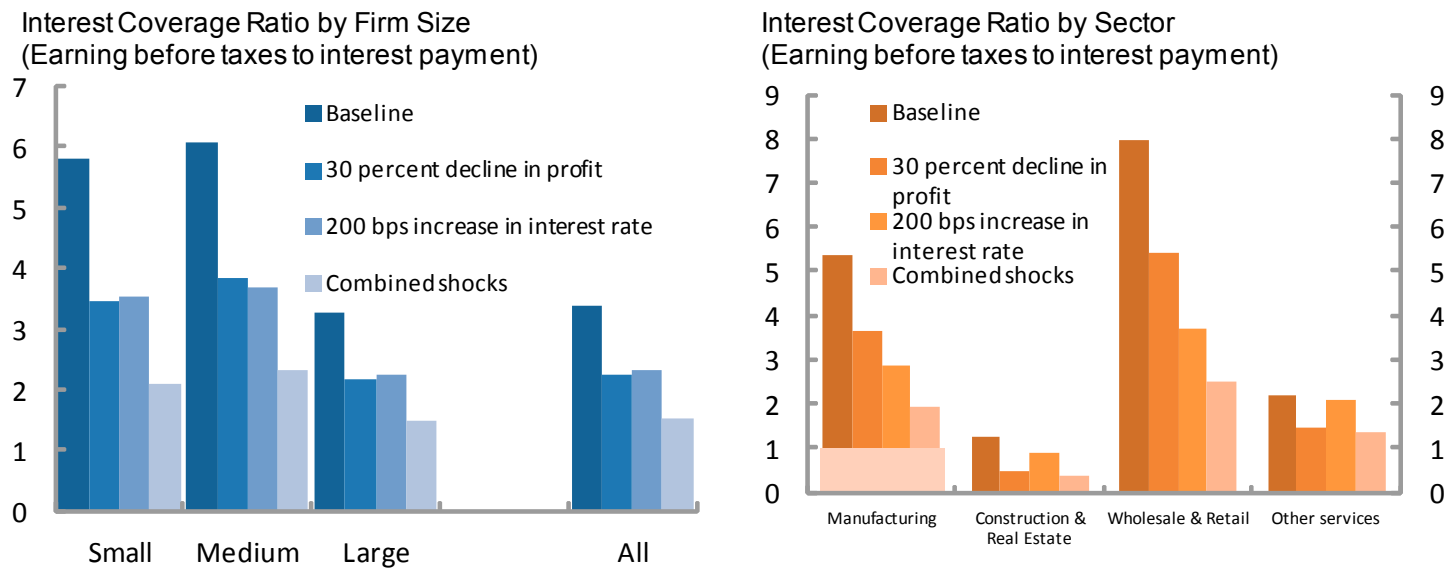

Share of Financially Distressed Firms by Firm Size (Percent of total number of firms in each group)
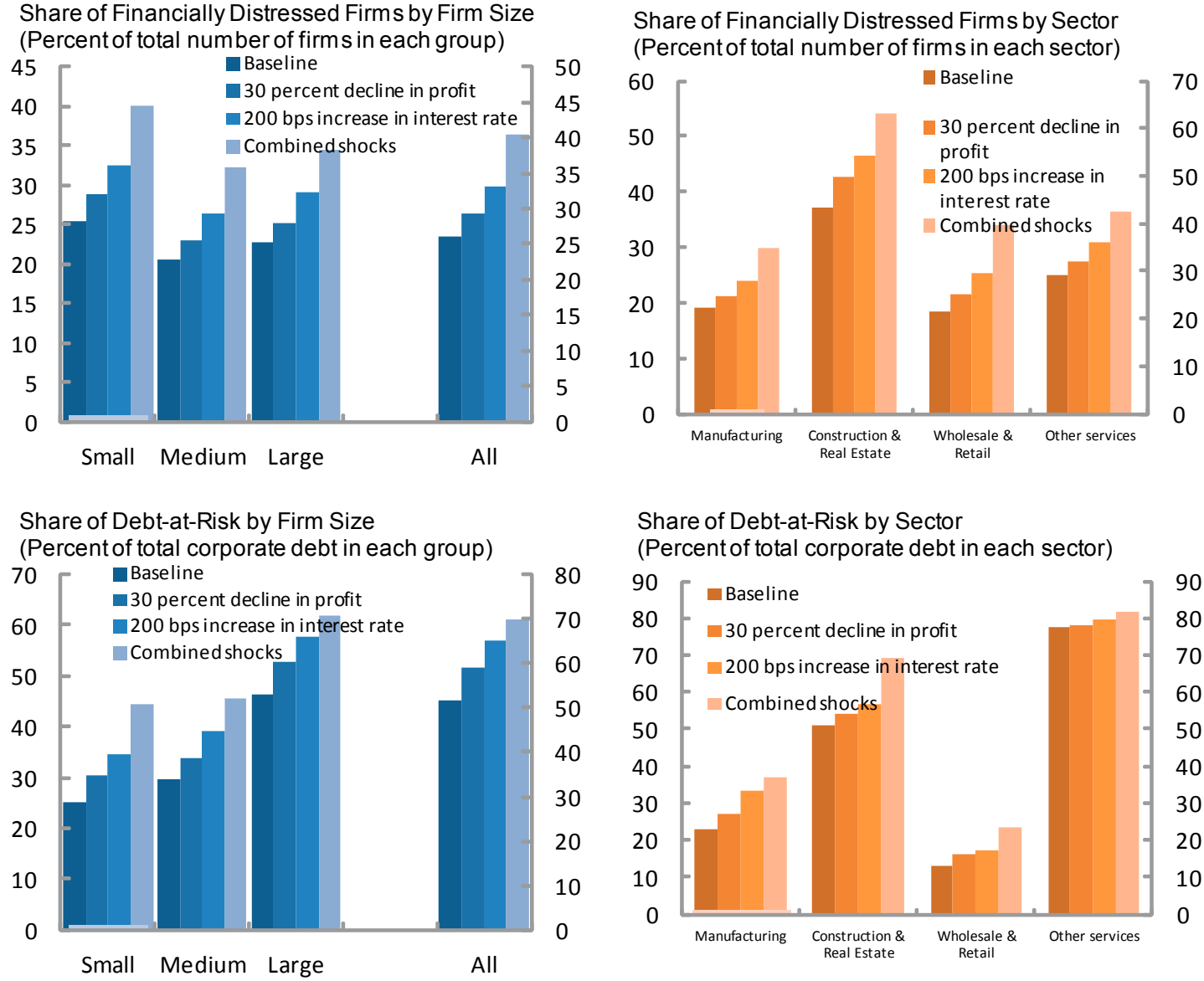

Share of Debt-at-Risk by Sector (Percent of total corporate debt in each sector)

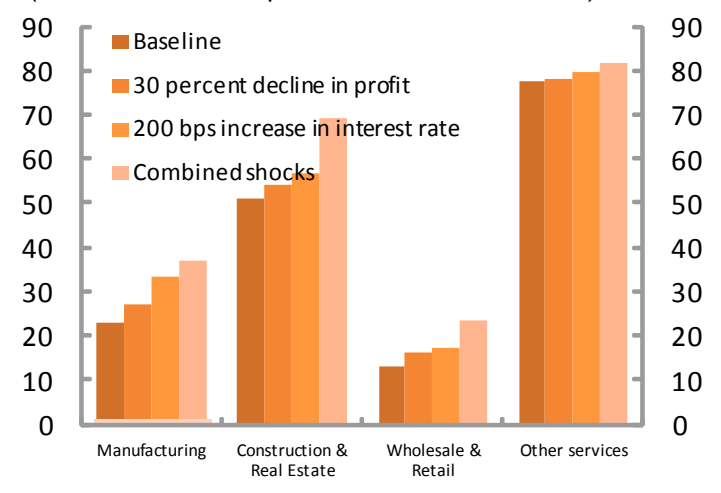

Source: IMF Staff estimates, based on BdE data. 


\section{REFERENCES}

Banco de Espana (2011a). Una actualizacion de la Situacion Patrimonial de las familias en Espana, Estados Unidos y Italia a partir de los resultados de encuestas financieras. Boletin Economico, October.

Banco de Espana (2011b).Informe Trimestral de la Economia Espanola. Boletin Economico, July-August.

Banco de Espana (2011c).Results of nonfinancial coporations in 2011 Q2. Economic Bulletin. October.

Bernal-Verdugo, L. E., Furceri, D., \& Guillaume, D. (2012). Crises, Labor Market Policy, and Unemployment. IMF Working Paper No.12-65.

Blanco, R., \& Gimeno, R. (2012). Determinants of Default Ratios in the Segment of Loans to Households in Spain. BdE's Working Paper No. 1210.

Gapen, M. T., Gray, D. F., Lim, C. H., \& Xiao, Y. (2004). The Contingent Claims Approach to Corporate Vulnerability Analysis: Estimating Default Risk and Economy-Wide Risk Transfer. IMF Working Paper No.04/121.

Gray, D., \& Marlone, S. W. (2008). Macrofinancial Risk Analysis. West Sussex: John Wiley \& Sons Ltd.

nternational Monetary Fund (IMF). (2009). Principles of Household Debt Restructuring. Staff Position Note No. 09/15.

International Monetary Fund (IMF). (2011b). How Much Has Spain's Private Sector Rebalanced? Exiting from a Credit and Housing Boom. Country Report No. 11/216.

International Monetary Fund (IMF). (2011a). Technical Note on Vulnerabilities of Household and Corporate Balance Sheets and Risks for the Financial Sector. Financial Sector Assessment Program for the United Kingdom.

Merton, R. (1974). On the Pricing of Corporate Debt: The Risk Structure of Interest Rates. Journal of Finance, 29, 449-470.

Oesterreichischen Nationalbank (OeNB). (June 2010). Stress Testing Austrian Household. Financial Stability Report, 72-91.

Riksbank. (2009). The Swedish Banks' Borrowers. Financial Stability Report, 43-74.

World Bank. (2010). The Crisis Hits Home: Stress-testing Households in Europe and Central Asia. Washington D.C.: The International Bank for Reconstruction and Development/The World Bank. 


\section{APPENDiX I. EXTRAPOLATION OF HOUSEHOLd SURVEY DATA}

50. The sensitivity analysis is based on the data from $\mathbf{2 0 0 8}$ household survey and its

extrapolation to 2011. The survey data is extrapolated to 2011 to replicate the developments of the aggregate variables from 2008 to 2011 to the extent possible. These changes include

- A 25 percent decline in house prices from 2008 to 2011. This is based on the decline of prices for second hand dwellings (INE), and is also in line with asking price data collected by private institutions (e.g., Tinsa). The survey was completed right after the peak. It was noted at the time that households valued their dwellings 7 percent less than in the previous survey (2005), but it is also possible that the 2005 survey overestimated house prices.

- A 10 percent increase in the unemployment rate in the sample is generated to reflect an increase in the actual unemployment rate to 21.6 percent in 2011 , from 11.3 percent in 2008. The new unemployed persons will receive the unemployment insurance benefits of 70 percent of their previous earnings.

- $\quad$ The unemployment insurance benefits of unemployed persons in 2008 are assumed to expire in 2011 and these persons will receive only the monthly allowance of $€ 400$ per month.

- A decline in interest rate of about 200 basis points was applied to the interest payment for all households. 


\section{Appendix II. Household Debt Restructuring in Selected Countries}

\begin{tabular}{|c|c|c|c|c|}
\hline Country & Program & Beneficiaries & $\begin{array}{c}\text { Debt } \\
\text { Modifications }\end{array}$ & $\begin{array}{l}\text { Incentives and Burden } \\
\text { Sharing }\end{array}$ \\
\hline \multirow[t]{4}{*}{$\begin{array}{l}\text { Iceland } \\
2008\end{array}$} & $\begin{array}{l}\text { (i)Payment } \\
\text { smoothing }\end{array}$ & $\begin{array}{l}\text { Households with } \\
\text { CPI-linked and FX- } \\
\text { linked mortgages } \\
\text { and car loans }\end{array}$ & $\begin{array}{l}\text { Debt service } \\
\text { reduced through } \\
\text { rescheduling and } \\
\text { maturity extension }\end{array}$ & $\begin{array}{l}\text { (i) CPI-mortgages: Statutory } \\
\text { requirement. } \\
\text { (ii) FX-linked loans: Agreement } \\
\text { between government and } \\
\text { lenders }\end{array}$ \\
\hline & $\begin{array}{l}\text { (ii) Sector } \\
\text { agreement } \\
\text { (Bank } \\
\text { administered } \\
\text { voluntary } \\
\text { restructuring) }\end{array}$ & $\begin{array}{l}\text { Households with } \\
\text { multiple creditors } \\
\text { and debt service } \\
\text { difficulties but able } \\
\text { to service a } \\
\text { mortgage } \\
\text { amounting to at } \\
\text { least } 70 \text { percent of } \\
\text { the value of the } \\
\text { house. }\end{array}$ & $\begin{array}{l}\text { (i) Debt service } \\
\text { scaled down to } \\
\text { capacity to pay } \\
\text { (ii) Debt reduced to } \\
100 \text { percent of } \\
\text { collateral value if } \\
\text { households remain } \\
\text { current on reduced } \\
\text { payments for } 3 \\
\text { years }\end{array}$ & $\begin{array}{l}\text { (i) Government fostered } \\
\text { agreement among largest } \\
\text { lenders. } \\
\text { (ii) Participation was voluntary. } \\
\text { (iii) If agreement is not } \\
\text { reached, debtors may apply to } \\
\text { the Debtor's Ombudsman or } \\
\text { the courts. } \\
\text { (iv) The burden of restructuring } \\
\text { the loans falls on the lenders }\end{array}$ \\
\hline & $\begin{array}{l}\text { (iii) Debtors' } \\
\text { Ombudsman } \\
\text { (DO } \\
\text { Administered } \\
\text { Voluntary } \\
\text { Restructuring) }\end{array}$ & $\begin{array}{l}\text { Similar to Sector } \\
\text { Agreement but } \\
\text { reaches less } \\
\text { wealthy } \\
\text { households. Aimed } \\
\text { at households } \\
\text { seeking advice and } \\
\text { support in dealing } \\
\text { with creditors. }\end{array}$ & $\begin{array}{l}\text { Similar to Sector } \\
\text { Agreement but } \\
\text { allows deeper } \\
\text { temporary } \\
\text { reduction in debt } \\
\text { service. } \\
\text { Procedures are } \\
\text { more tailored and } \\
\text { complex than } \\
\text { under Sector } \\
\text { Agreement. }\end{array}$ & $\begin{array}{l}\text { (i) Statutory framework which } \\
\text { leads to court administered } \\
\text { restructuring in the event that } \\
\text { negotiations are unsuccessful. } \\
\text { (ii) The burden of restructuring } \\
\text { the loans falls on the lenders. }\end{array}$ \\
\hline & $\begin{array}{l}\text { (iv) Mortgage } \\
\text { write-down for } \\
\text { deeply } \\
\text { underwater } \\
\text { households }\end{array}$ & $\begin{array}{l}\text { Households with } \\
\text { LTV above } 110 \\
\text { percent as of Dec } \\
2010\end{array}$ & $\begin{array}{l}\text { Principal reduced } \\
\text { to } 110 \text { percent of } \\
\text { the value of the } \\
\text { debtor's pledgeable } \\
\text { assets and every } \\
\text { mortgage holder } \\
\text { received a sizeable } \\
\text { interest rate } \\
\text { subsidy over a } 2 \\
\text { year period, } \\
\text { financed through } \\
\text { temporary levies on } \\
\text { the financial sector }\end{array}$ & $\begin{array}{l}\text { (i) Agreement between } \\
\text { mortgage lenders and } \\
\text { government. Participation was } \\
\text { voluntary but lenders signed on } \\
\text { because the written-down } \\
\text { value exceeded the recovery } \\
\text { likely through bankruptcy. } \\
\text { (ii) Moral hazard avoided as } \\
\text { program limited to those above } \\
110 \text { percent LTV in Dec } 2010 \\
\text { (iii) The burden of restructuring } \\
\text { the loans falls on the lenders. }\end{array}$ \\
\hline $\begin{array}{l}\text { United } \\
\text { States } \\
2009\end{array}$ & $\begin{array}{l}\text { Home } \\
\text { Affordable } \\
\text { Modification } \\
\text { Program } \\
\text { (HAMP) }\end{array}$ & $\begin{array}{l}\text { Households in } \\
\text { default }\end{array}$ & $\begin{array}{l}\text { Focused on } \\
\text { reducing } \\
\text { repayment burdens } \\
\text { through interest } \\
\text { rate reductions and } \\
\text { etc. }\end{array}$ & $\begin{array}{l}\text { (i) Participation in voluntary } \\
\text { except for receivers of TARP } \\
\text { funds } \\
\text { (ii) Lenders are rarely required } \\
\text { to take principal write-offs, } \\
\text { increasing the likelihood that } \\
\text { the modified loan will re-default } \\
\text { (iii) Restructuring is initiated by } \\
\text { servicers (not lenders) who }\end{array}$ \\
\hline
\end{tabular}




\begin{tabular}{|l|l|l|l|l|}
\hline Country & Program & Beneficiaries & \multicolumn{1}{|c|}{$\begin{array}{c}\text { Debt } \\
\text { Modifications }\end{array}$} & \multicolumn{1}{|c|}{$\begin{array}{c}\text { Incentives and Burden } \\
\text { Sharing }\end{array}$} \\
\hline & & & & $\begin{array}{l}\text { have very small financial } \\
\text { incentive to participate. } \\
\text { (iv) Securitization and junior- } \\
\text { claim holders create conflicts of } \\
\text { interest and exacerbate } \\
\text { asymmetric information costs }\end{array}$ \\
\hline $\begin{array}{l}\text { Hungary } \\
\mathbf{2 0 1 1}\end{array}$ & $\begin{array}{l}\text { September } \\
2011\end{array}$ & $\begin{array}{l}\text { Borrowers in good } \\
\text { standing with FX- } \\
\text { denominated } \\
\text { mortgages }\end{array}$ & $\begin{array}{l}\text { Principal write- } \\
\text { down through the } \\
\text { ability to prepay } \\
\text { mortgages at a } \\
\text { preferential } \\
\text { exchange rate }\end{array}$ & $\begin{array}{l}\text { (i) Mandated by statute } \\
\text { (ii) Burden of write-down borne } \\
\text { by lenders alone } \\
\text { (iii) Prepayment requirement } \\
\text { limits ability of borrowers to } \\
\text { participate }\end{array}$ \\
\hline
\end{tabular}

Source: World Economic Outlook, Spring 2012. 